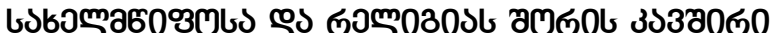

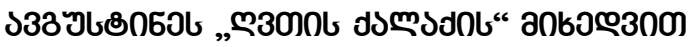

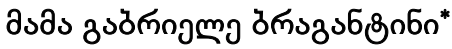

\section{I. วglsзsмmo}

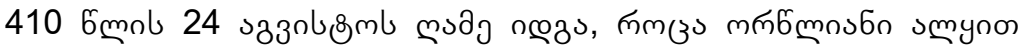

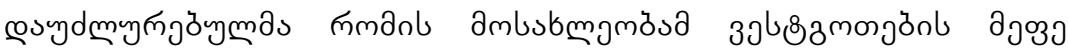

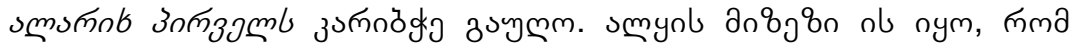

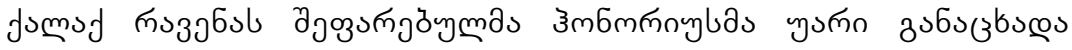

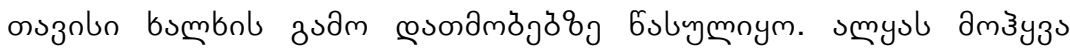

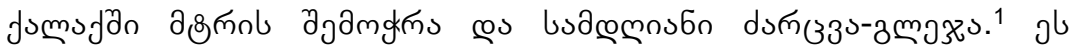

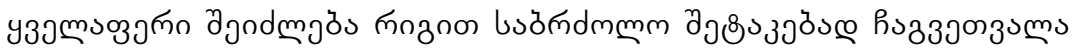

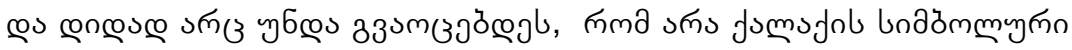

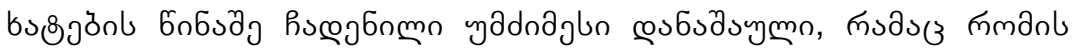

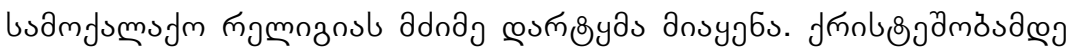

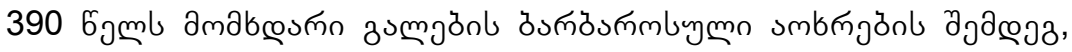

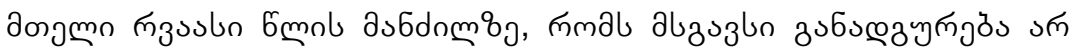

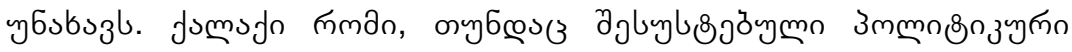

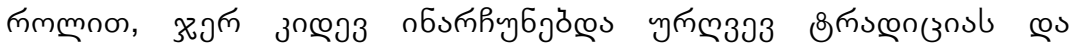

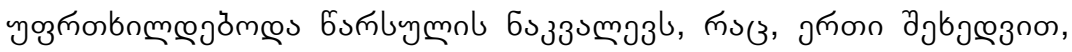

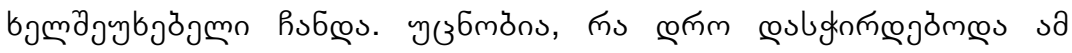

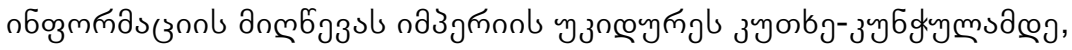

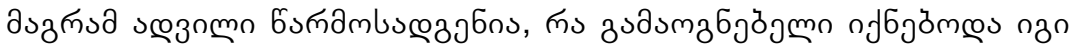

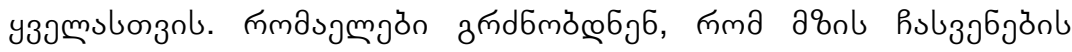

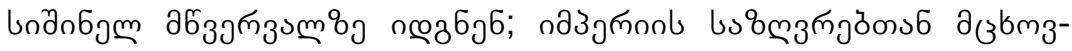

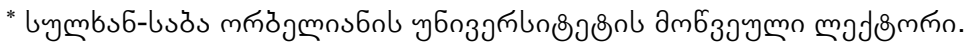

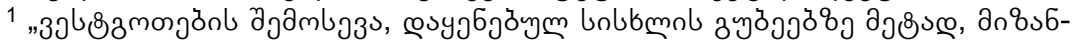

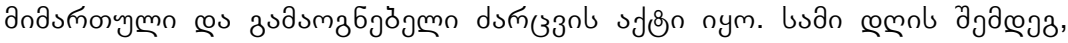

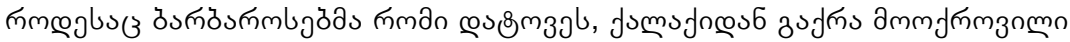

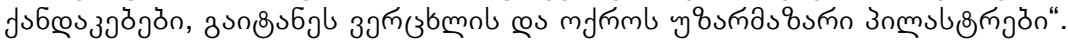
jə১œ. Brown P., Per la cruna di un ago. La ricchezza, la caduta di Roma e lo sviluppo del cristianesimo, 350-550 d.C., Einaudi, Torino, 2014, 409.
} 


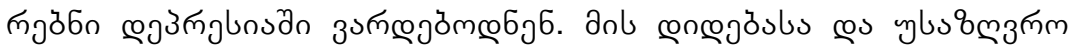

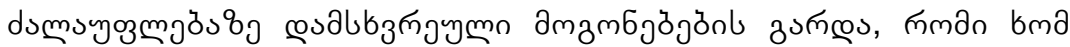

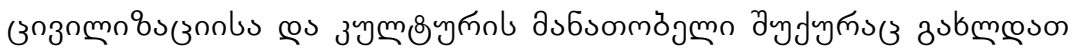

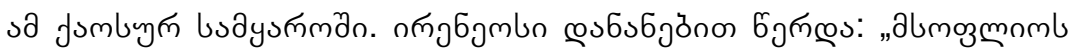

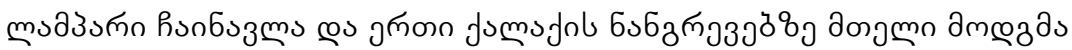

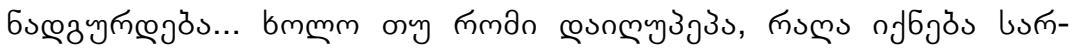

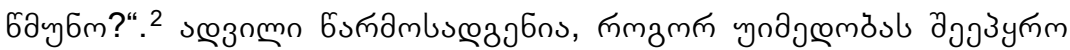

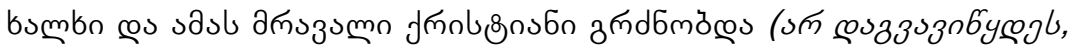

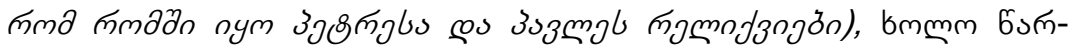

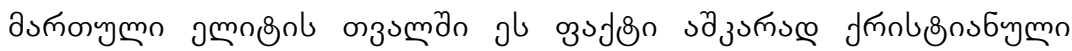

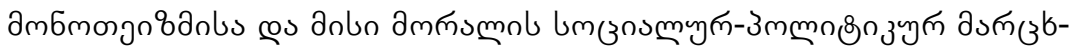

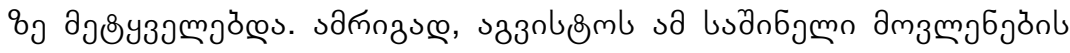

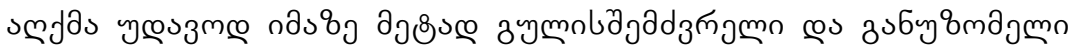

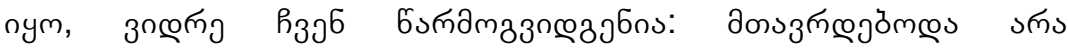

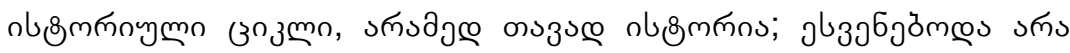
३пзимпя

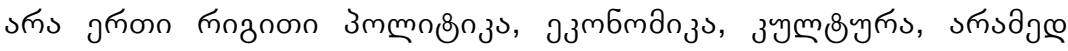

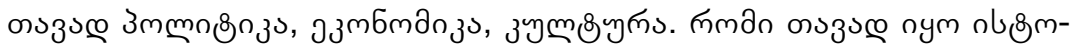

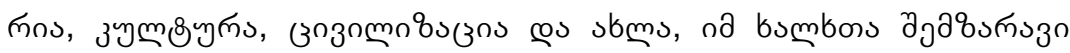

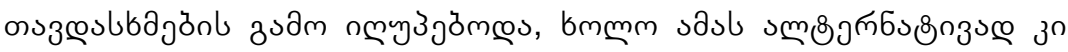

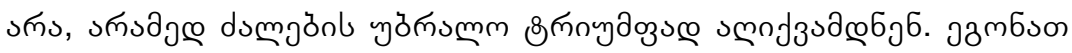

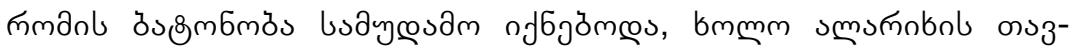

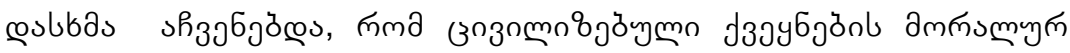

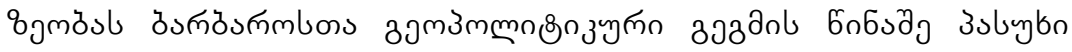

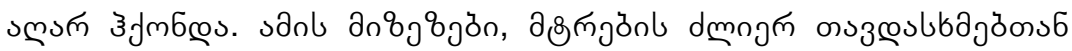

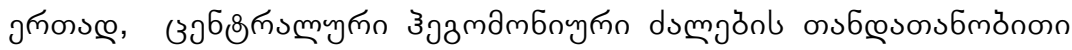

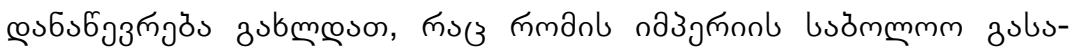

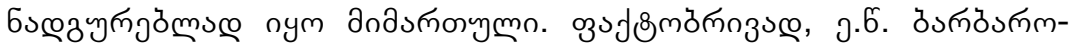

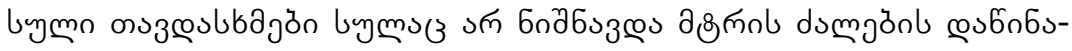

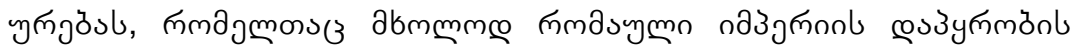

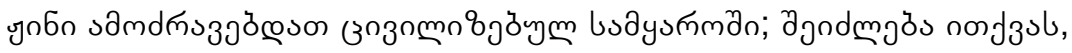

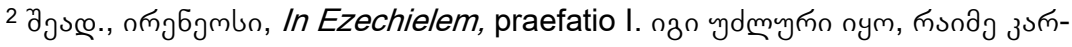

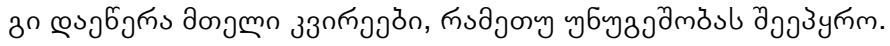




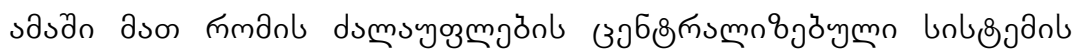

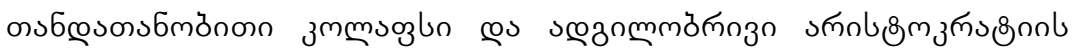

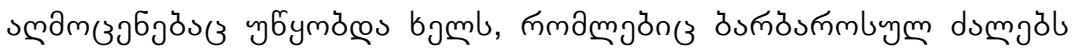

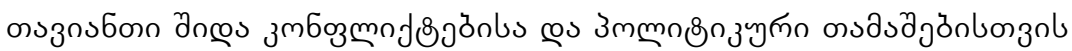

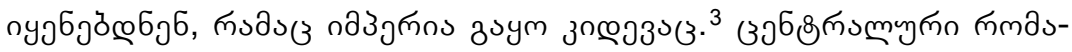

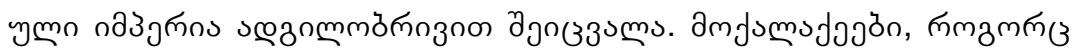

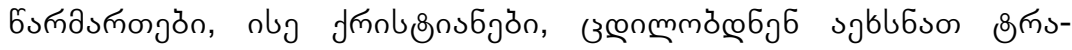

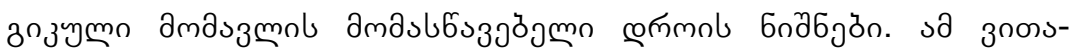

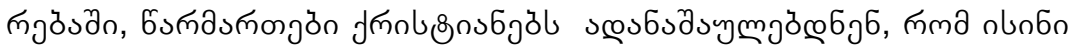

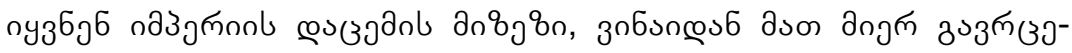

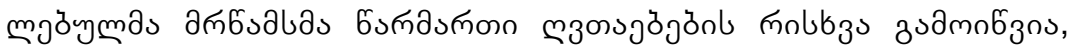

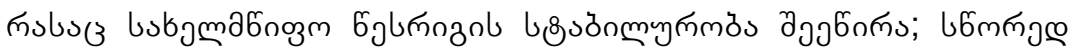

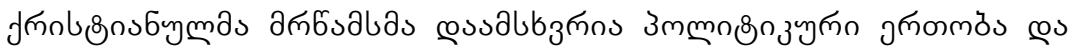

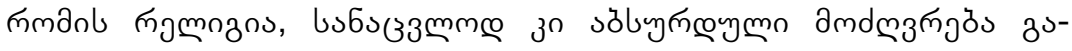

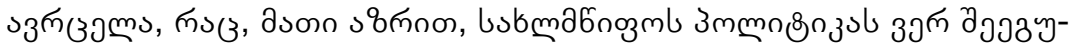

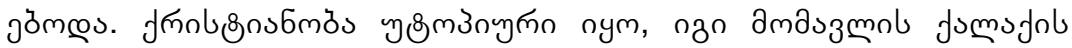

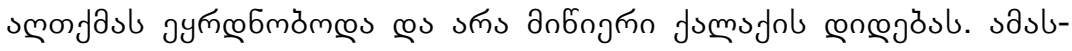

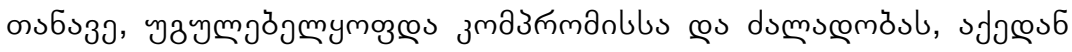

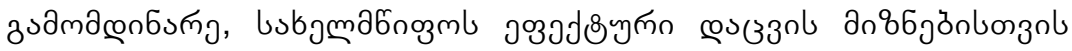

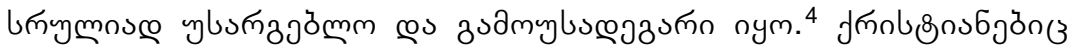

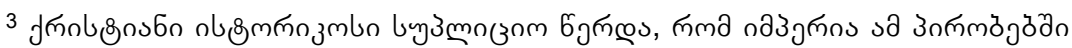

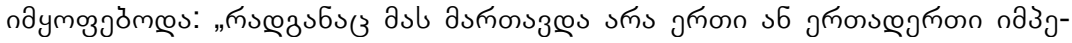

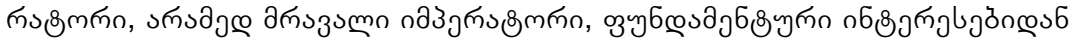

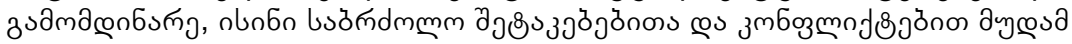
з১ymoznm

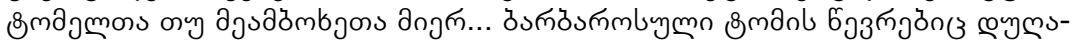

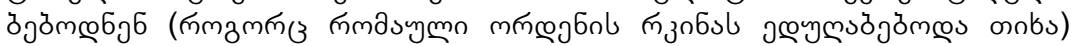

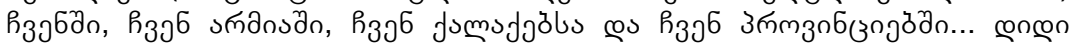

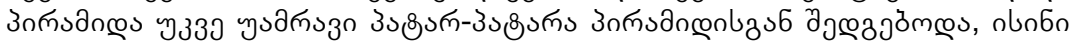

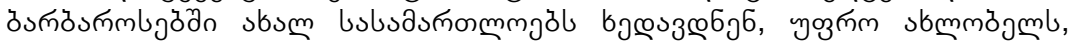

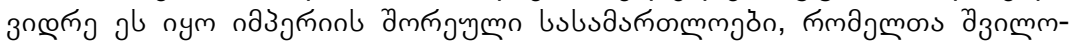

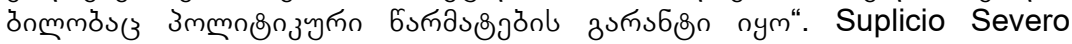
Chronica II, 3, 2: in Chroniques, a cura di Ghislaine de Senneville-Grave, SC 441, 1999, 228.

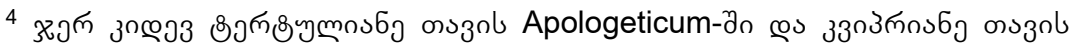

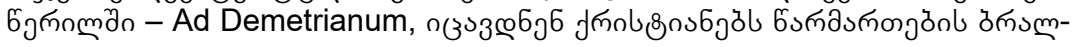

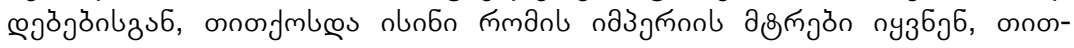




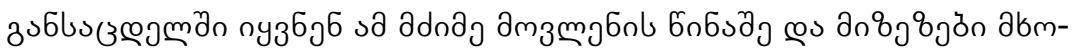

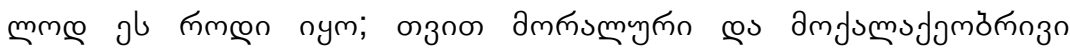

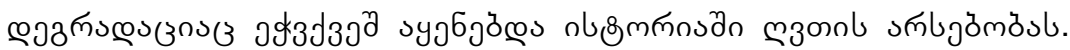

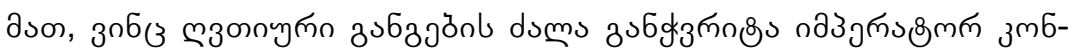

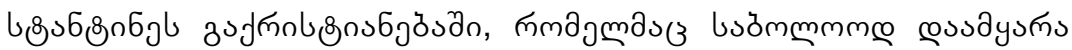

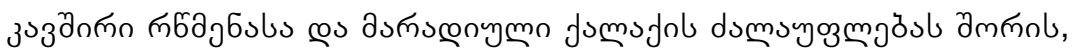

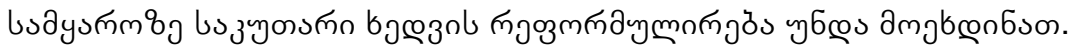

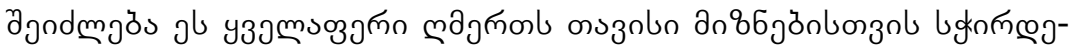

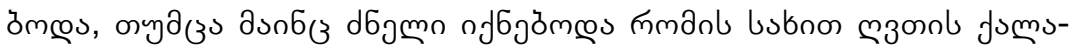

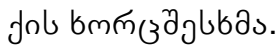

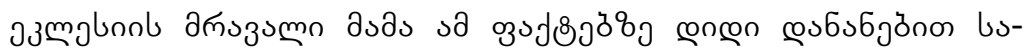

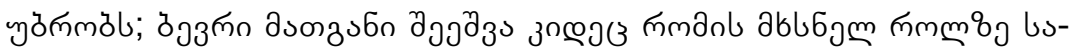

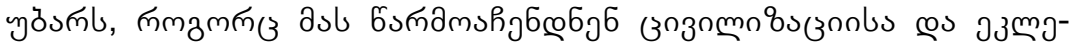

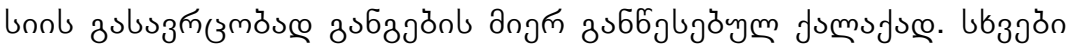

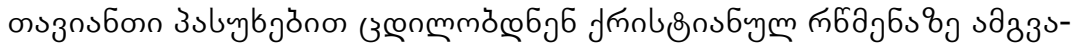

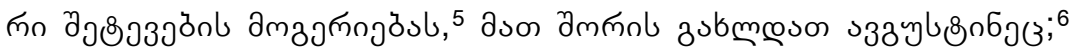

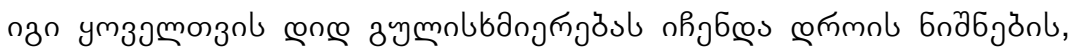

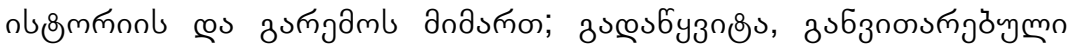

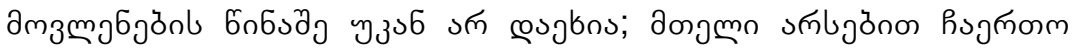

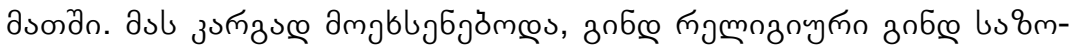

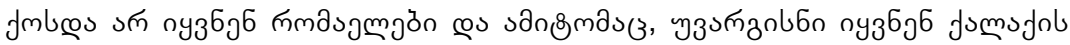

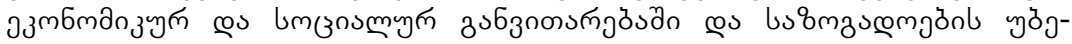

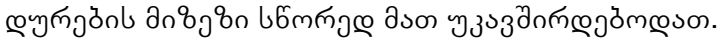

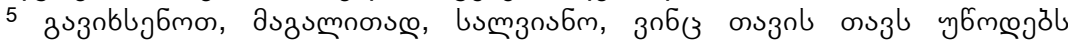

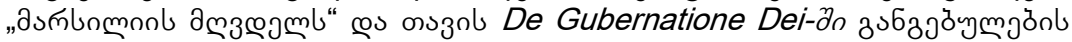

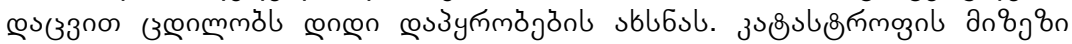

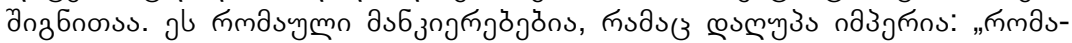

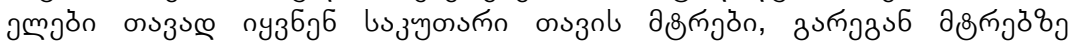

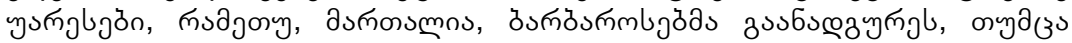

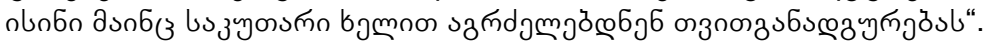

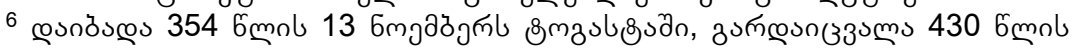

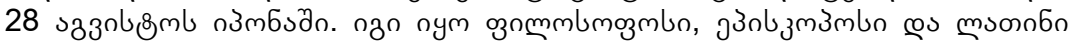

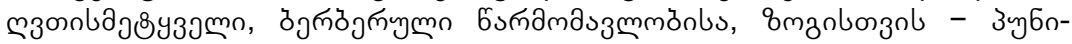
зупп.

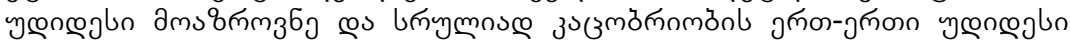

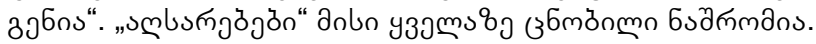




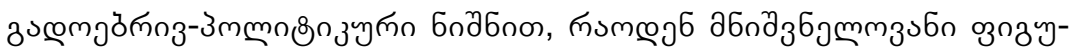

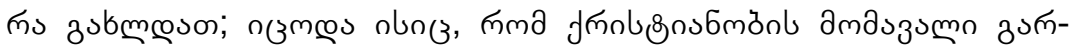

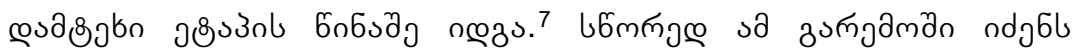
oुmmasu dnln 6sдmman De civitate Dei contra paganos (22 6nz-

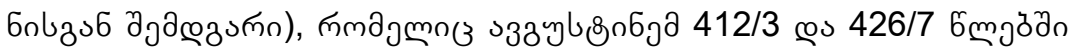

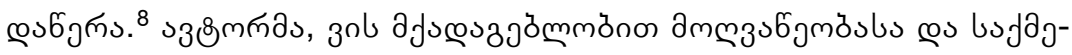

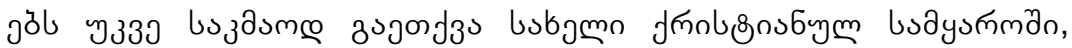

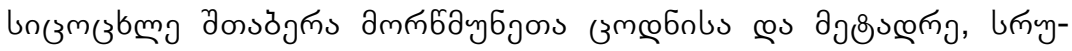

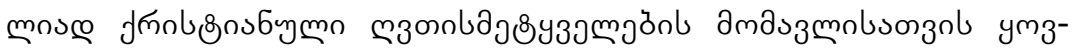

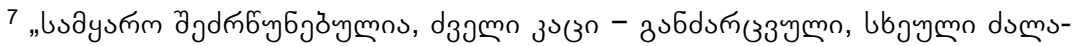

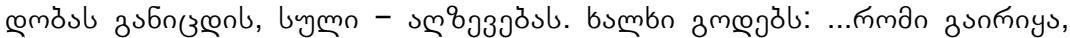

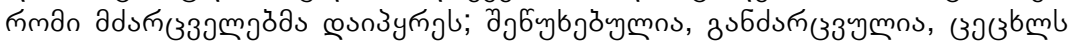

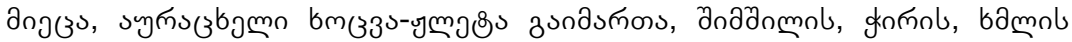
зدวm" (Sermo 296.6).

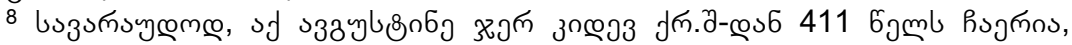

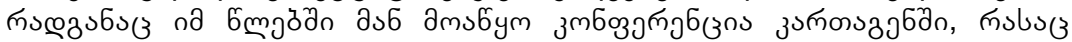

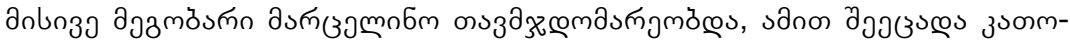

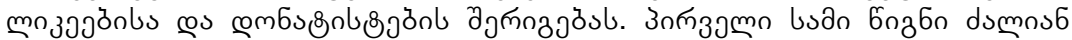

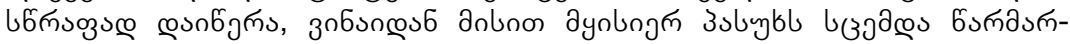

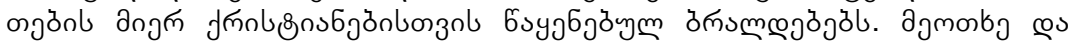

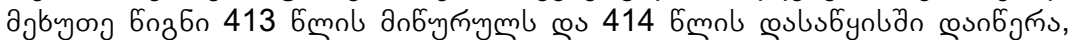

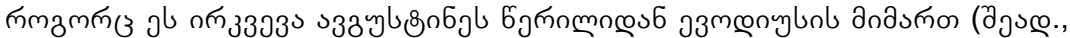

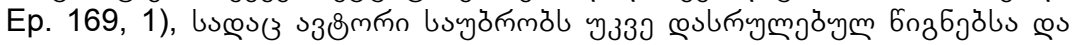

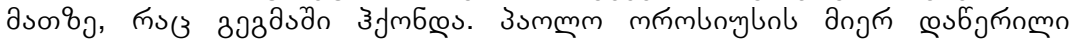

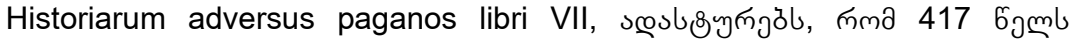

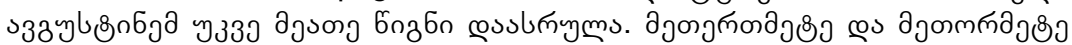

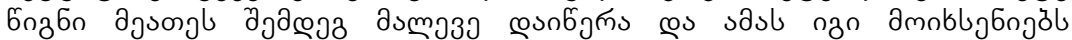

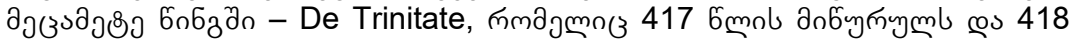

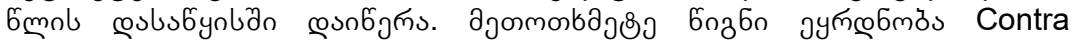

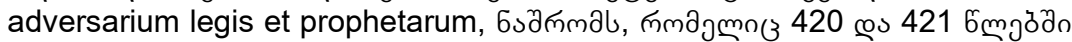

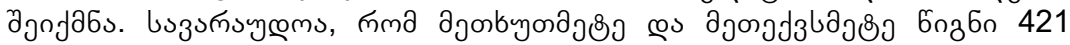

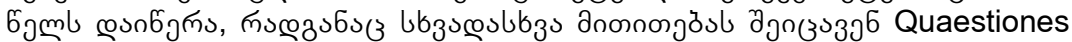

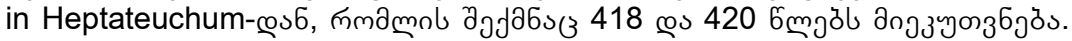

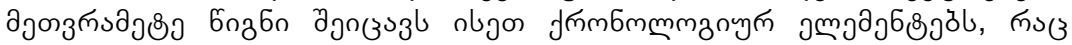

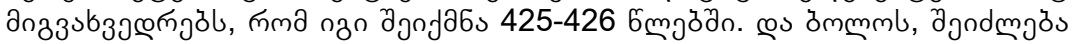

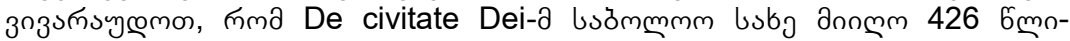

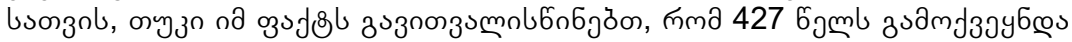

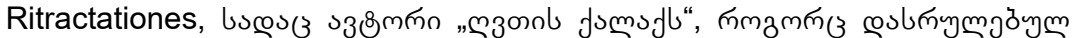
бздmmal, , Città Nuova, Roma 2010, XXXI-XXXIII. 


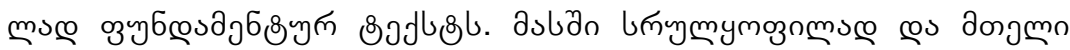

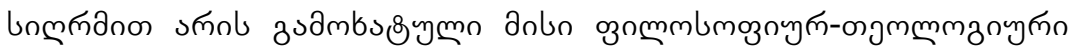

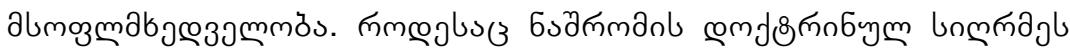

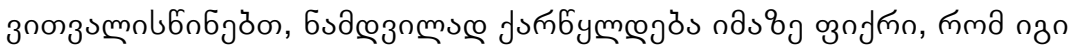

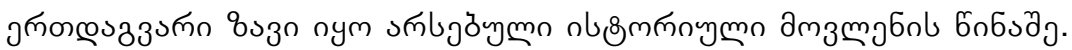
לا

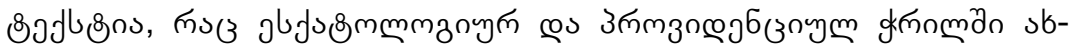

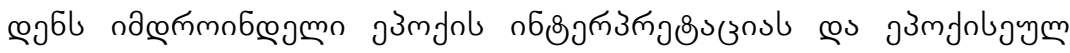

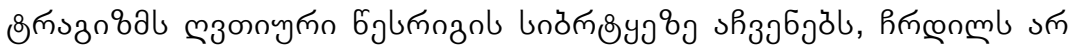

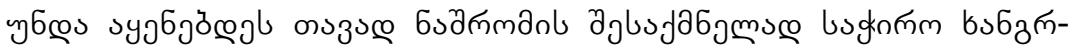
dmnз Зృ

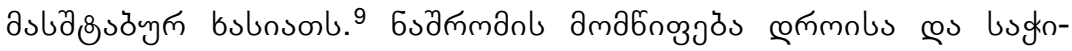

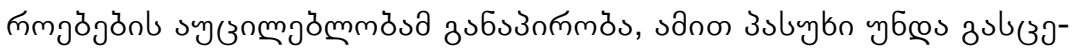

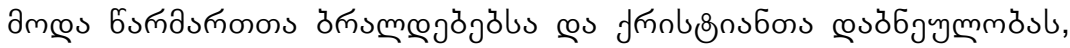

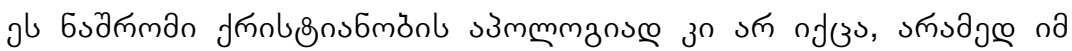

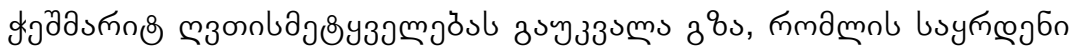

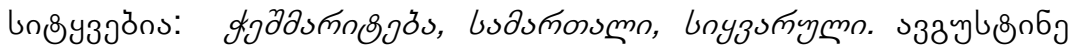

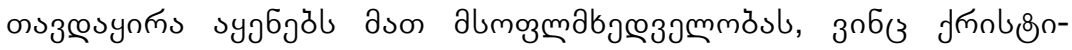

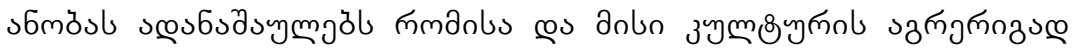

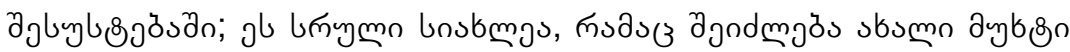

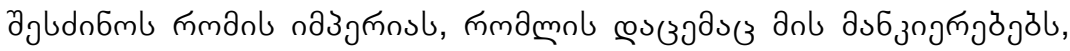

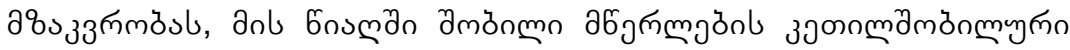

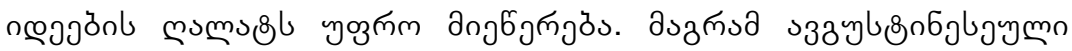

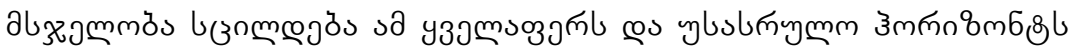

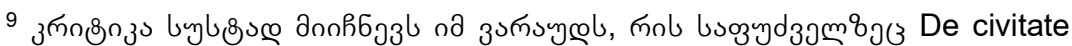

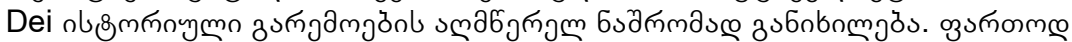

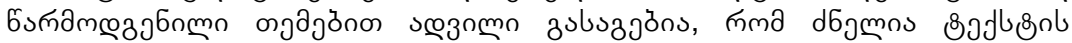

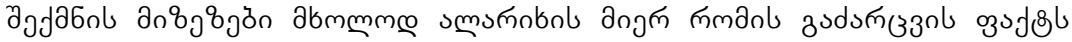

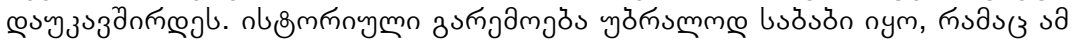

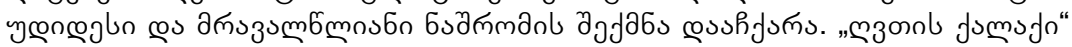

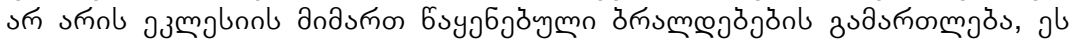

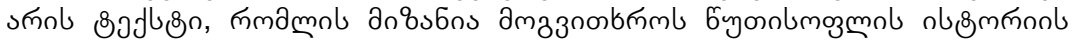

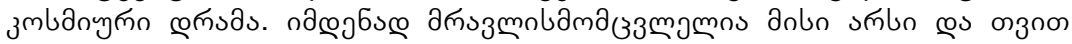

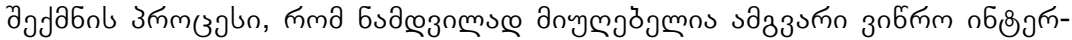

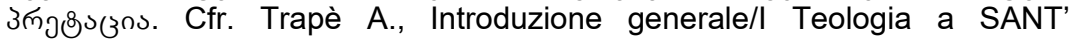
AGOSTINO, La città di Dio, NBA V/1, Roma, 1978, 1990, XIII. 


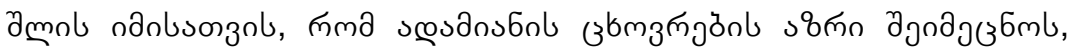
поз, дn

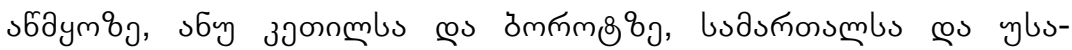

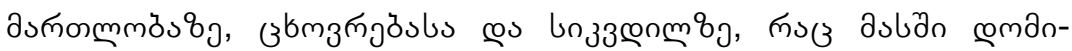

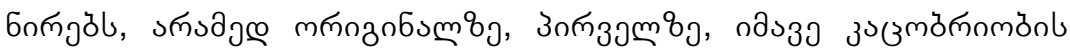

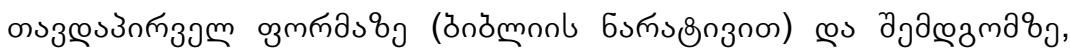

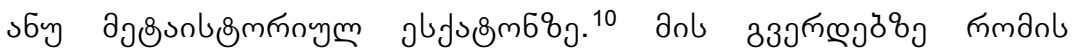

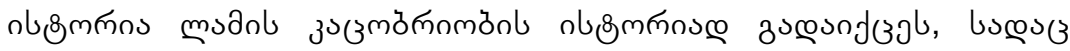

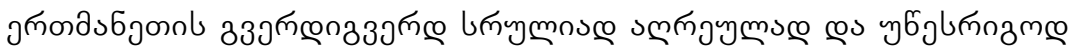

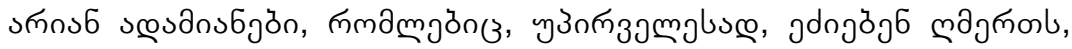

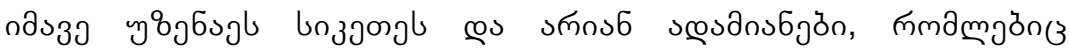

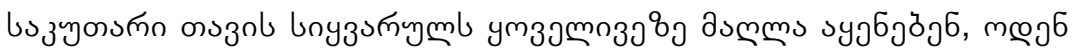

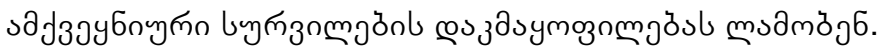

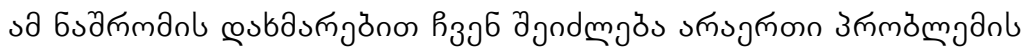

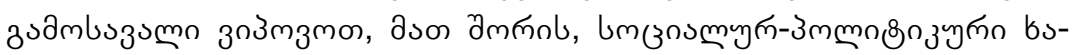

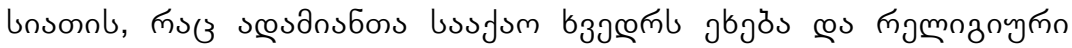

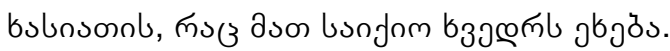

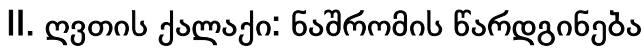

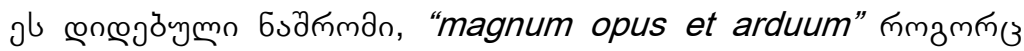

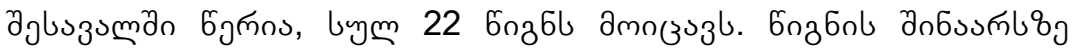

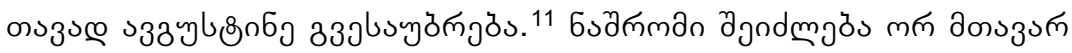

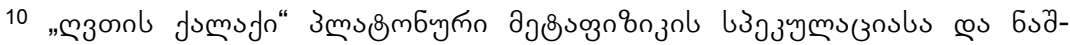

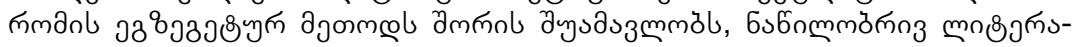

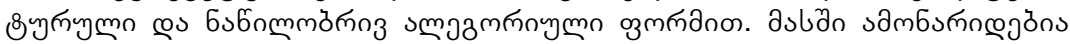

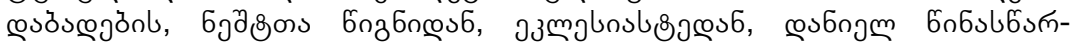

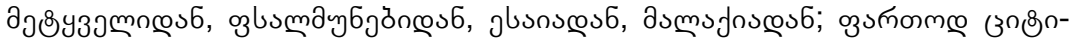

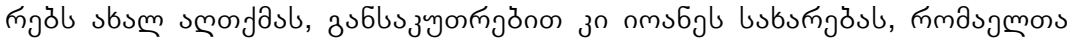

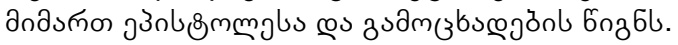

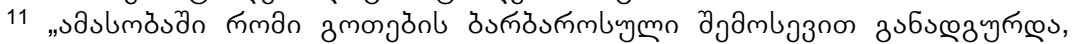

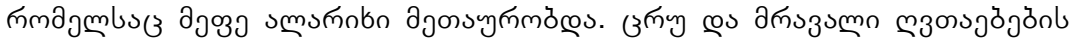

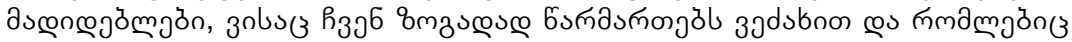

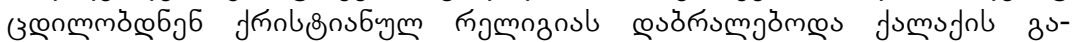

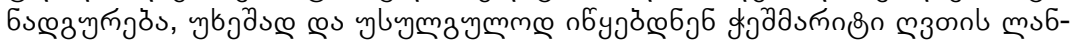

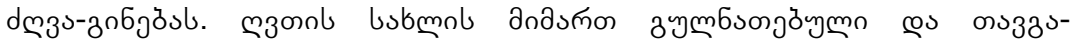




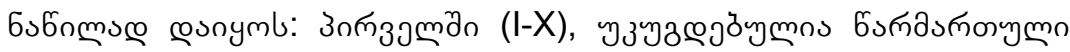

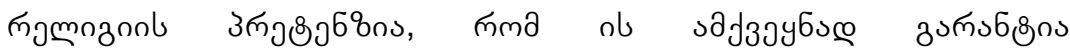

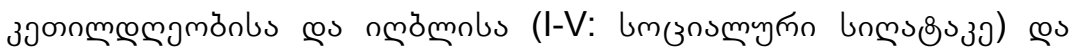

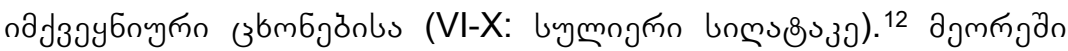

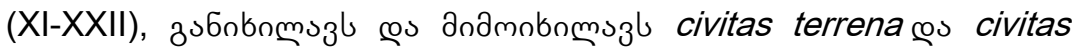

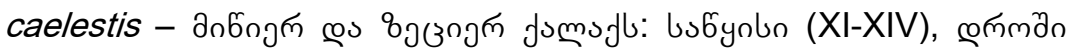
zuбznos

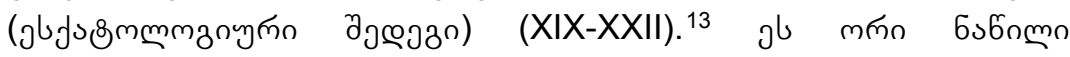

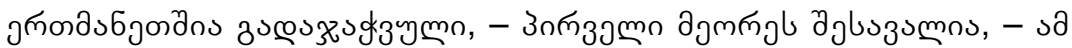

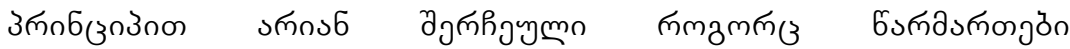

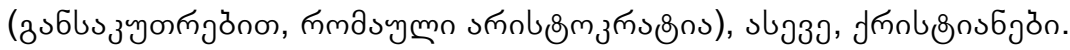
mmo jumsjol (civitas Deie civitas hominis) jnonasбjonbuzu6

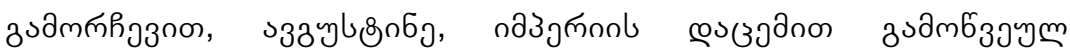

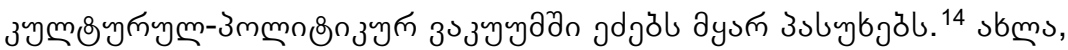

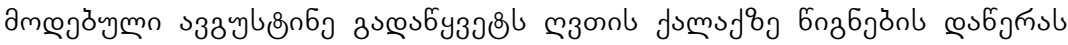

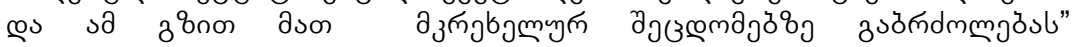
(Retractationes 43.1).

12 zubluзу

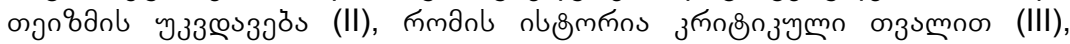

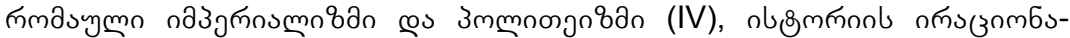

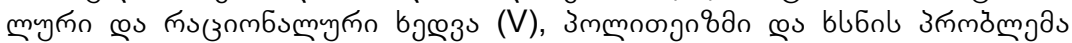

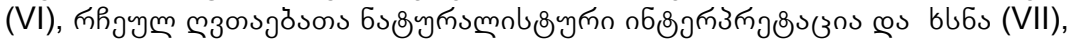

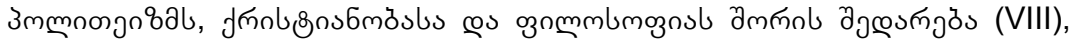

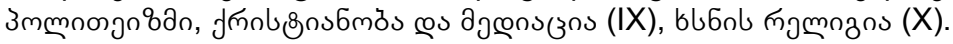

13 ajogตna

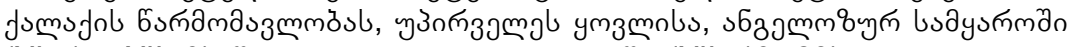

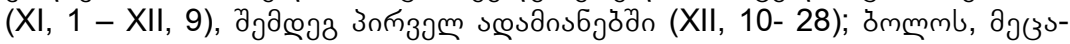

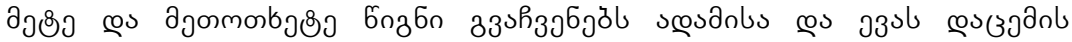

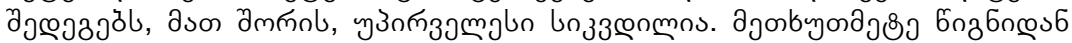

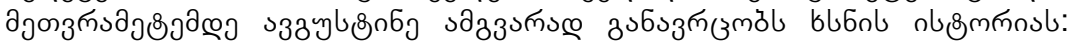

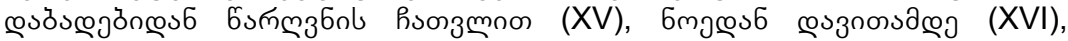

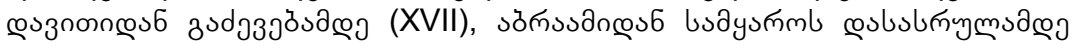

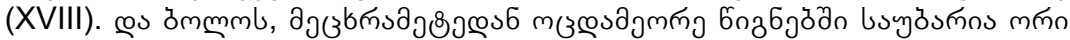

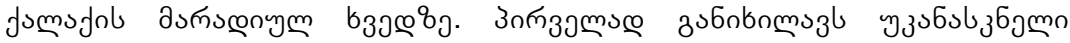

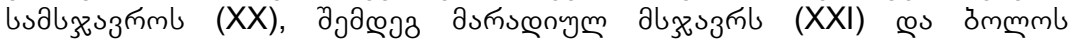

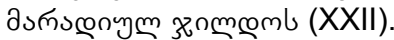

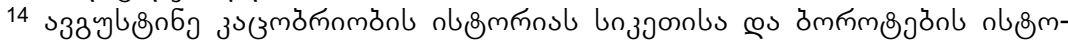

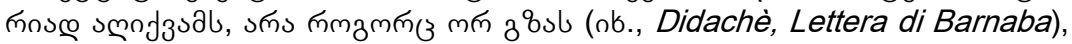




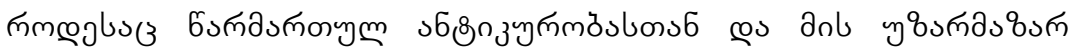

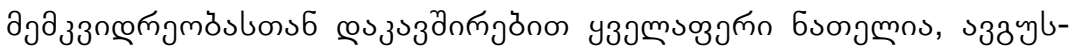

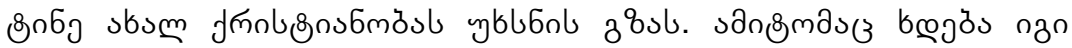

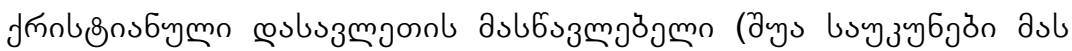

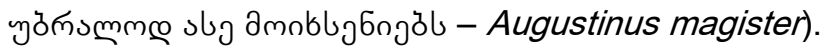

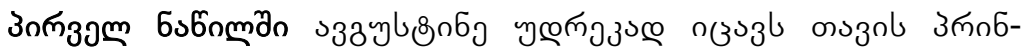

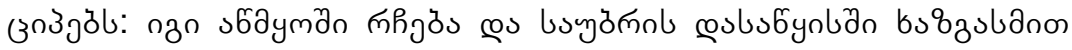

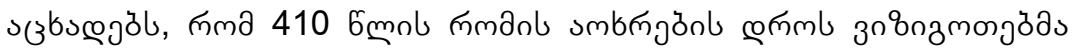

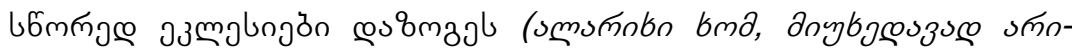

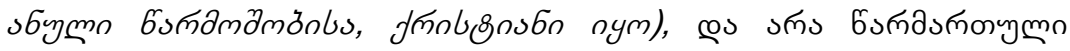

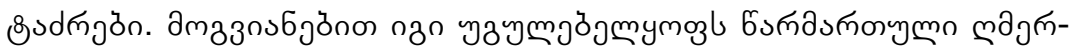

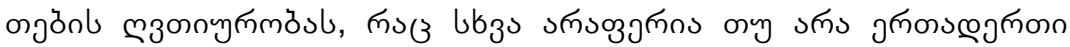

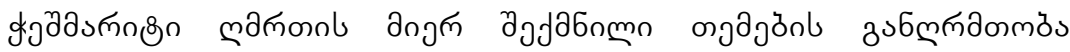

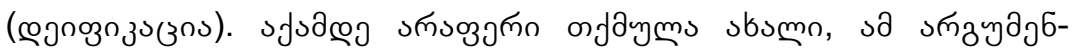

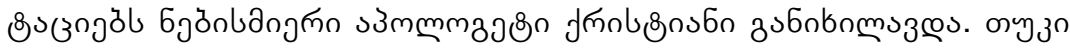

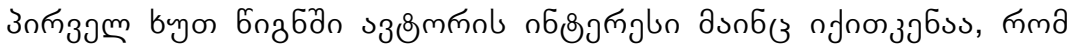

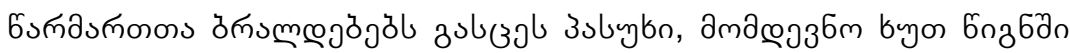

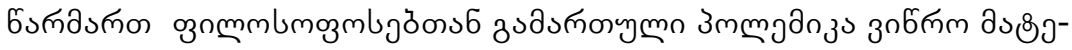

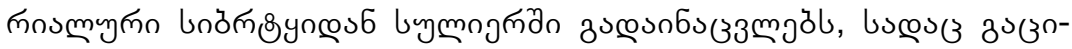

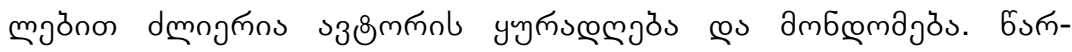

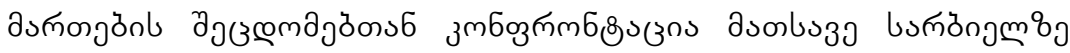

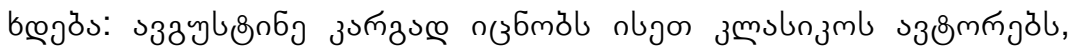

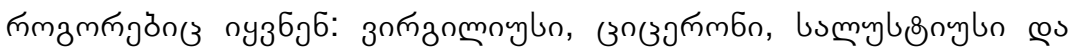

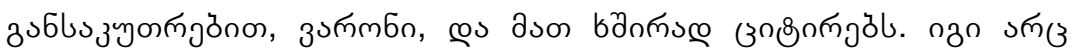

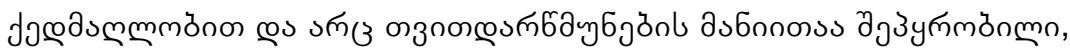

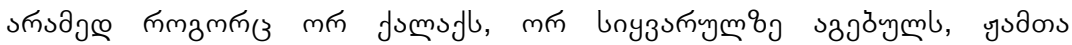

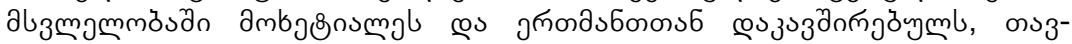

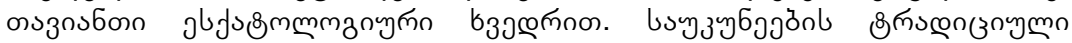

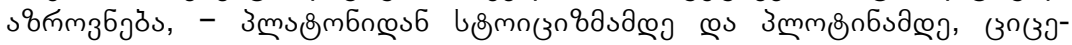

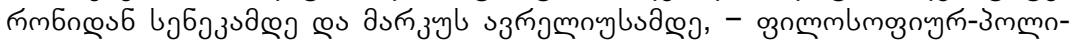

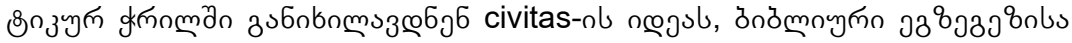

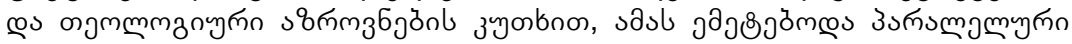

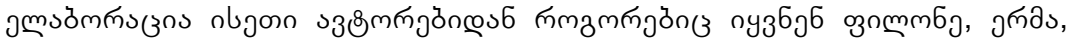

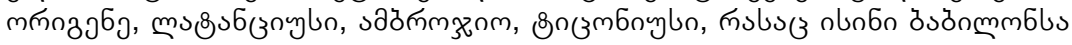

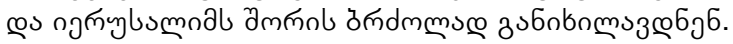




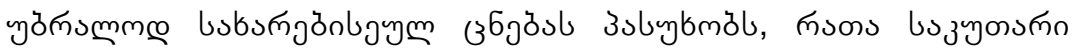

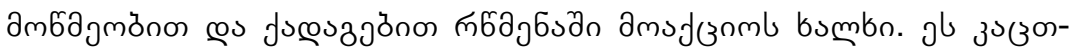

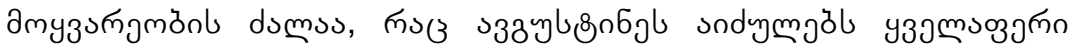

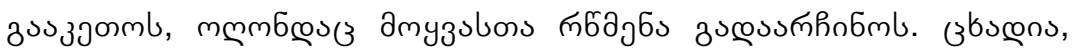

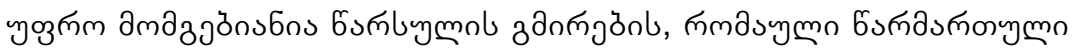

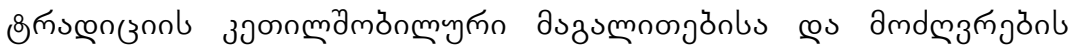

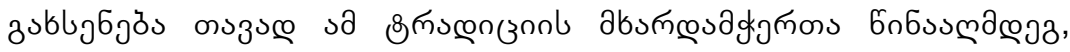

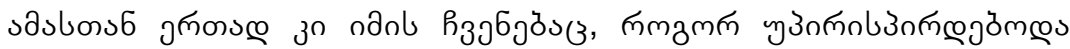

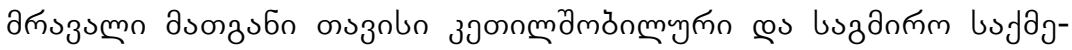

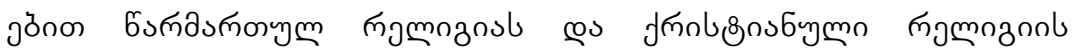

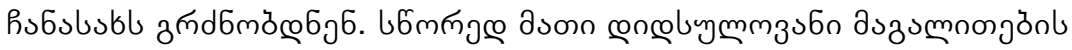

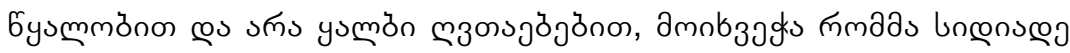

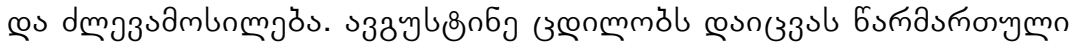

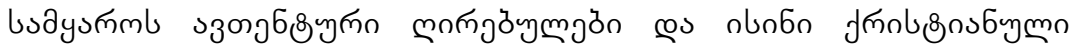

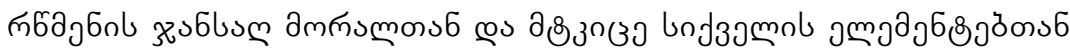

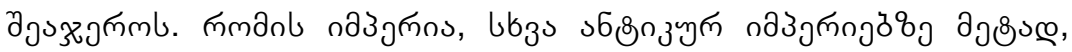

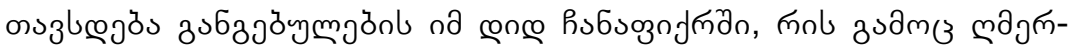

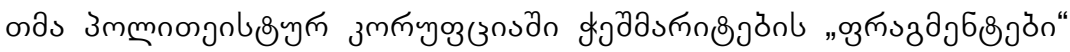
hımonm @s

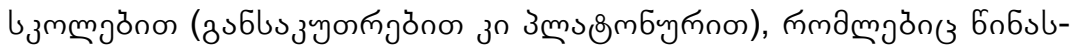

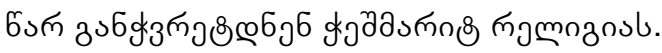

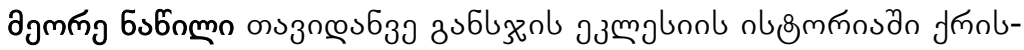

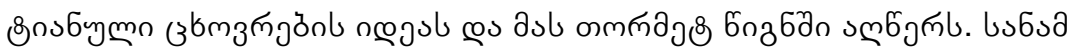

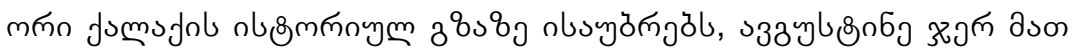

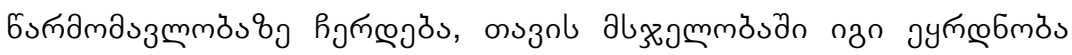

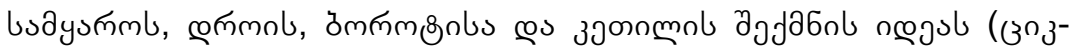

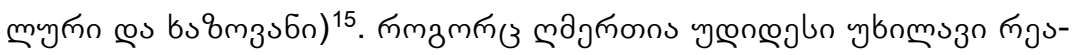

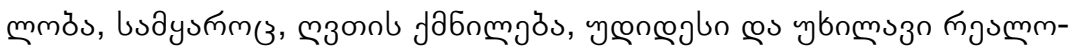

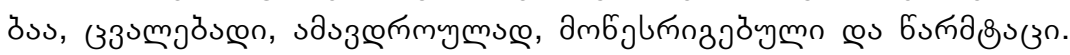

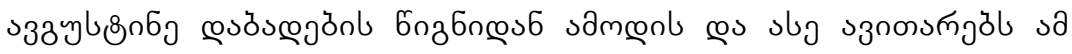

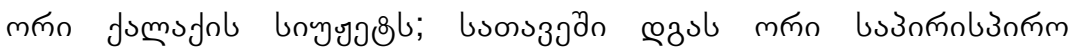

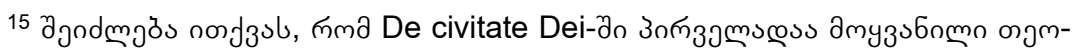

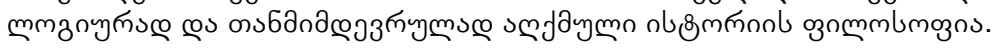




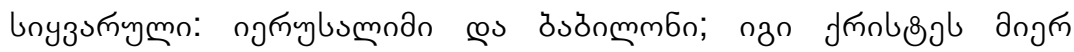

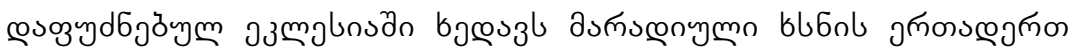

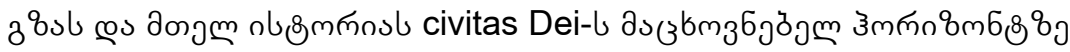

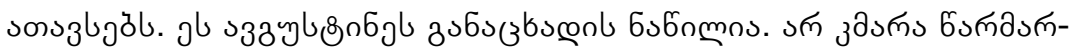

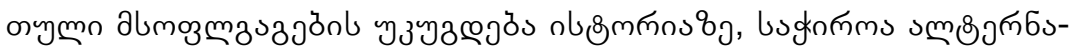

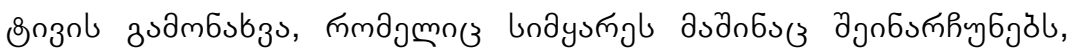

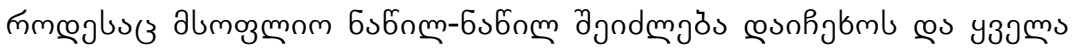

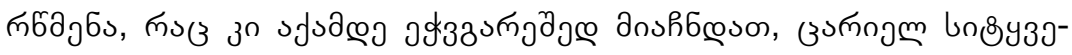

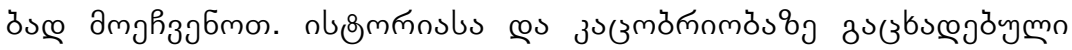

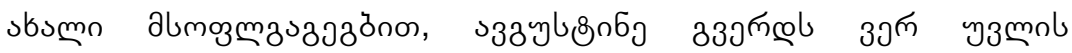

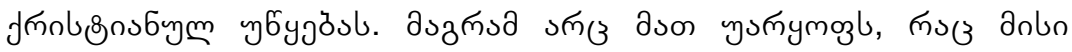

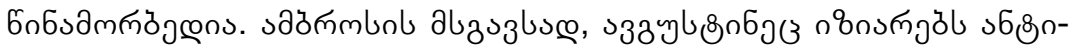

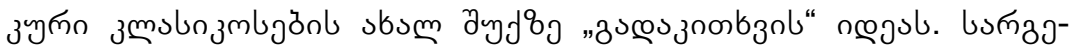

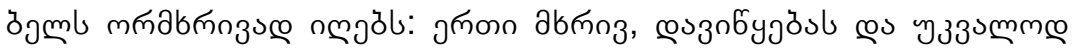

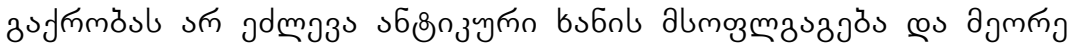

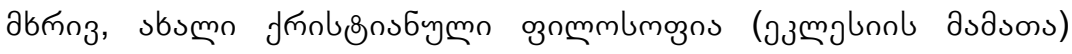

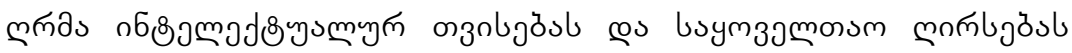
ndjढl.

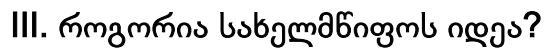

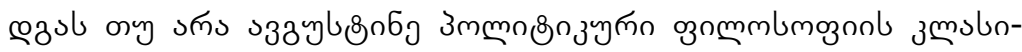

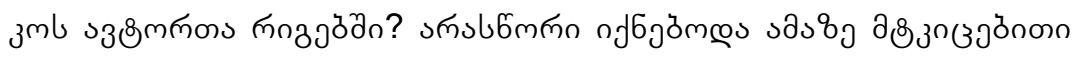

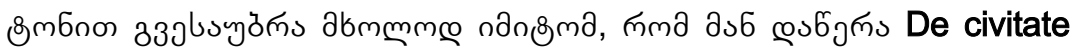

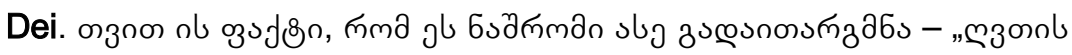

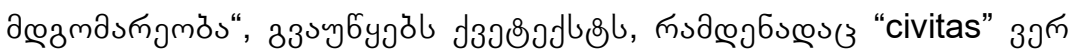

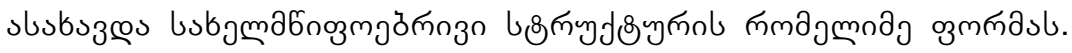

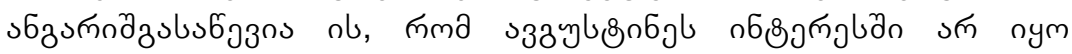

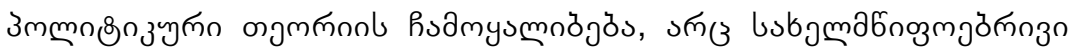

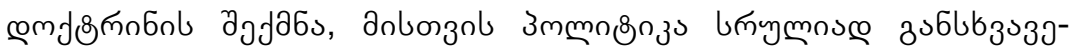

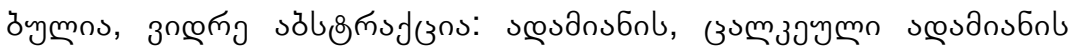

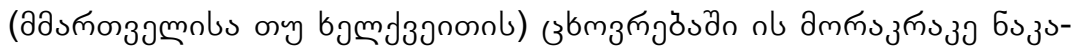

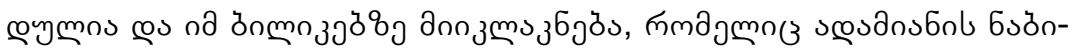

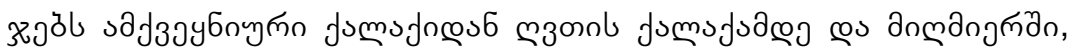




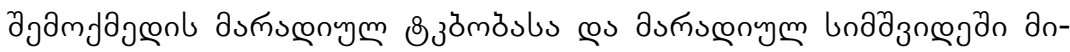

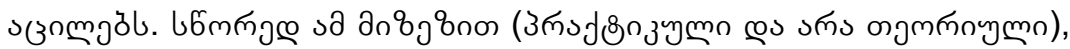

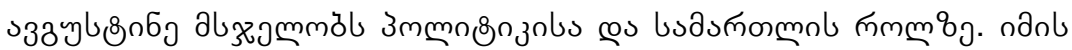

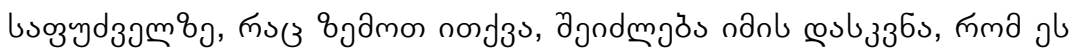

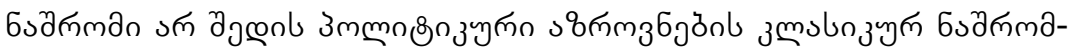

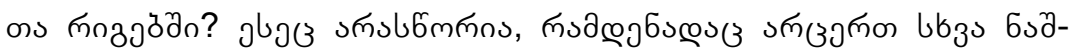

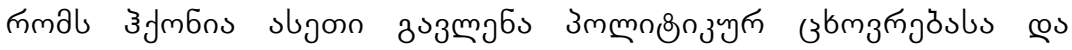

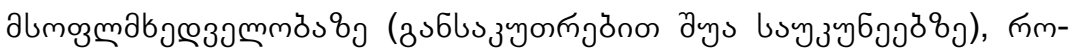

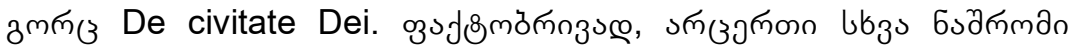

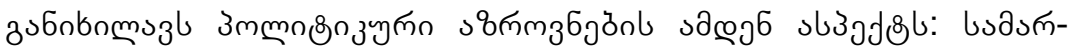

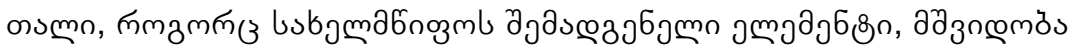

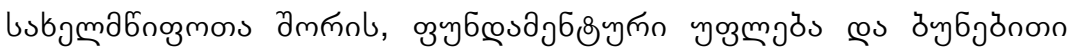

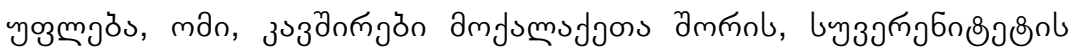

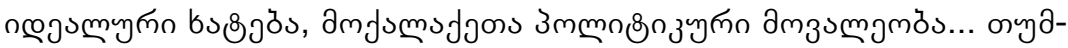

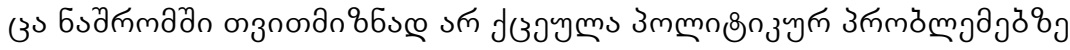

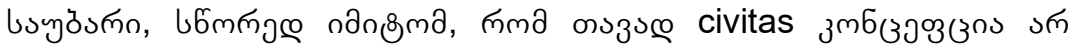

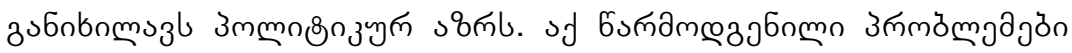

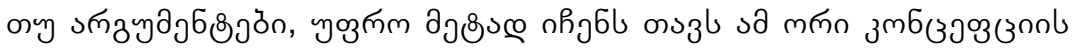

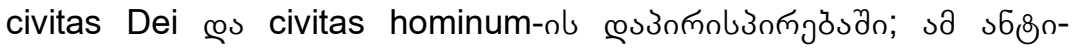

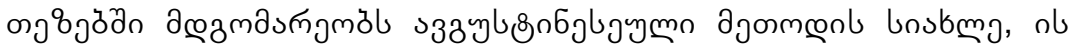

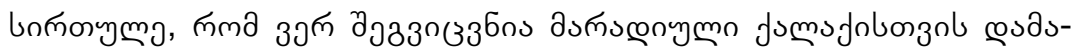

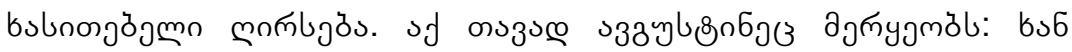

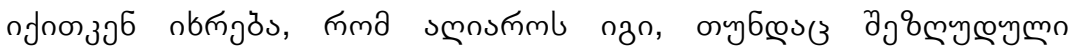

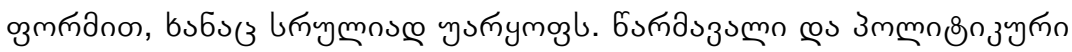

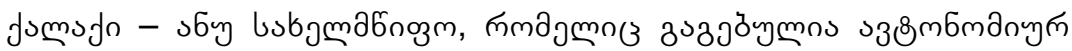

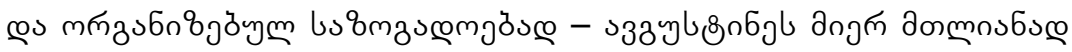

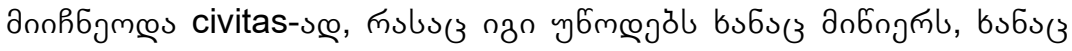

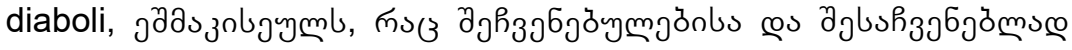

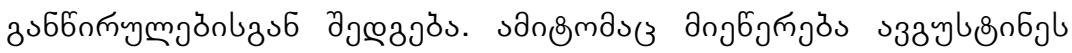

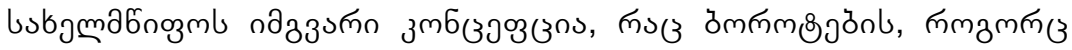

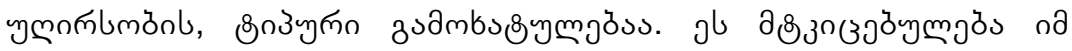

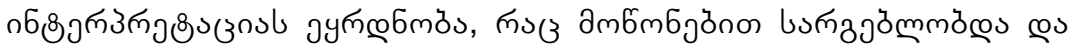

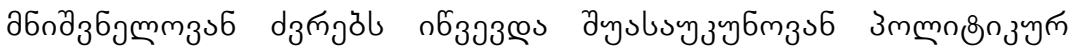

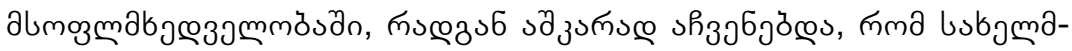




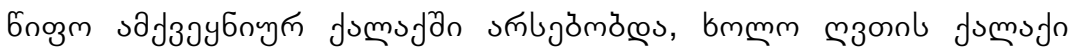

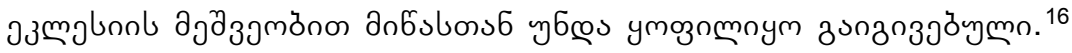

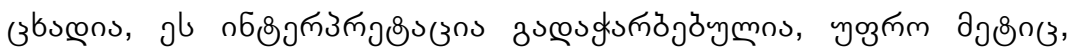
Әъœumns:

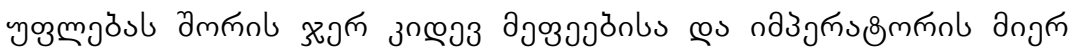

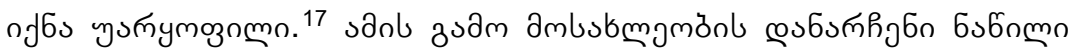

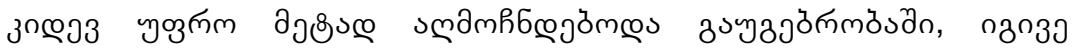

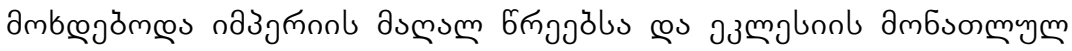

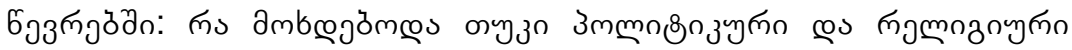

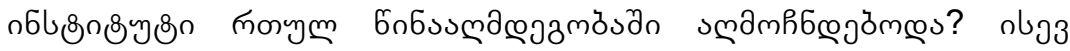

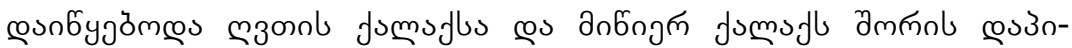

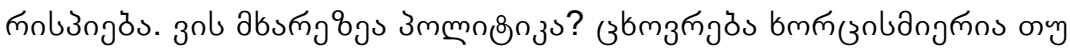
bymolangmo?

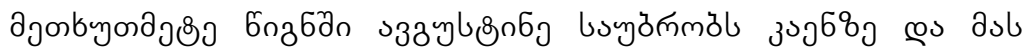

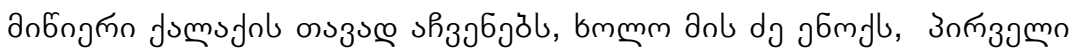

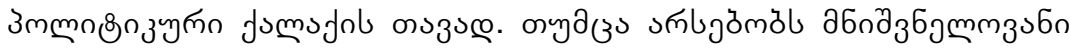

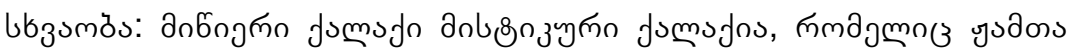

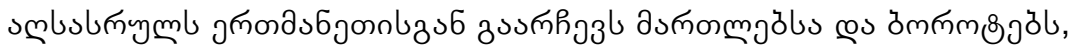

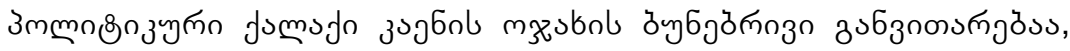

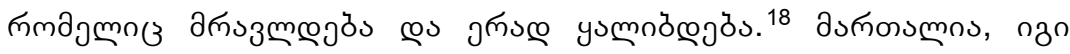

16 yguœ., Cotta S., Edizioni di Comunità, 1960,15.

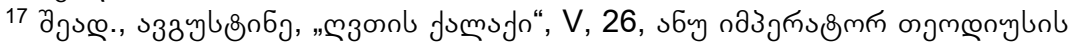

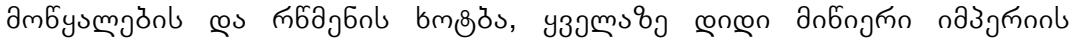

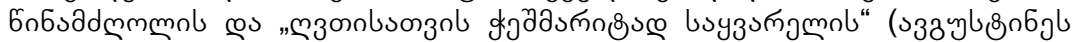

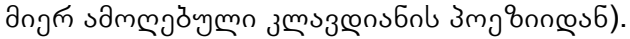

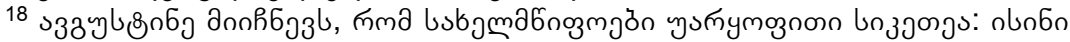

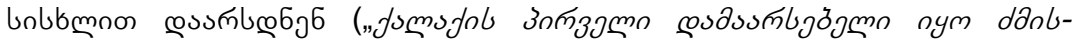

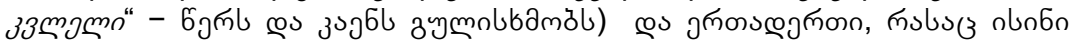

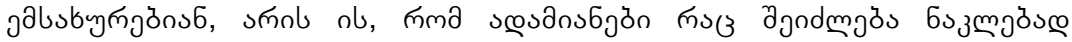

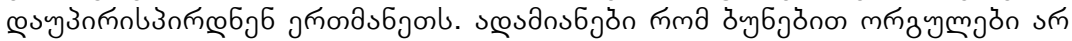

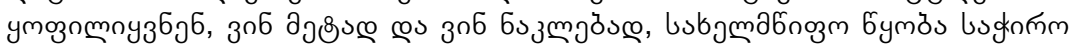

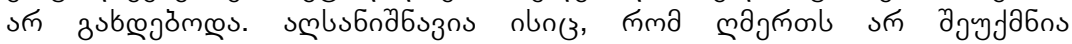

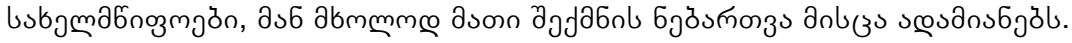

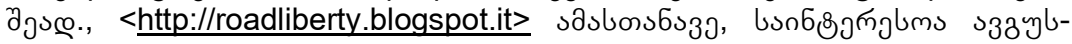

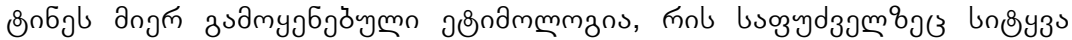

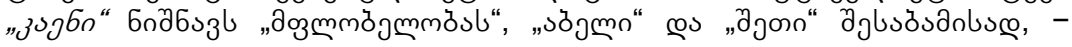

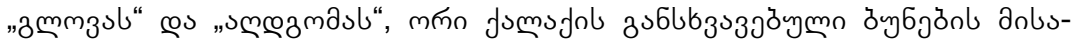




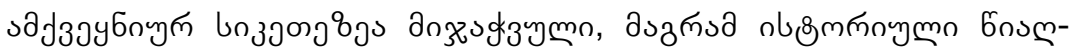

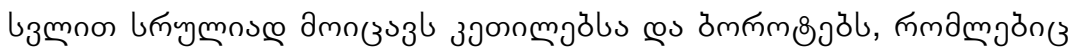

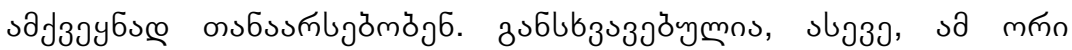

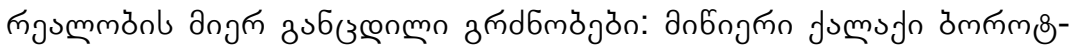

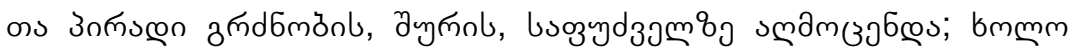

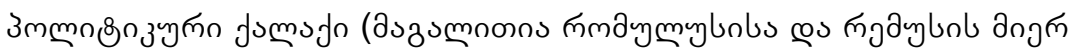

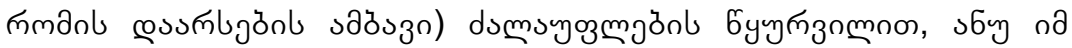

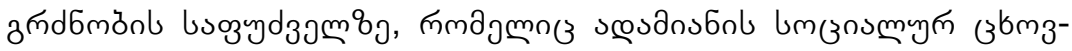

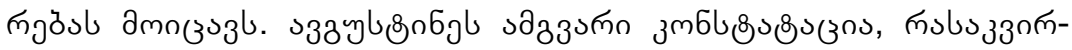

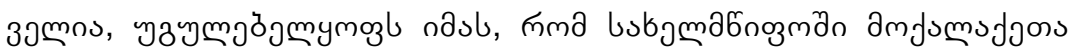

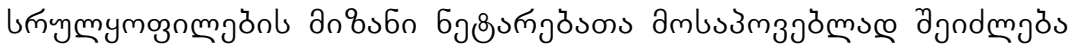

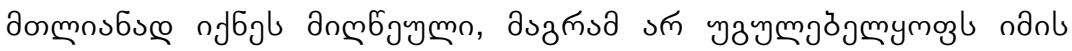

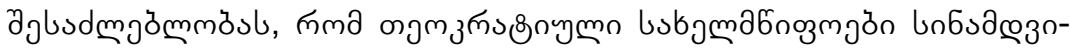

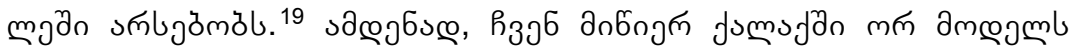

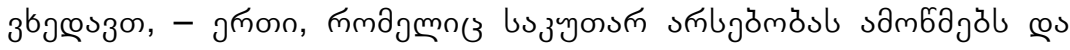

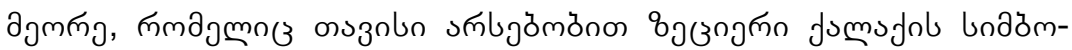

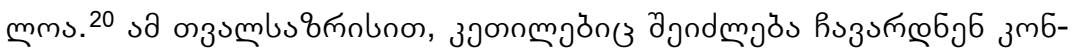

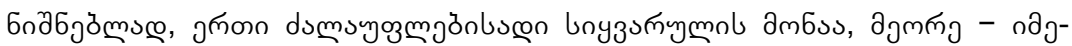

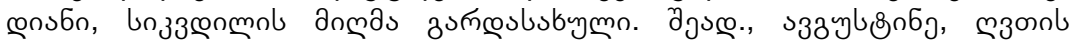
jumsjo, XV,17 s.

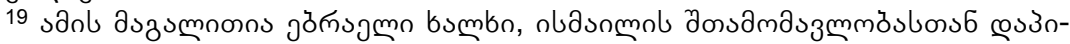

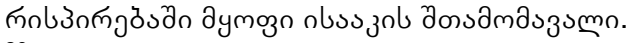

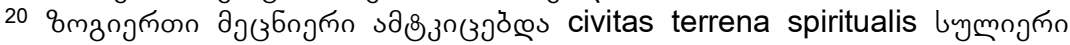

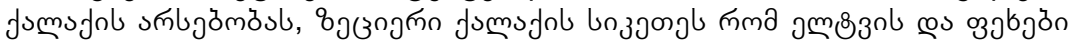

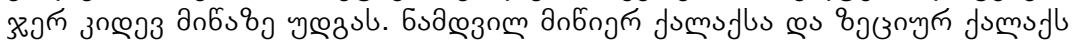

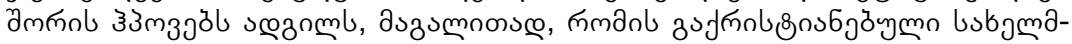

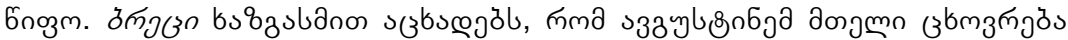
пmanl zufmols

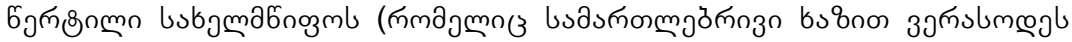

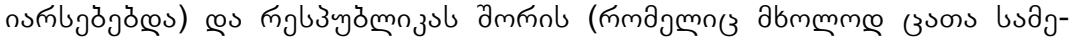

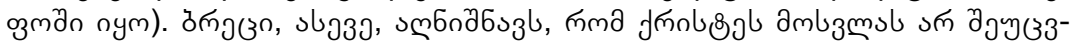

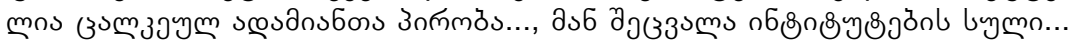

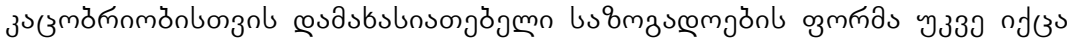

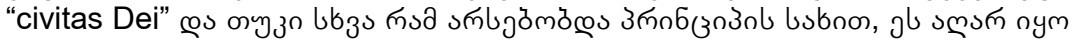

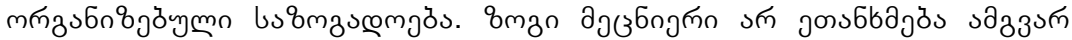

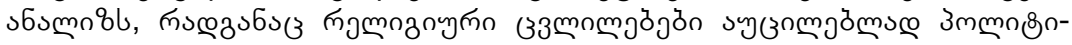

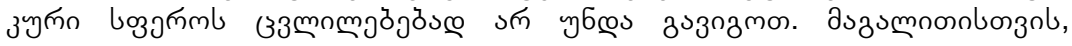




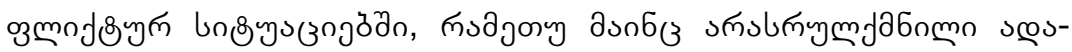

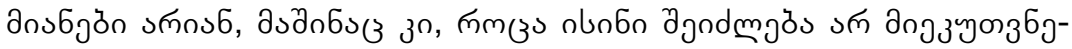

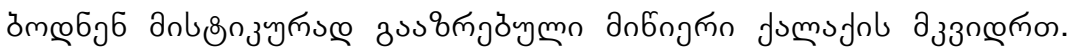

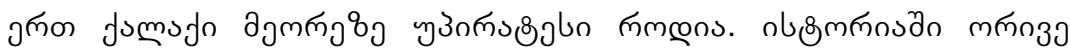

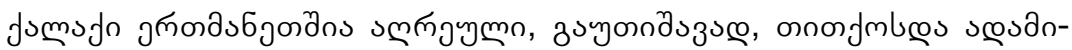

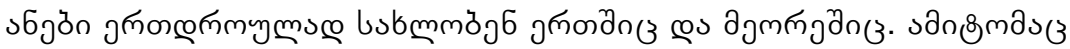

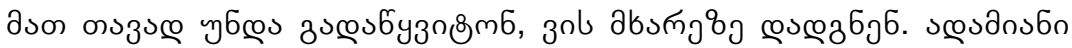

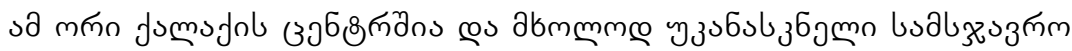

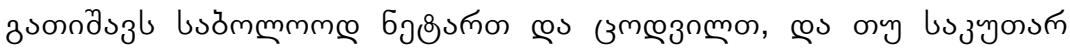

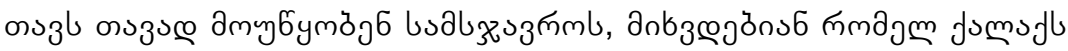

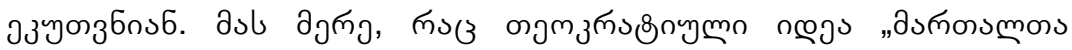

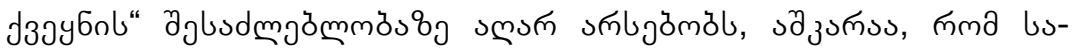

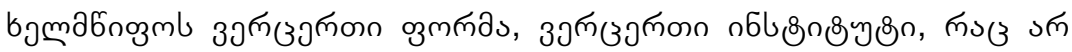

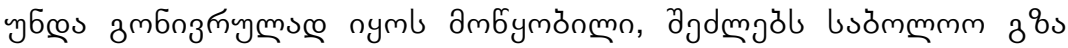

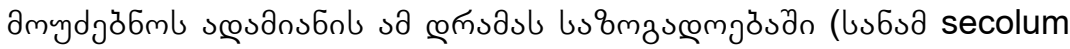

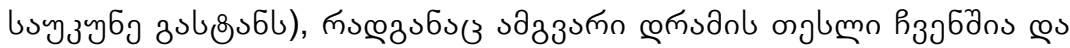

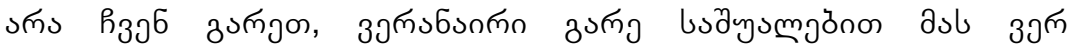

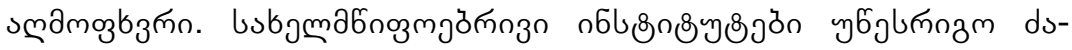

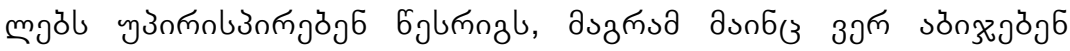

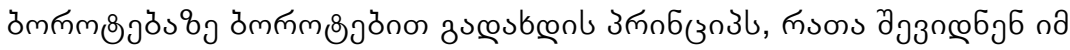

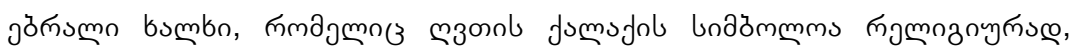

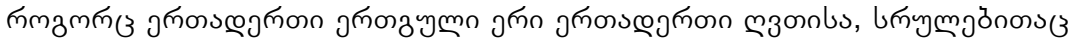

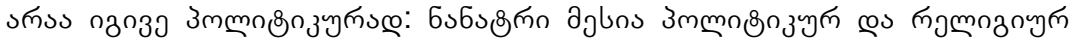

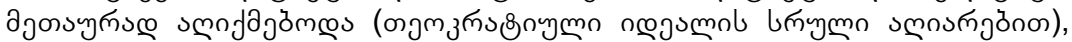

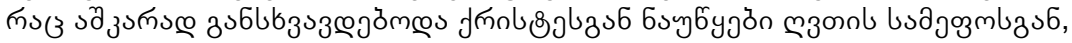

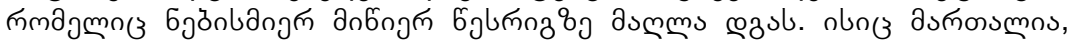

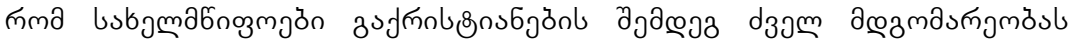

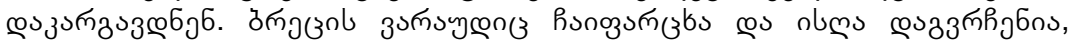
зsав

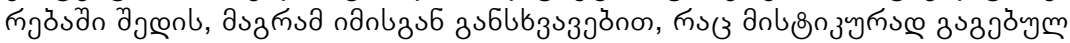

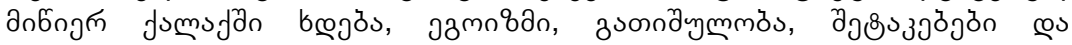

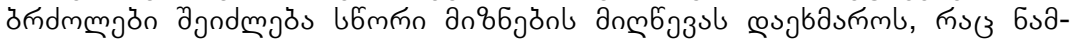

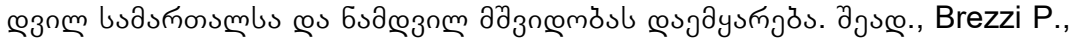
Una "Civitas terrena Spiritualis" come ideale storico-politico di Sant'Agostino, in: Augustinus Magister (Congres International Augustinien, Paris, 21-24 septembre 1954), Vol. II (Communications), Paris, Etudes Augustiniennes, 1954, 916. 


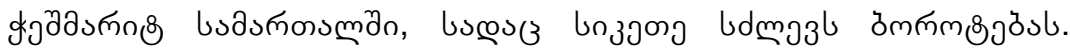

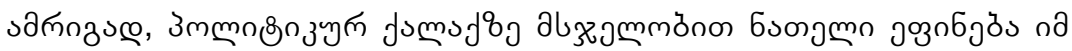

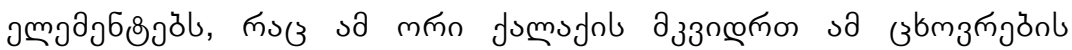
as6dnmig s

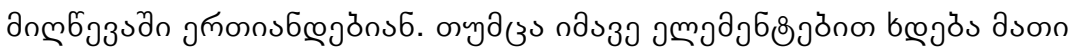
аззозпm зدамm

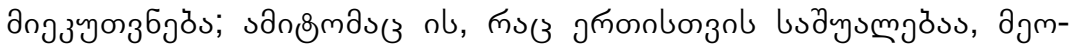
пु

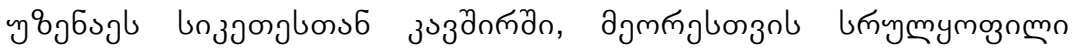

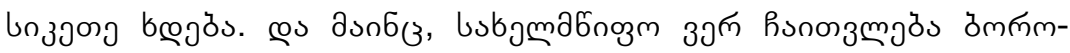

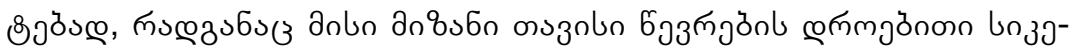
mol y

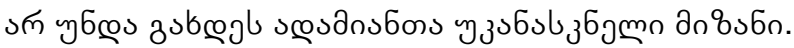

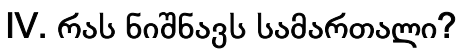

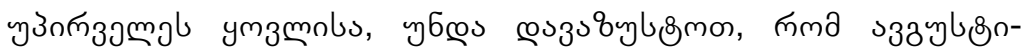

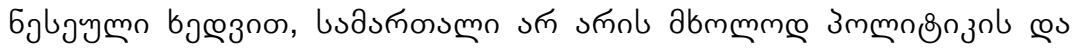

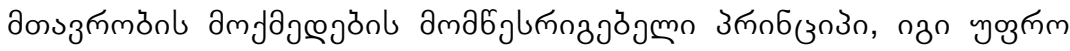

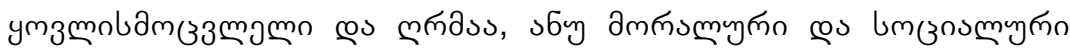

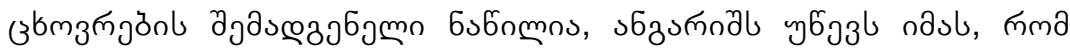

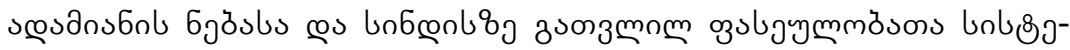

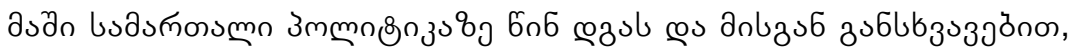

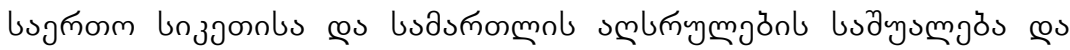

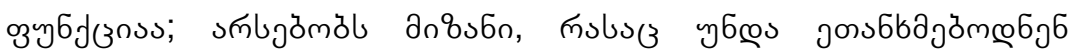

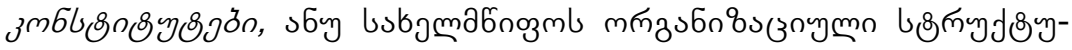

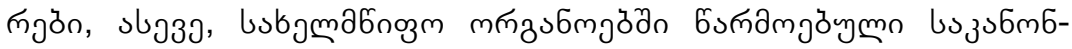

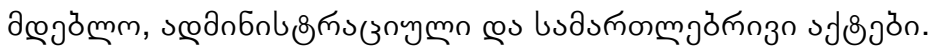

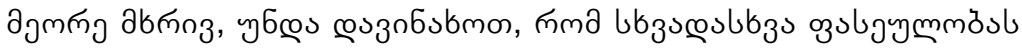

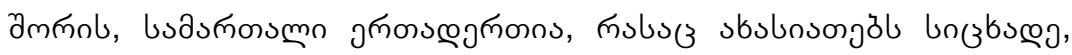

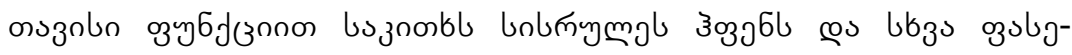

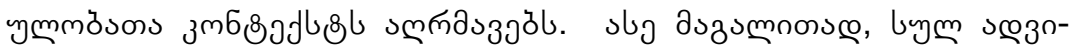

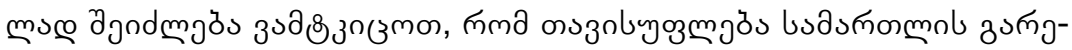

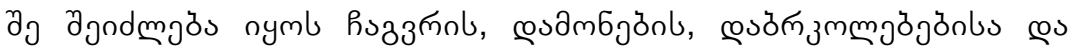




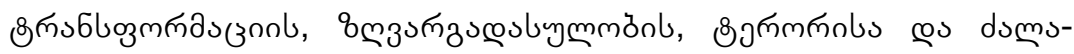

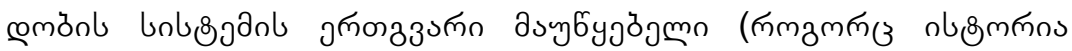

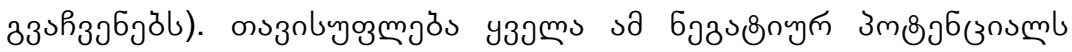

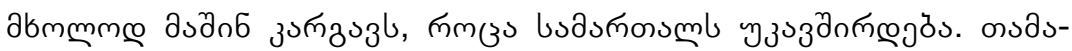

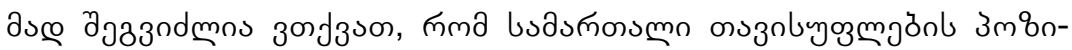

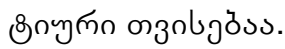

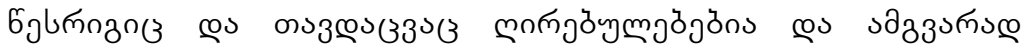

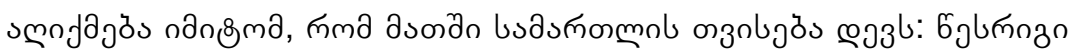

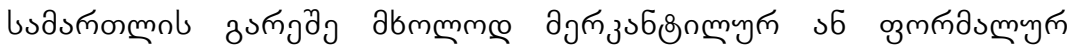

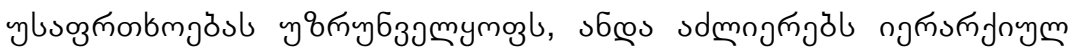

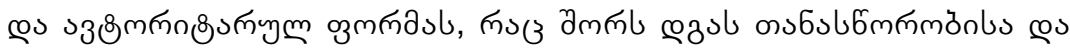

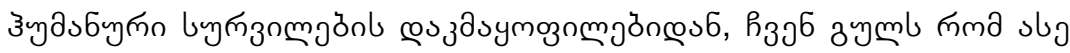

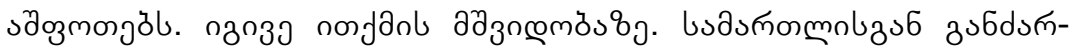

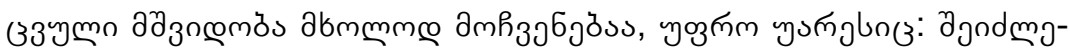

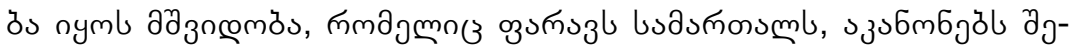

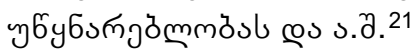

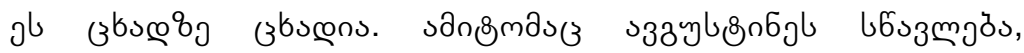

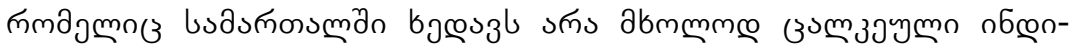

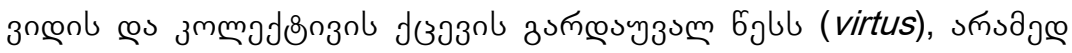

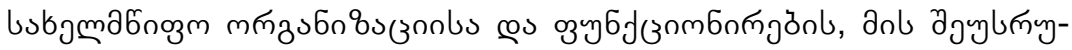

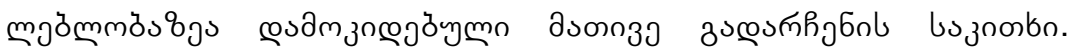

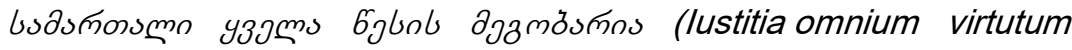
comes) sqyb \&

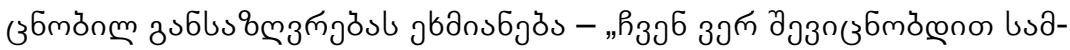

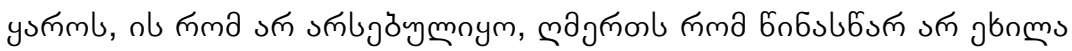

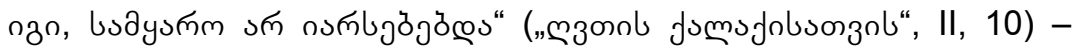

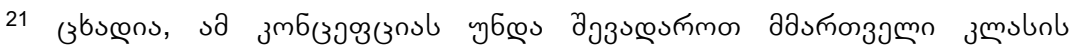

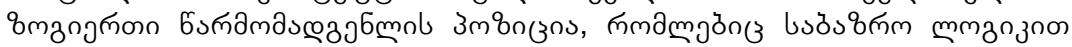

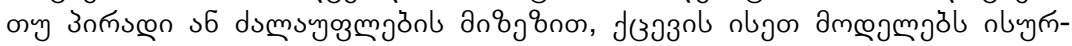

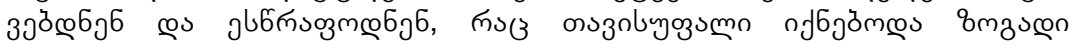

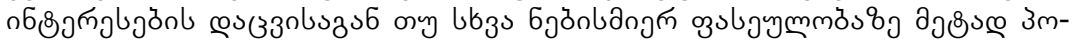

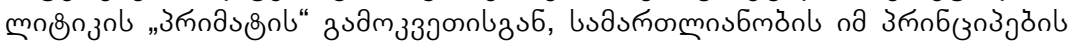

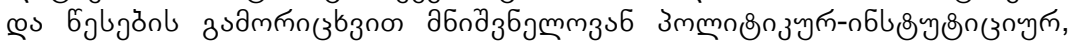

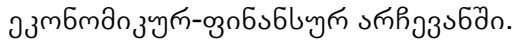




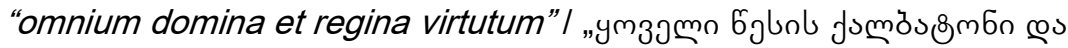

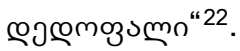

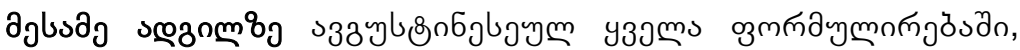

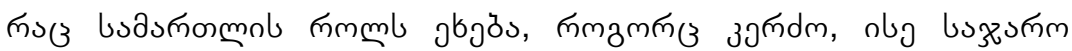

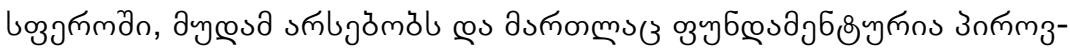

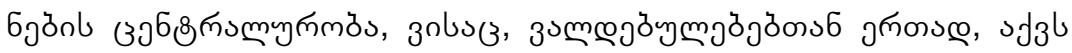

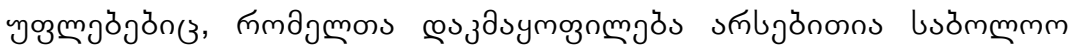

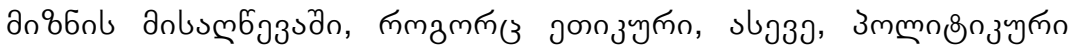

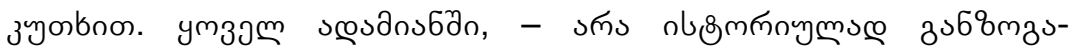

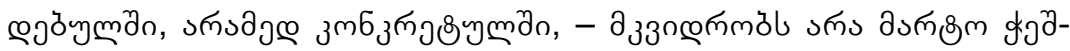

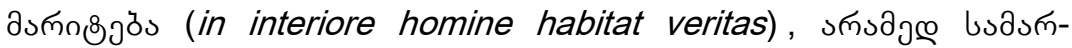

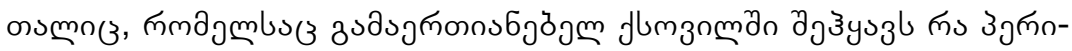

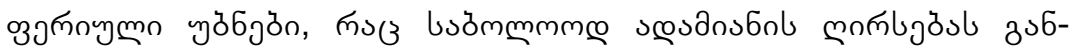

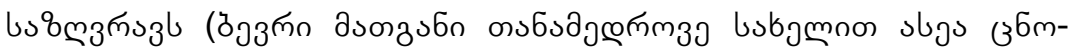

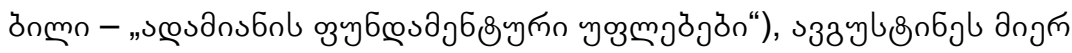

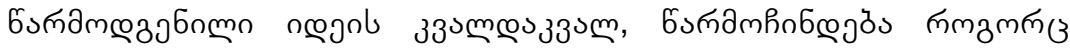

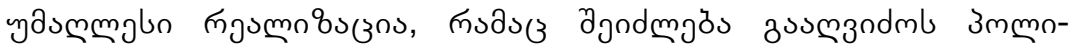

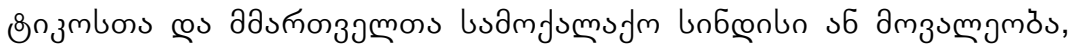

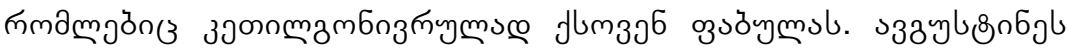

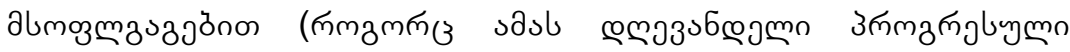

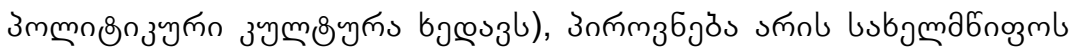

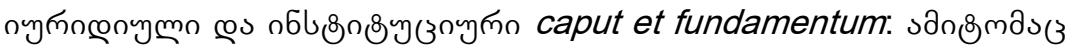

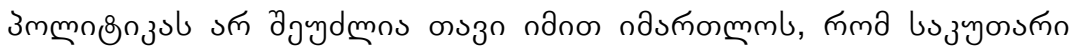

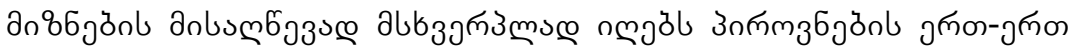

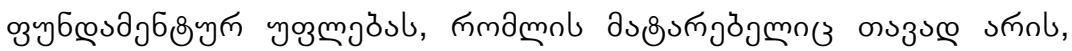

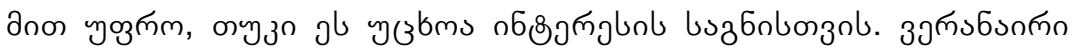

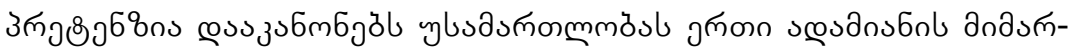

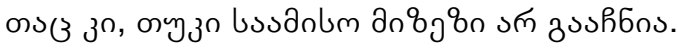

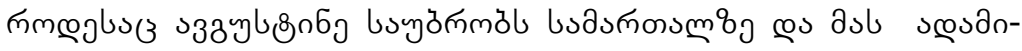

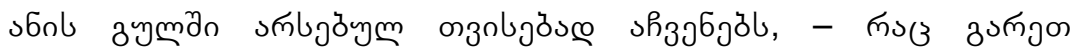
пুлмmo

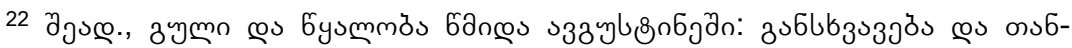
ьзэюп, ,<https://books.google.ge/books?isbn=8831134167GiacomoTantardi ni - 2006> [18.09.2019] 


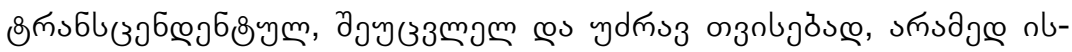

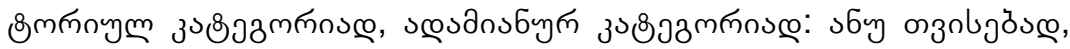

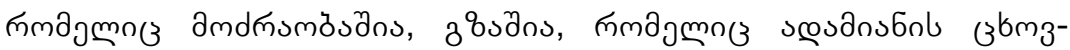

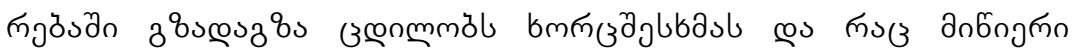

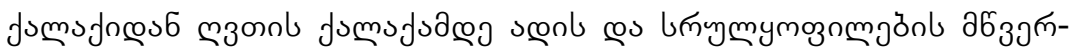
उ.

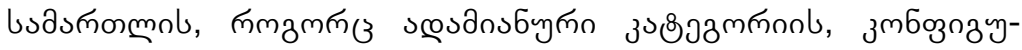

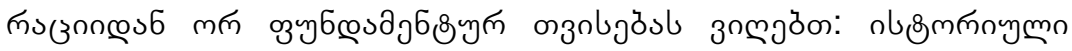

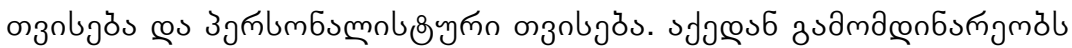

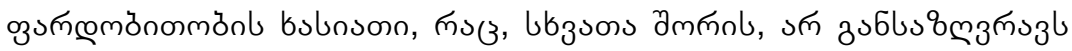

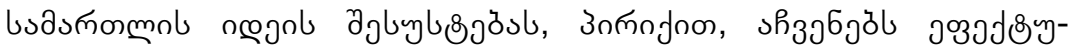

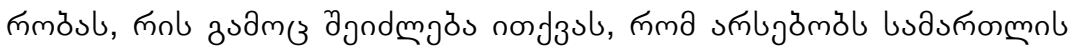

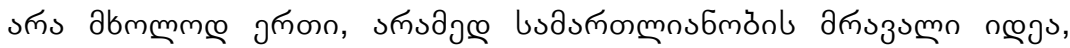

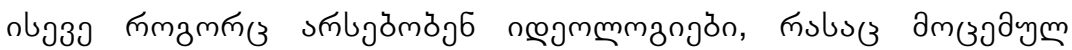

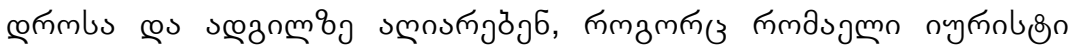

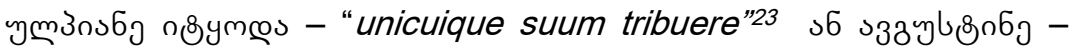
"iuris consensus".

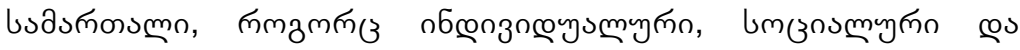

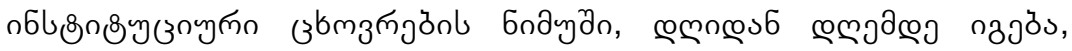

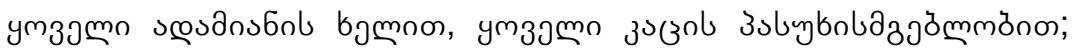

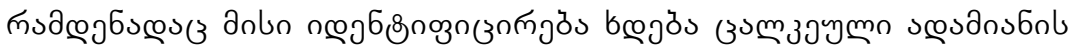

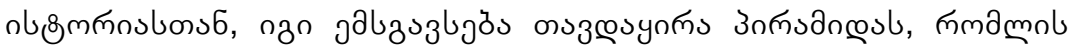

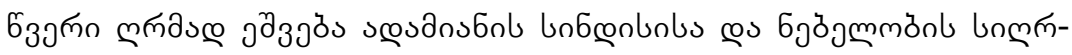

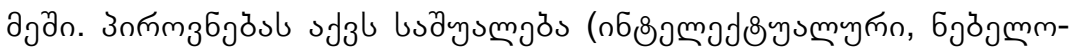

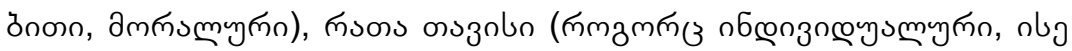

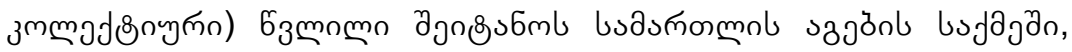

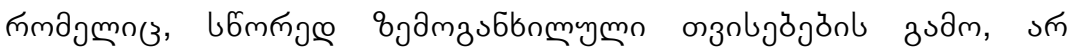

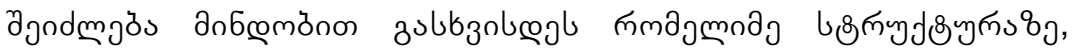

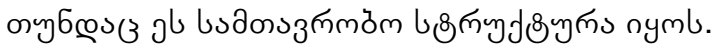

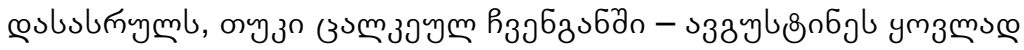

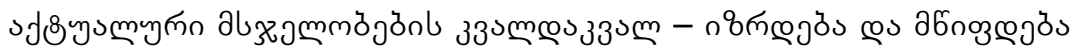

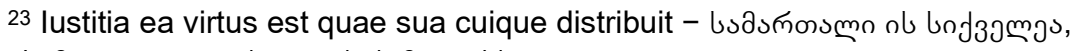

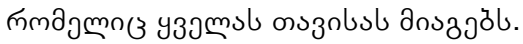




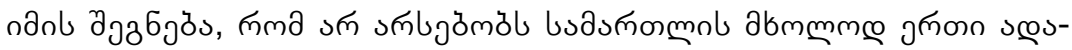

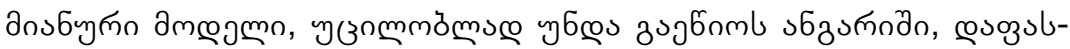

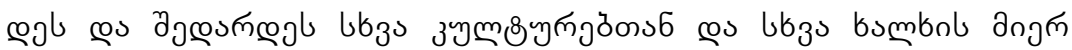

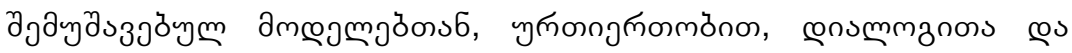

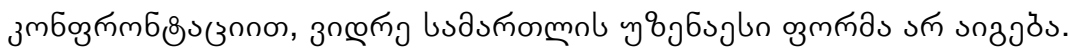

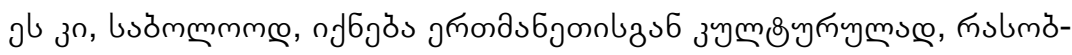

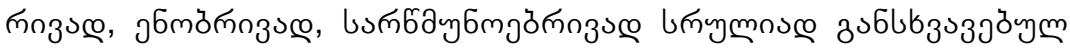

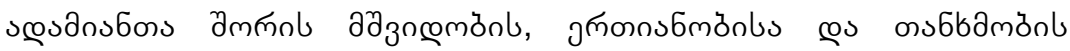

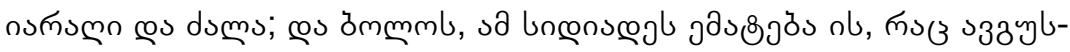

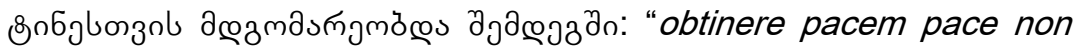

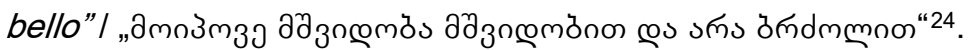

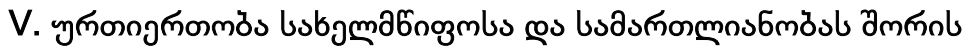

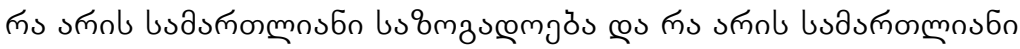

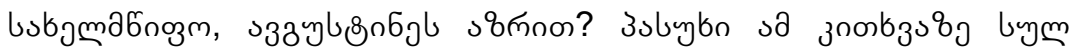

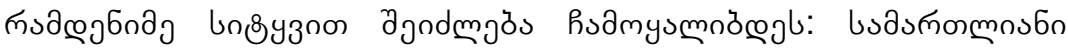

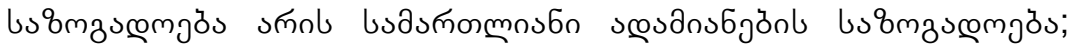

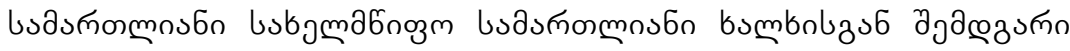

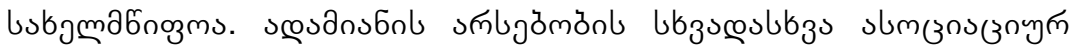

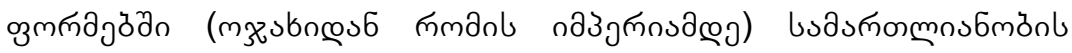

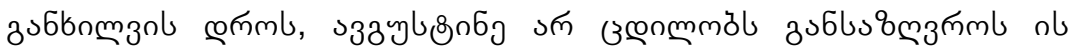

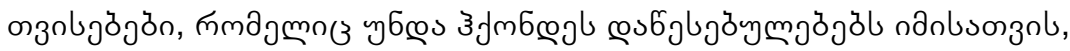

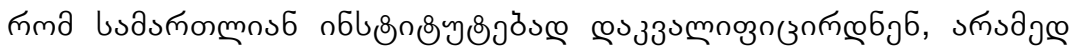

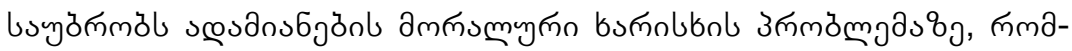

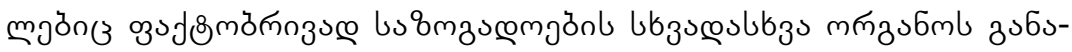

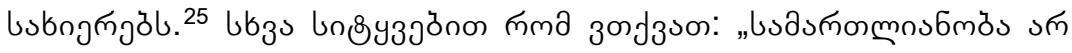

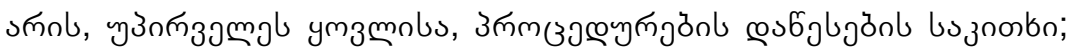

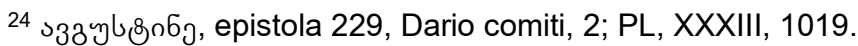

25 sa озง mbs

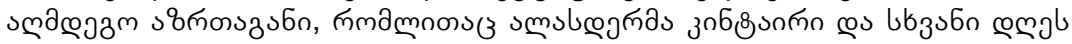

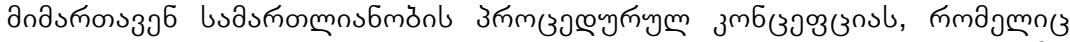

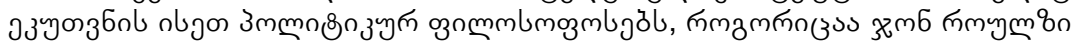

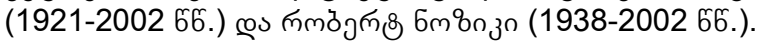




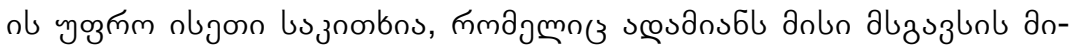

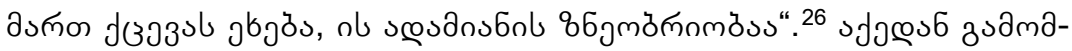

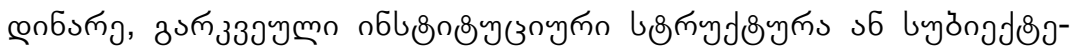

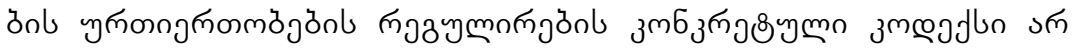

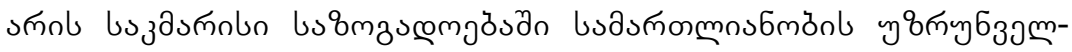

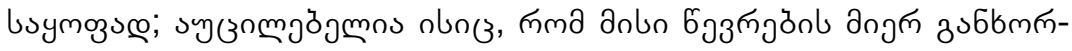

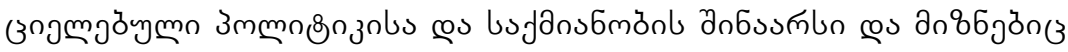

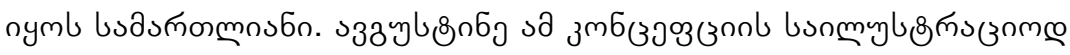

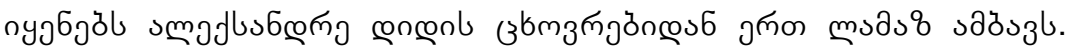

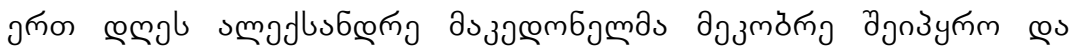

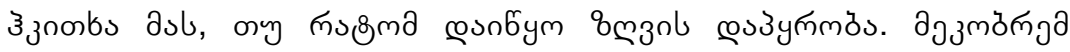

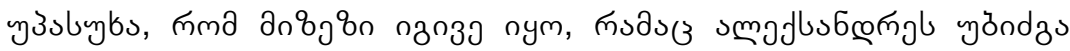

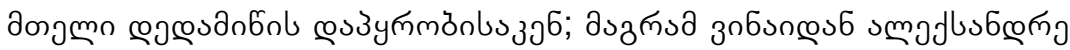

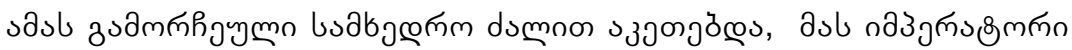

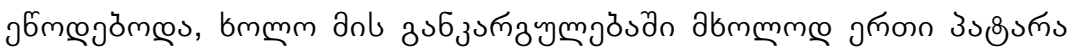

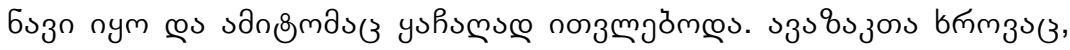

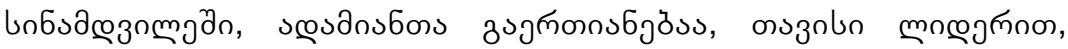

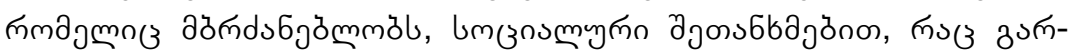

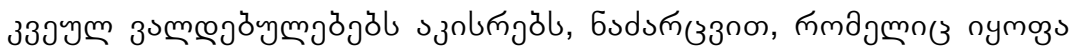

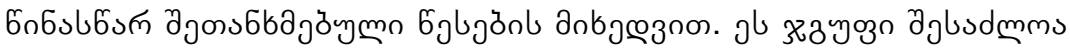

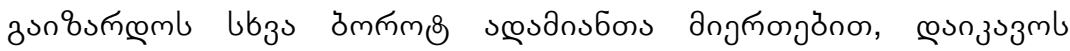

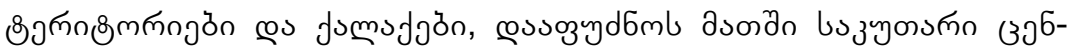

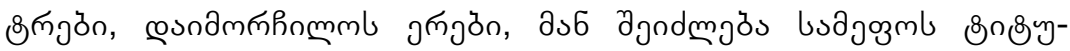

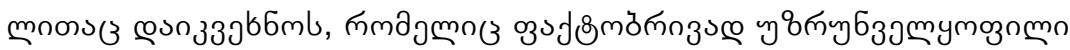

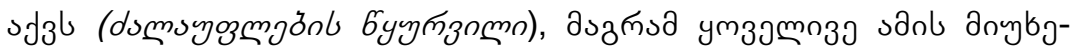

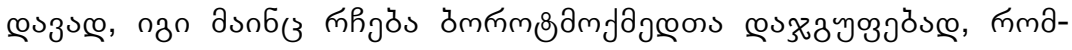

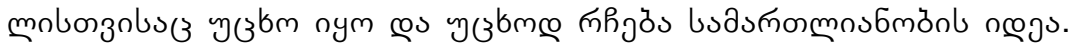

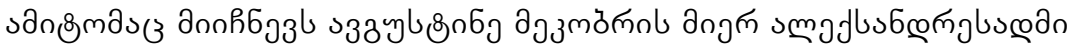

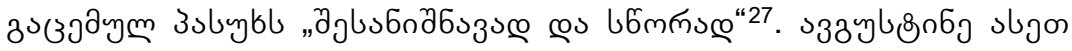

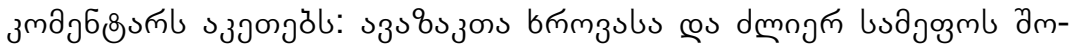

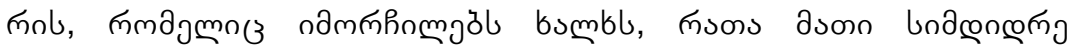

${ }^{26} \mathrm{Da} \operatorname{Re} \mathrm{A}$., Figure dell'etica, in Introduzione all'etica, a cura di C. Vigna, Milano, 2001, 96. Atti dell'Accademia "San Marco" di Pordenone, 20 (2018). $27<$ Cfr. www.30giorni.it > Home > Archivio > 08/09 - 2003> [20.08.2019] 


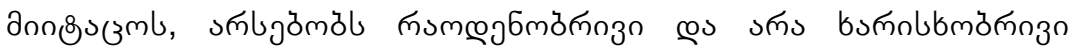

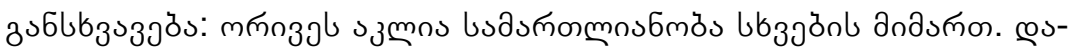

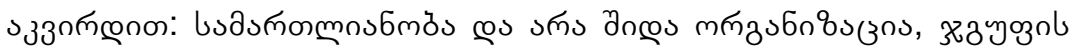
дngп œ১œа

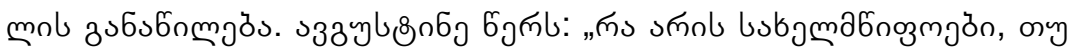

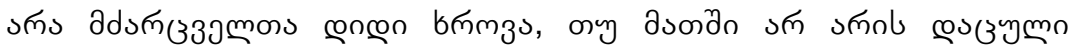
lsasmonmos6mòs?" (Remota ita que iustitia, quid sunt regna nisi

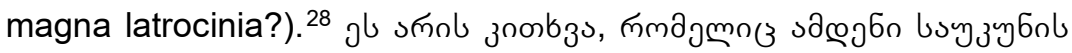

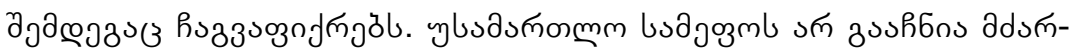

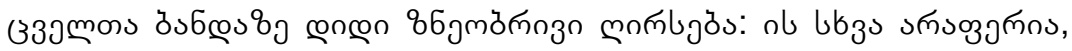

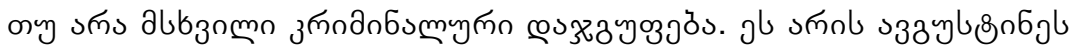

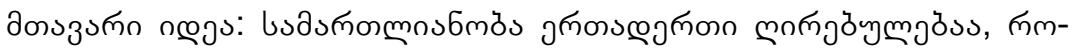

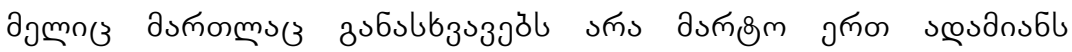

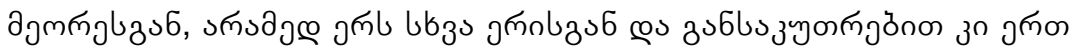

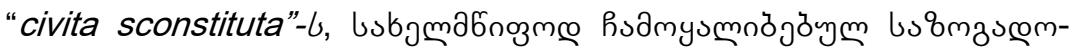

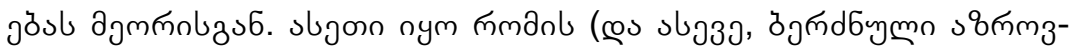

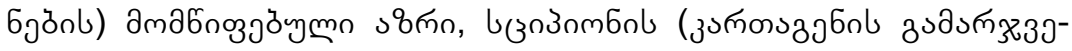

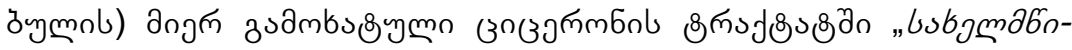

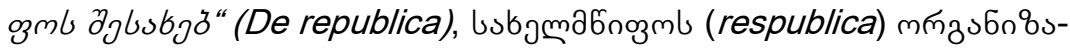

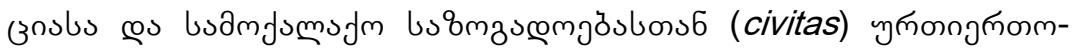
ة

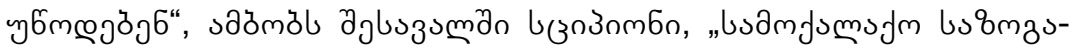

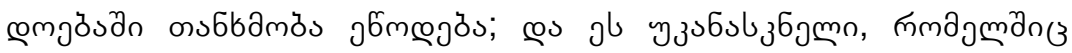

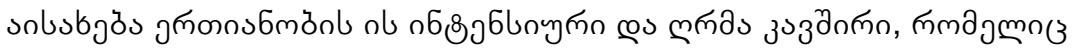

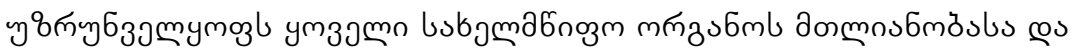

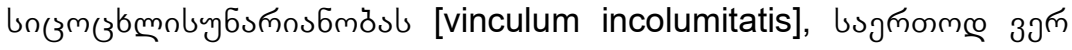

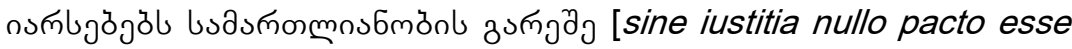

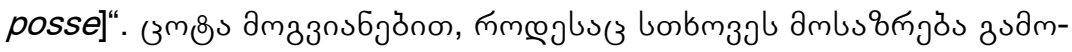

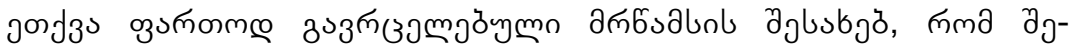

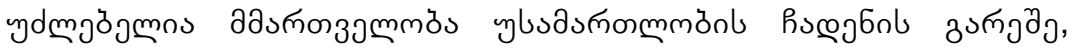

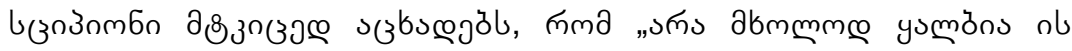

28 Agostino, De civitate Dei, IV, 4. 8 Ivi, II, 21, 2. Atti dell'Accademia "San Marco" di Pordenone, 20 (2018); Catapano G., La giustizia nella sfera pubblica secondo Agostino di Ippona. 


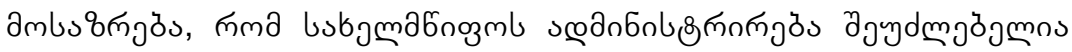

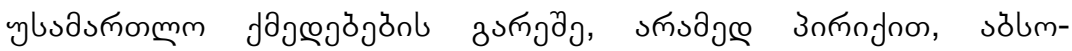

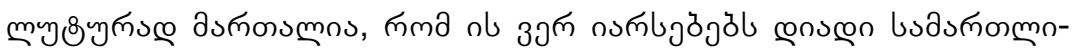

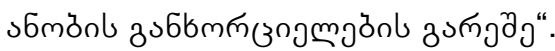

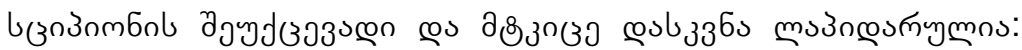

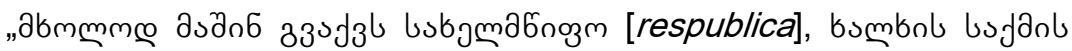

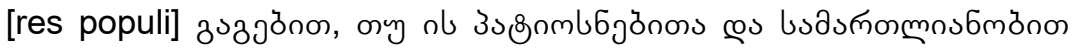

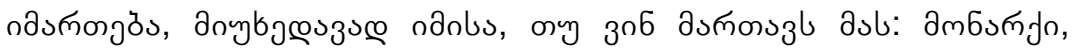

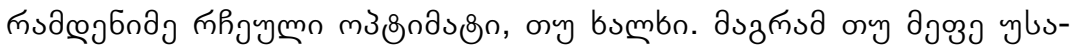

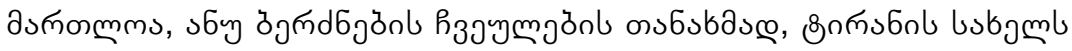
nabskyng

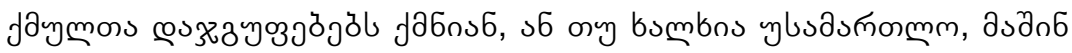

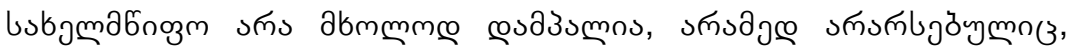

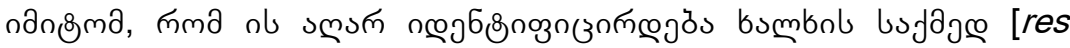

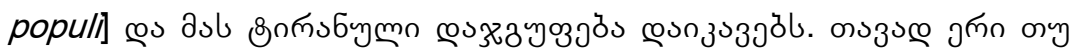

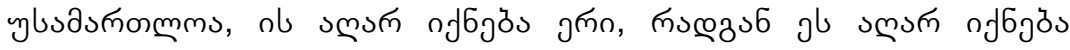

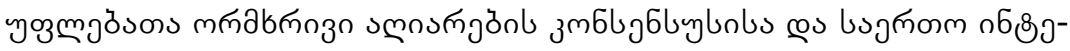

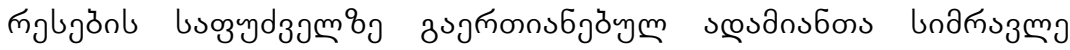
[multitudo iuris consensu et utilitas communione societa]“. إ nœ9-

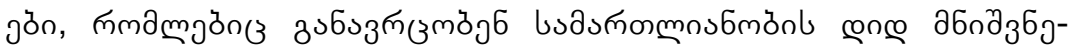

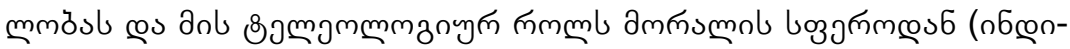

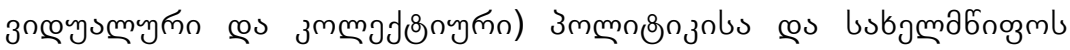

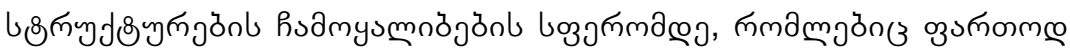

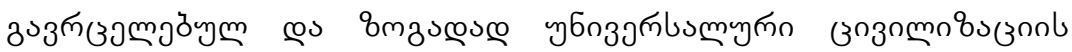

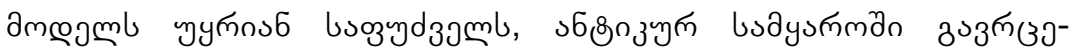

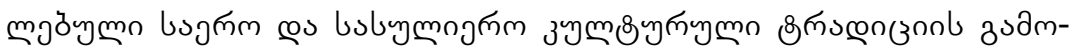

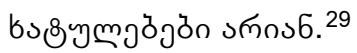

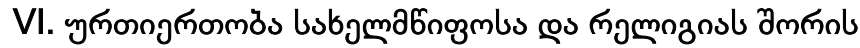

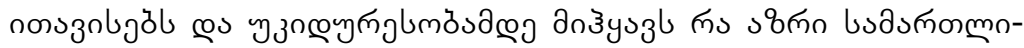

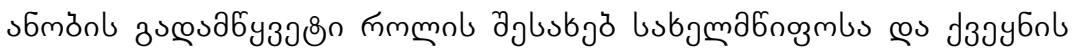

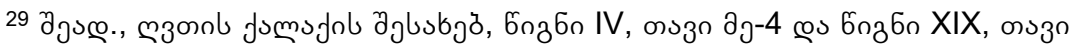
21-o, Cfr. libro IV, capitolo 4 e libro XIX, capitolo 21 del De civitate Dei. 


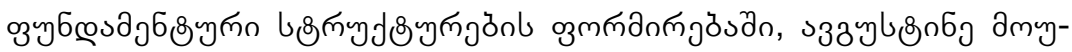

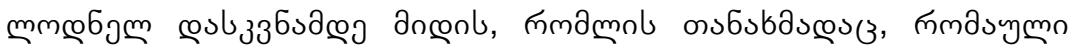

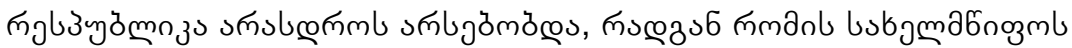

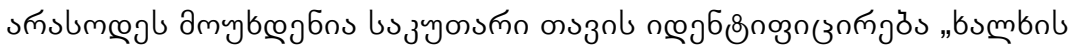

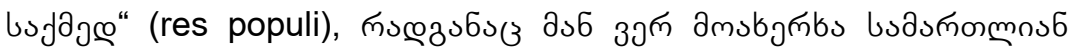

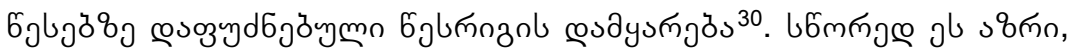

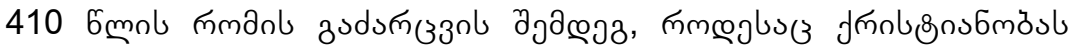

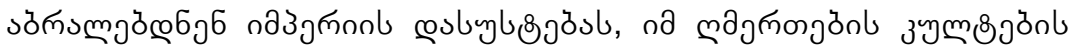

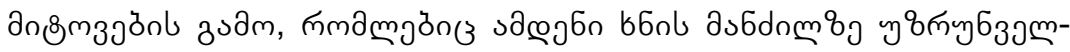

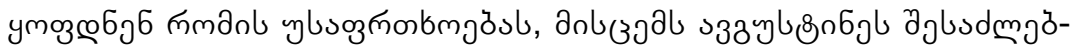

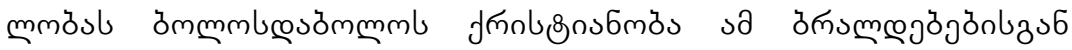

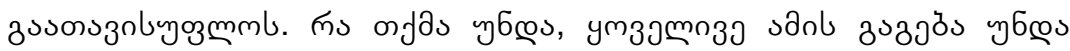

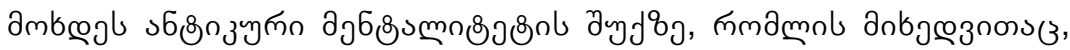

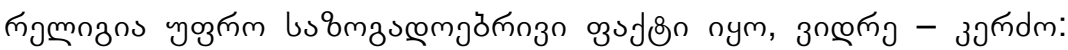

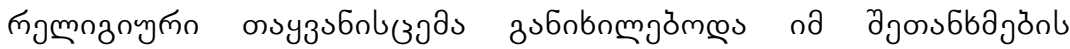

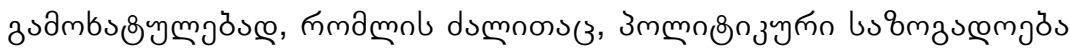

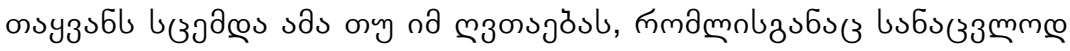

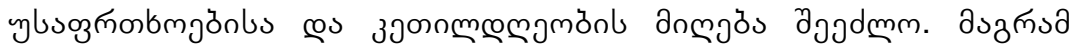

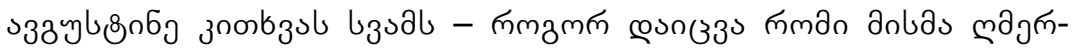

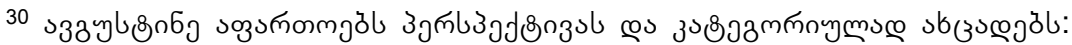
"ubi non est vera iustitia, iuris consensu sociatus coetus hominum non potest esse et ideo nec populus iuxta illam Scipionis vel Ciceronis definitionem; et si non populus, nec res populi, sed qualiscumque multitudinis quae populi nomine digna non est. Ac per hoc, si res publica res est populi et populus non est qui consensu non sociatus est iuris, non est autem ius ubi nulla iustitia est: procul dubio colligitur, ubi iustitia non est non esse rem publicam"

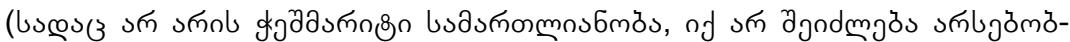

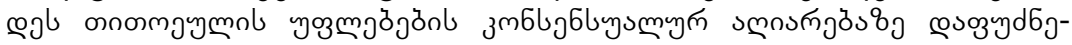

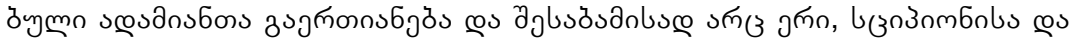

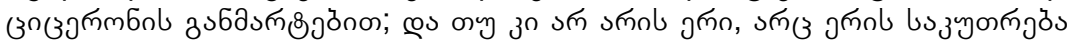

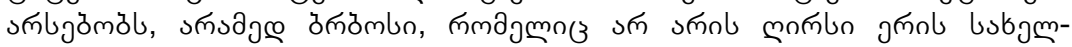

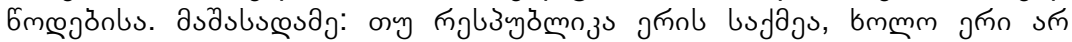

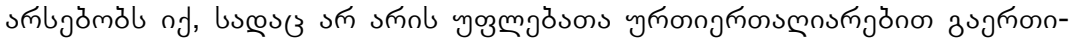

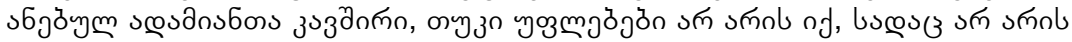

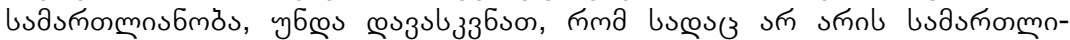

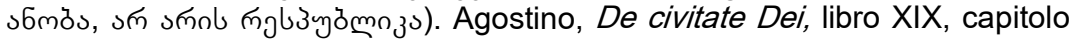
XXI, pp. 687-688. 


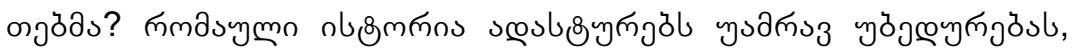

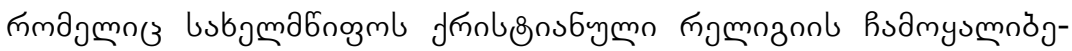

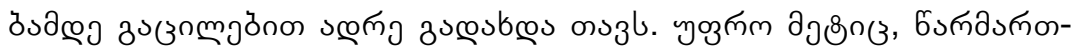

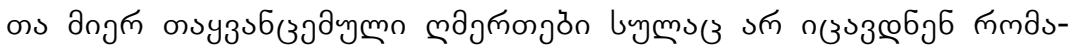

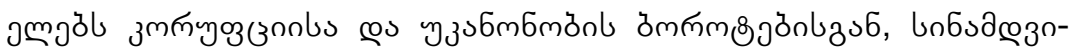

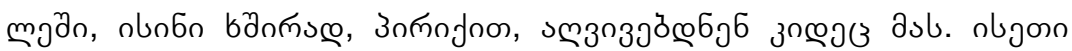

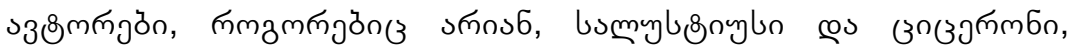

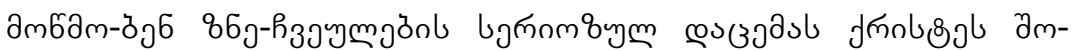

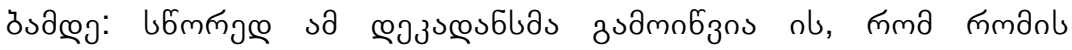

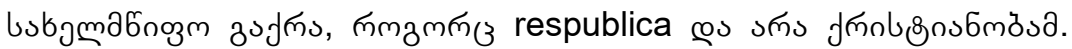

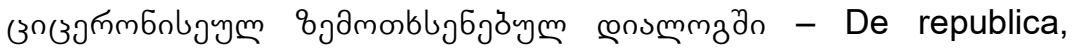

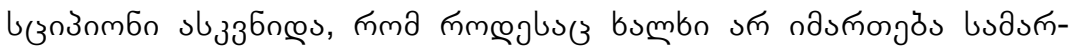

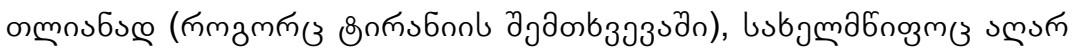

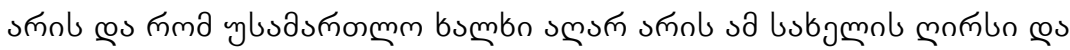

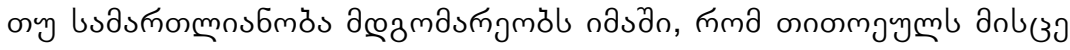

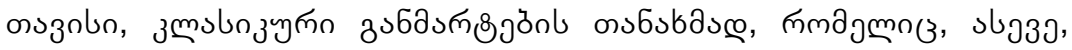

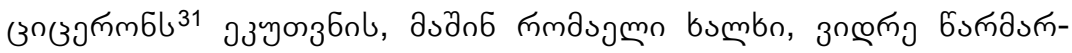

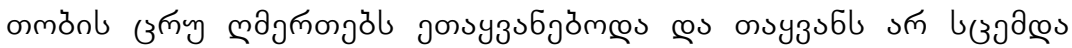

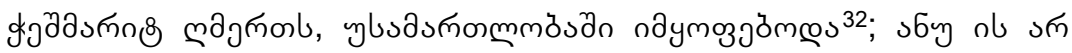

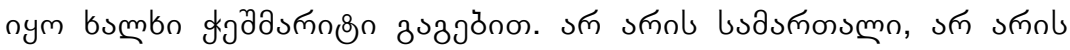

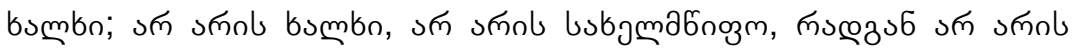

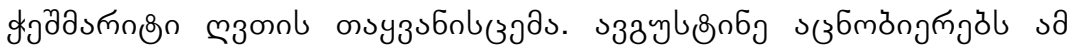

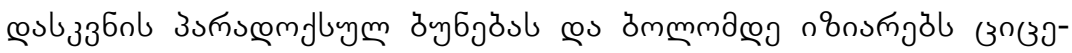

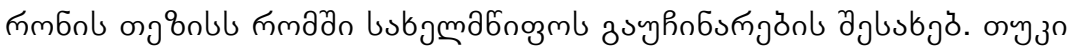

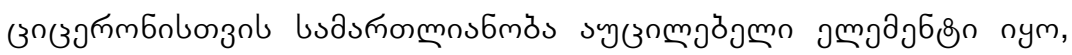

31 Cicerone, Deinventione, II, 53, 159-160.

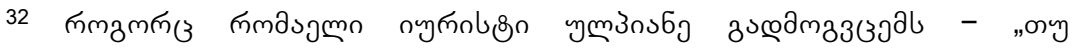

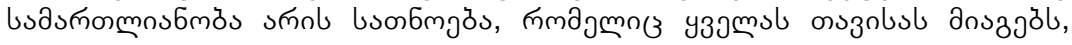
liustitia ea virtus est, quae sua cuique distribuitt asd bs@ smol

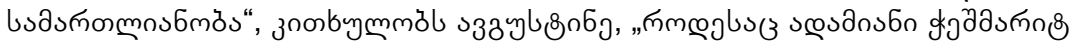

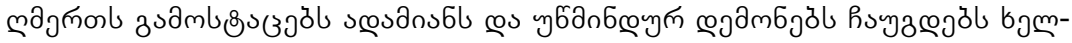

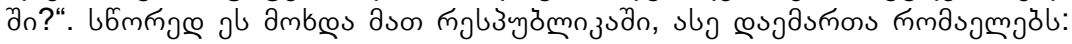

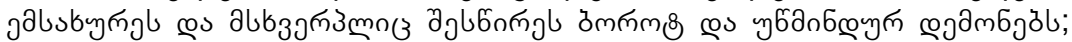

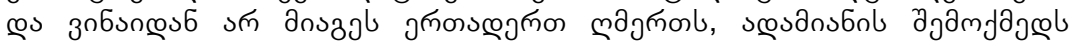
oszoln, ason sm smoungl bsasmosumn. 


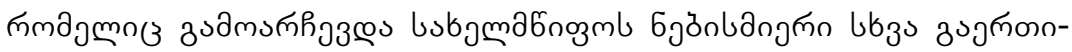

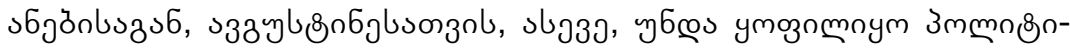

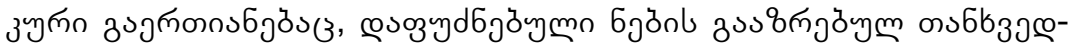

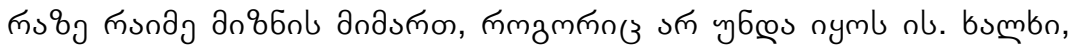

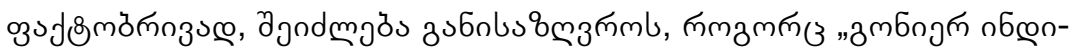

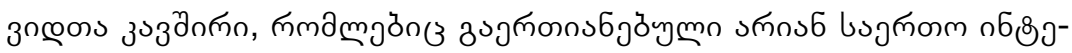

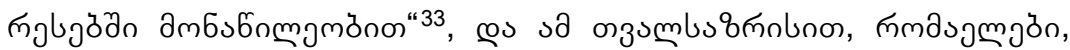

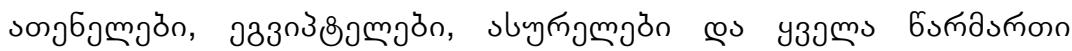

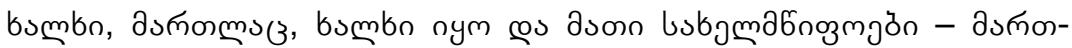

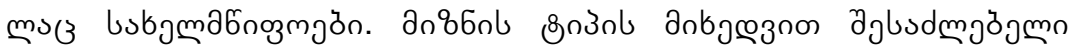

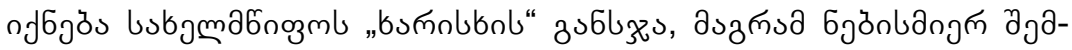

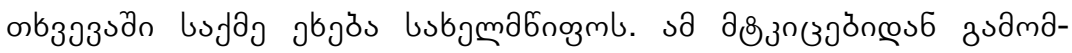

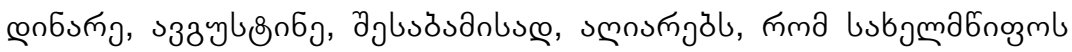

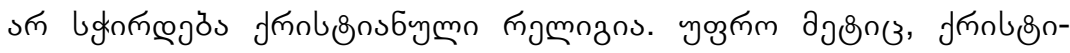

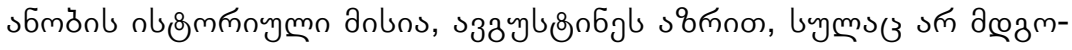

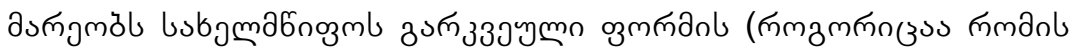

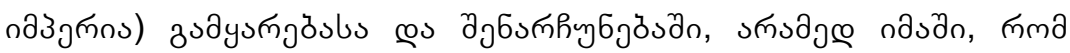

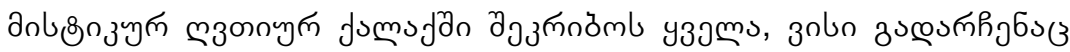

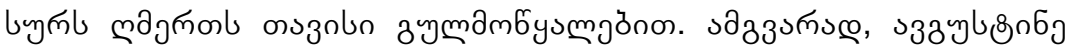

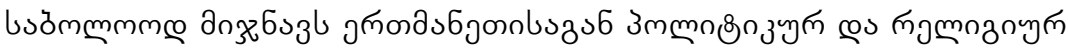

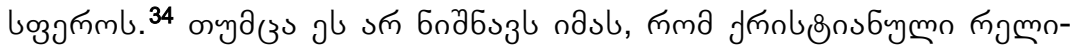

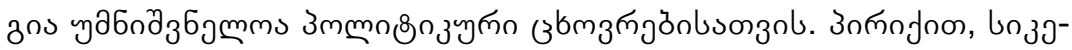

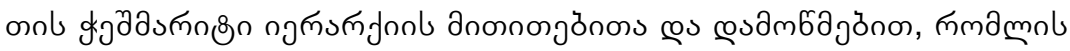

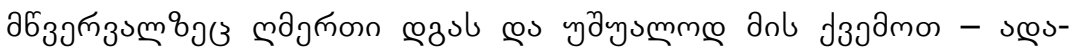

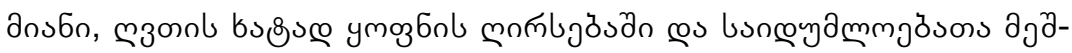

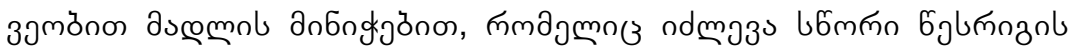

33 Agostino, De civitate Dei, XIX, 24: Populus est coetus multitudinis rationalis rerum quas diligit concordi communione sociatus.

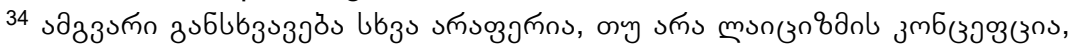

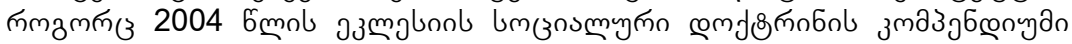

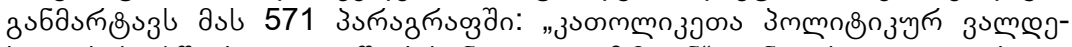

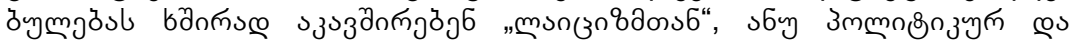

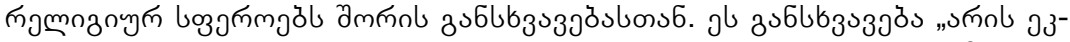

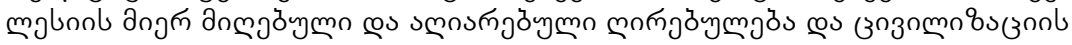

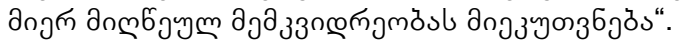




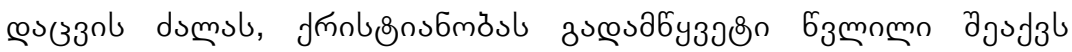

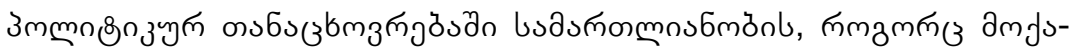
msjjons bsonbmjönl, na lsogydzmol y

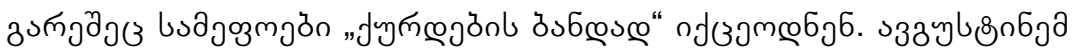

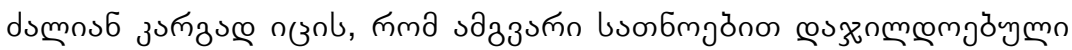
amfums

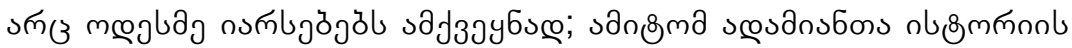

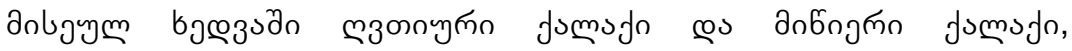

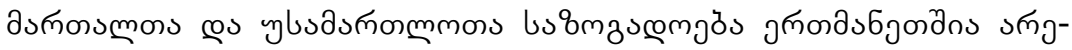

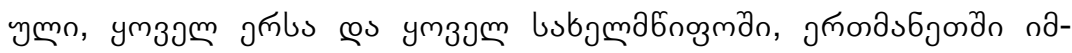

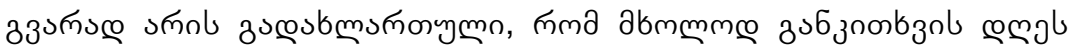
joydmos doln zubl6s. ${ }^{35}$

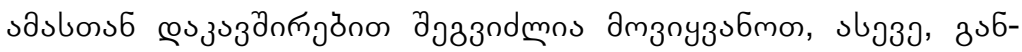

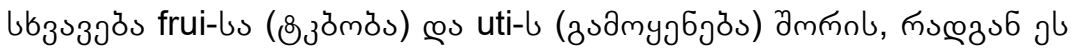

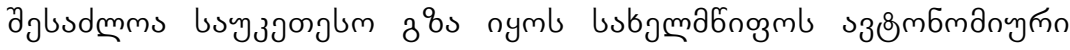

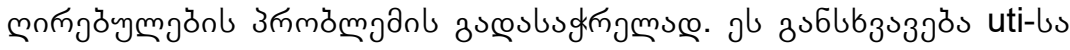

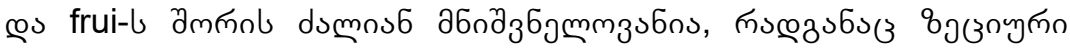

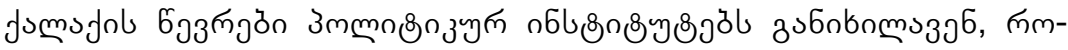

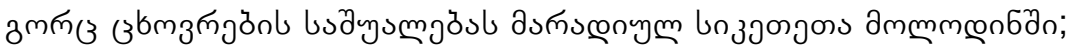

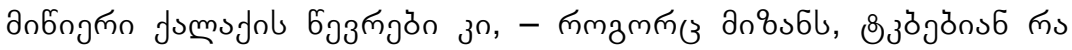

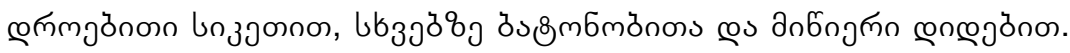

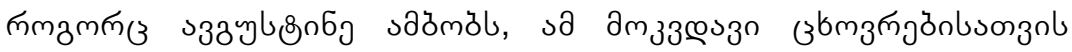

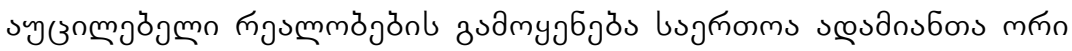

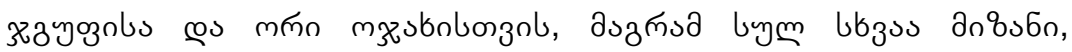

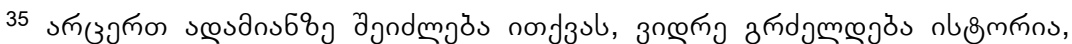

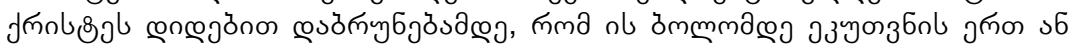

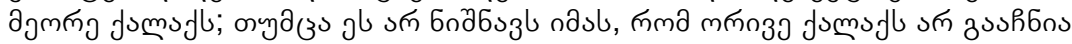

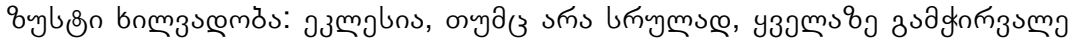

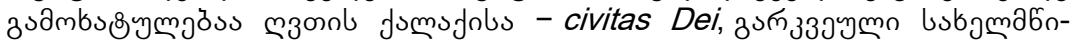

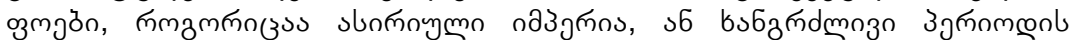

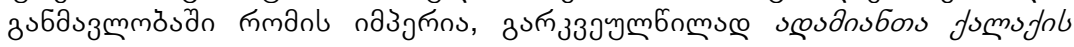
- civitas hominum zuambs৪ymmỏss. 


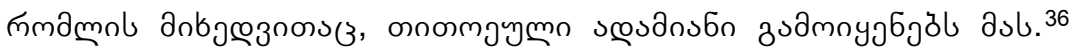

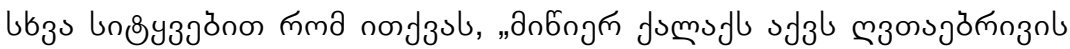

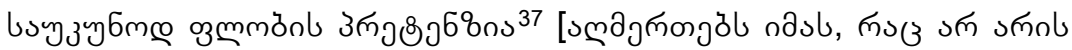

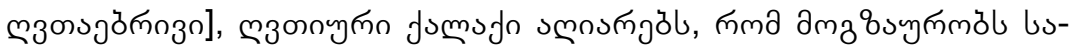

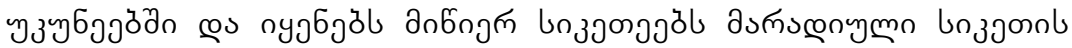

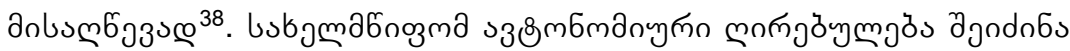

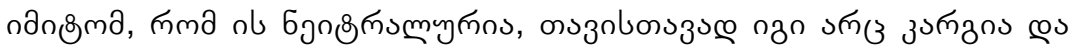

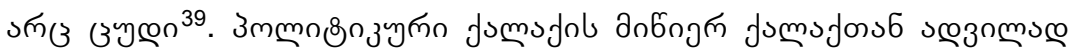

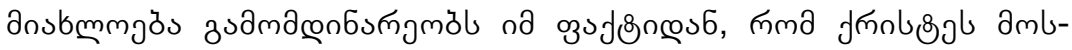

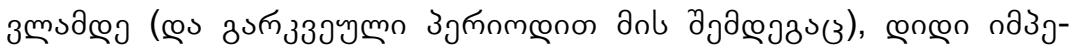

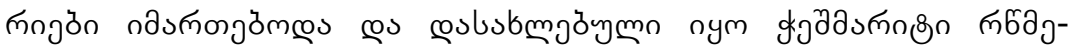

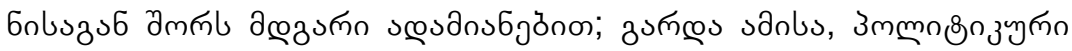

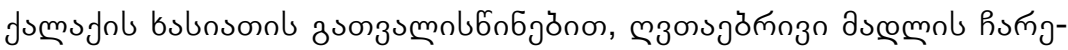

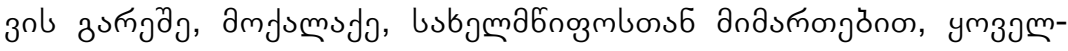

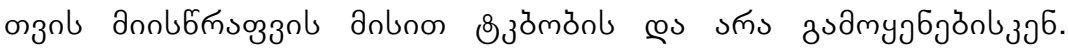

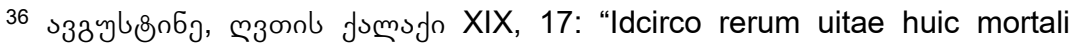
necessariarum utrisque hominibus et utrique domui communis est usus; sed finis utendi cuique suus proprius multumque diuersus".

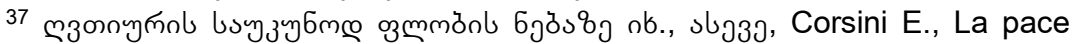
nella "Città di Dio" di S. Agostino, Civiltà classica e cristiana, Genova, 2,

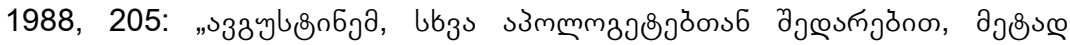

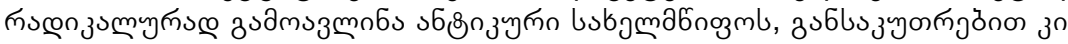

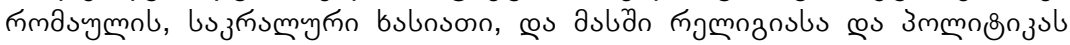

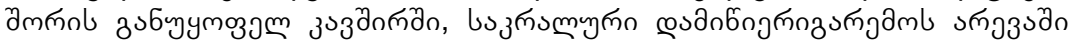

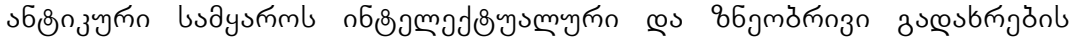

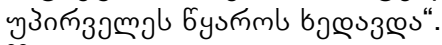

38 josœ., Lettieri G., Riflessioni sulla teologia politica in Agostino, in: II Dio mortale: teologie politiche tra antico e moderno, a cura di Paolo Bettiolo e Giovanni Filoramo, Brescia, Morcelliana, 2002, 217.

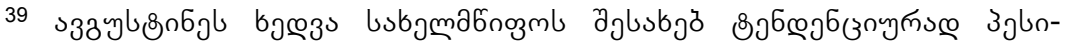

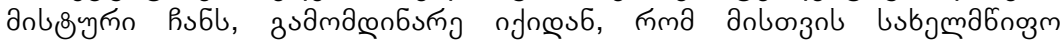

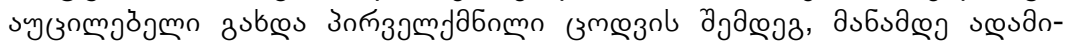

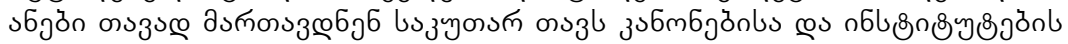

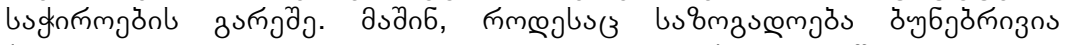

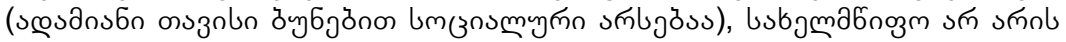

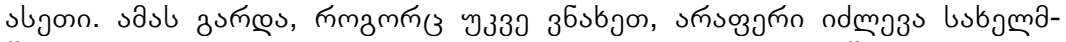

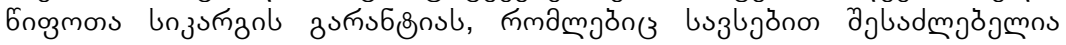

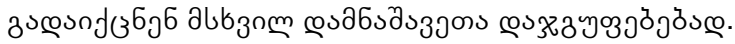




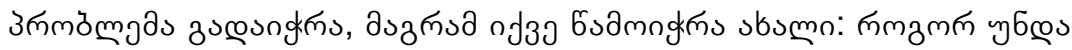
amnjugl bubjmabnozm mjmnznym bubnsonol buznombjöms6

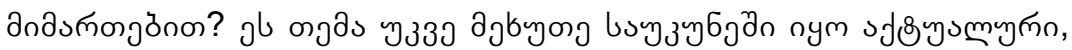

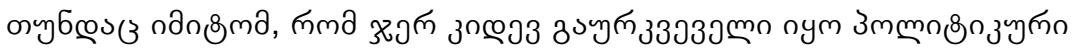

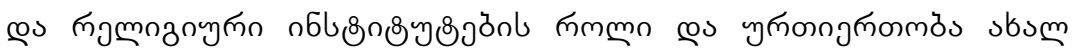

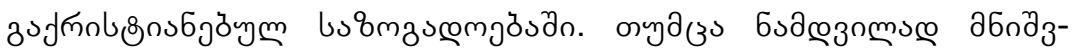

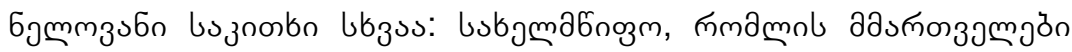

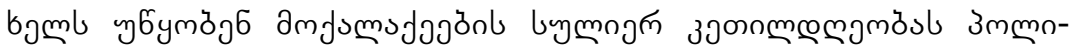

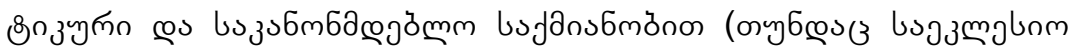

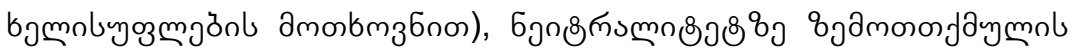

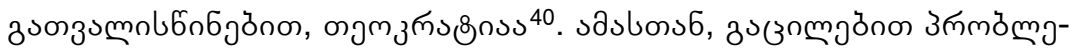

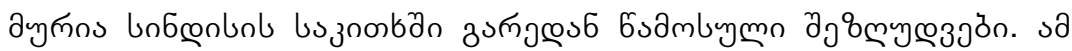

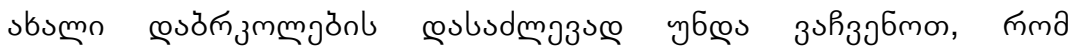

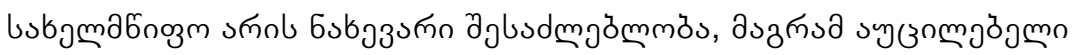

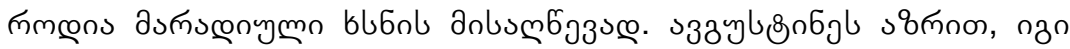

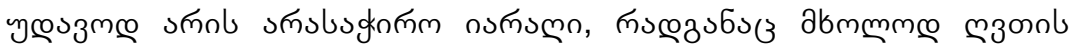

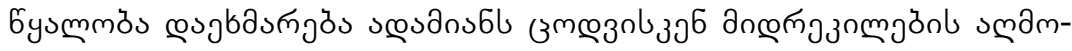

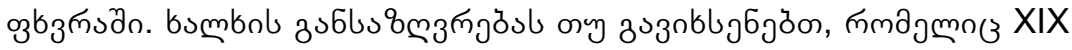

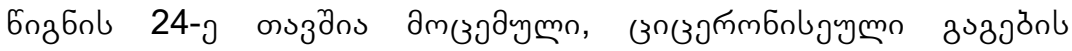
งм৪ి

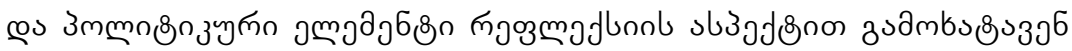

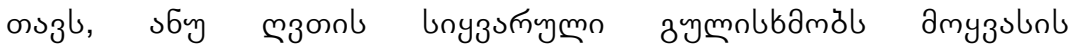

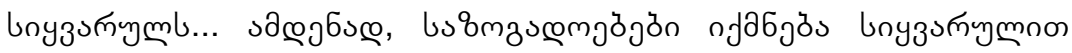

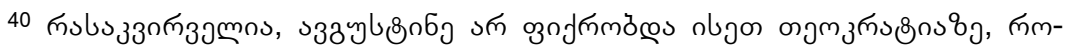

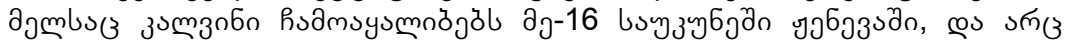

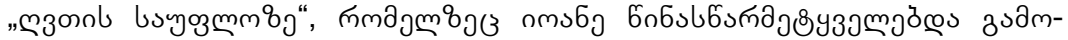

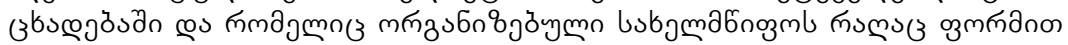

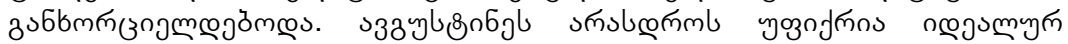

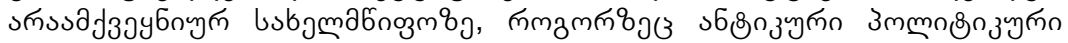

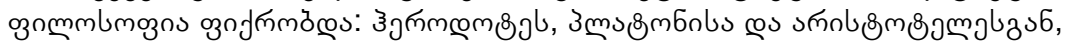

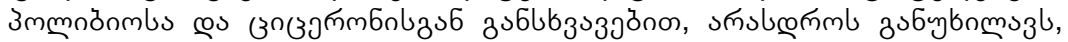

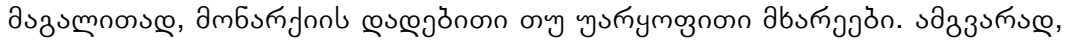

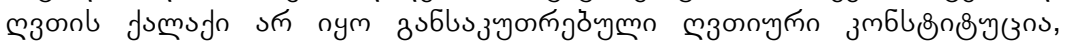

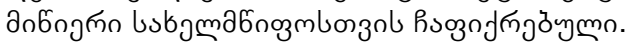

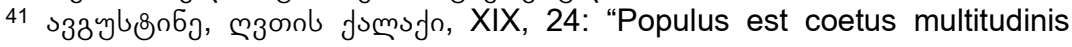
rationalis rerum quas diligit concord communione sociatus". 


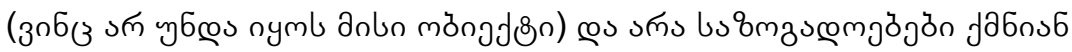

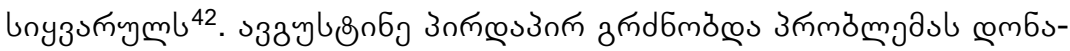

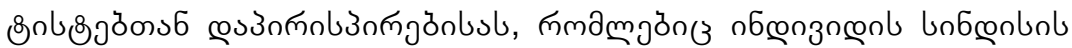

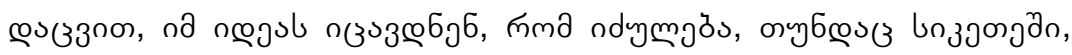

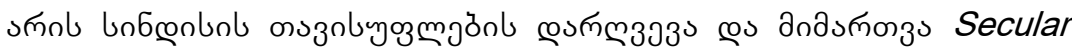

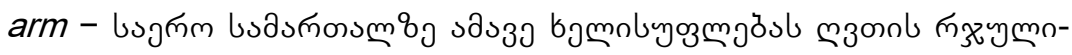

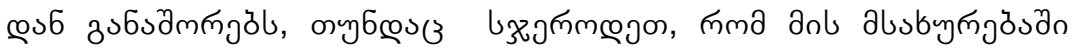
œ3ง6ง6. ${ }^{43}$

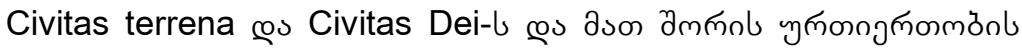

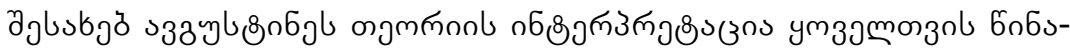

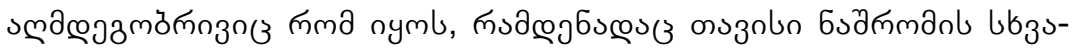

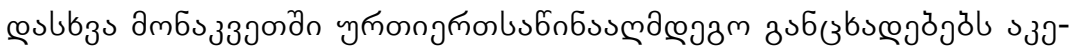

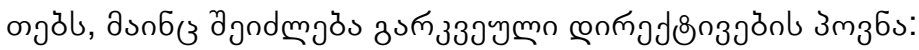

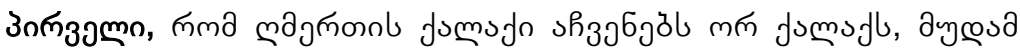

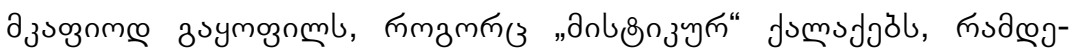

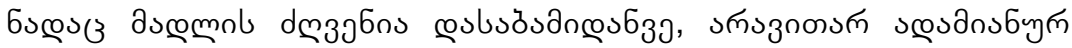

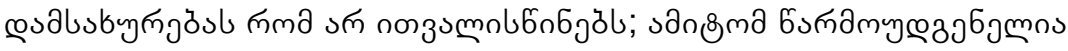

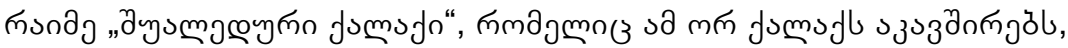

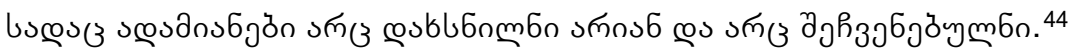

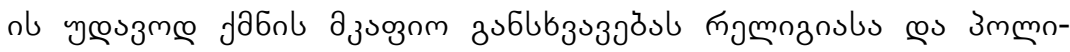

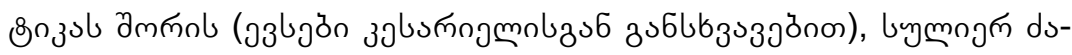

42 Әəงœ., Cotta S., La città politica di sant'Agostino, Milano, 1960, 100.

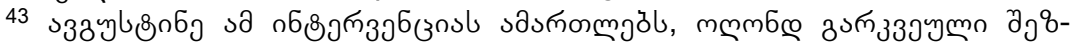

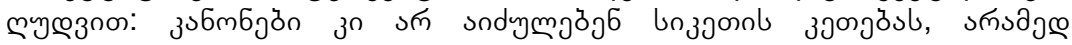

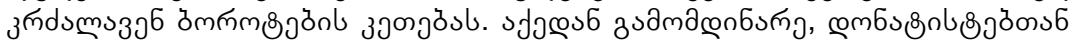

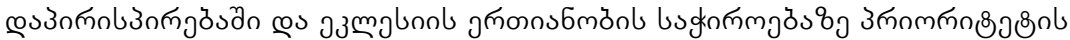

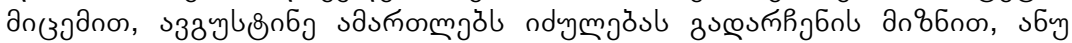

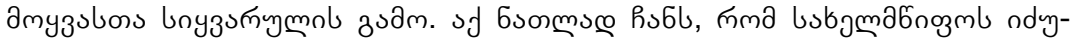

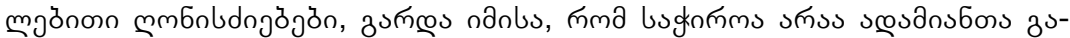

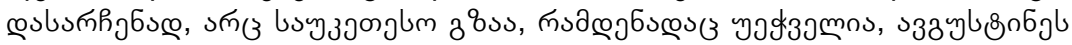

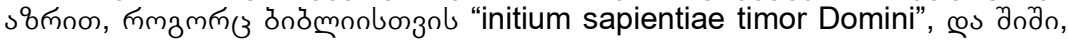

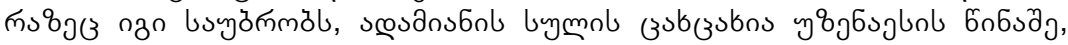

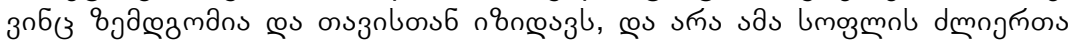

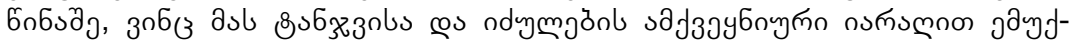
mुלेs.

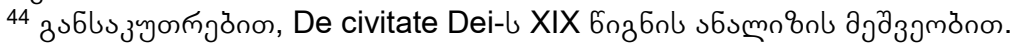




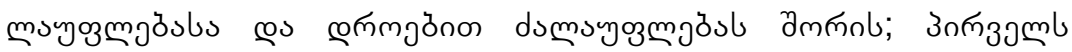

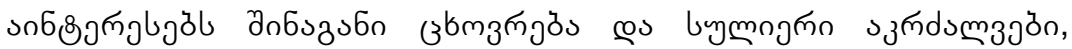

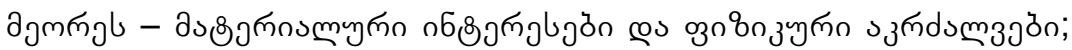

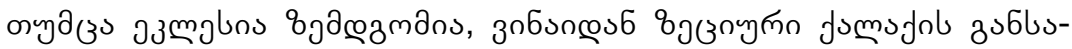

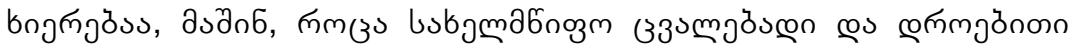

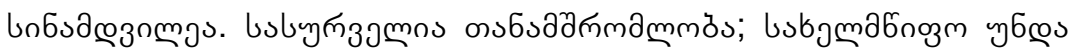

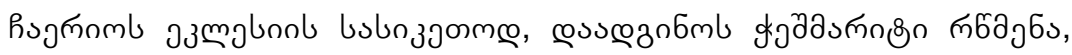

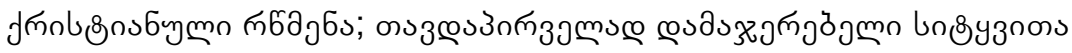

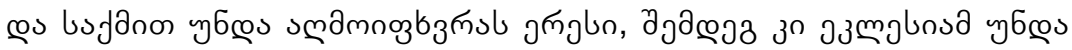

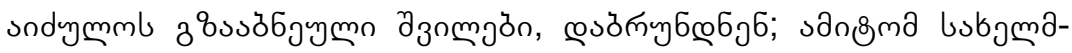

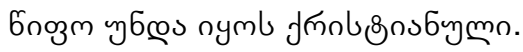

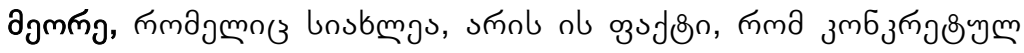

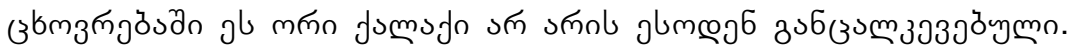

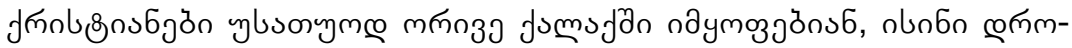

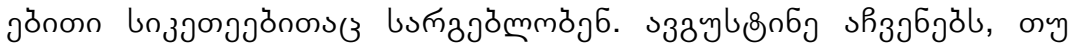

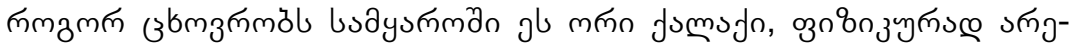

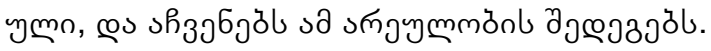

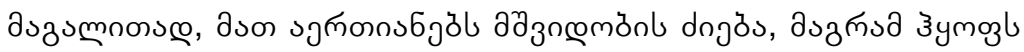

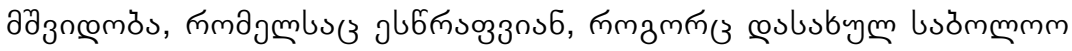

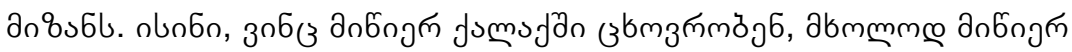

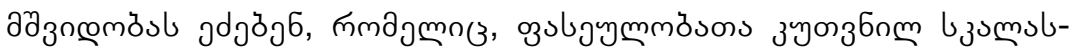

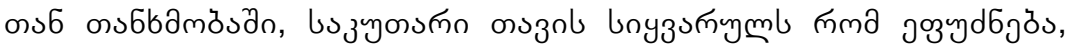

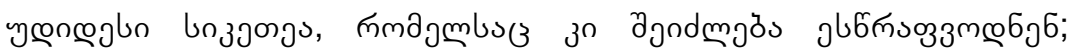

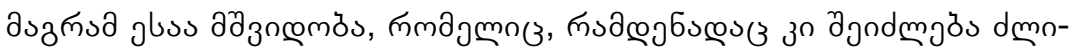

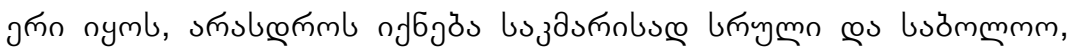

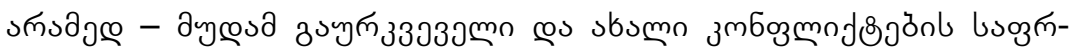

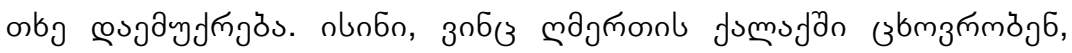

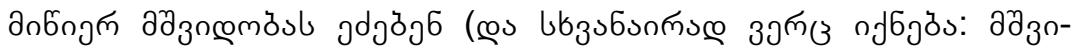

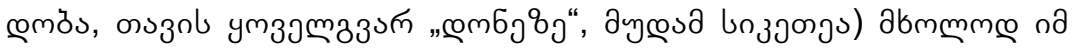

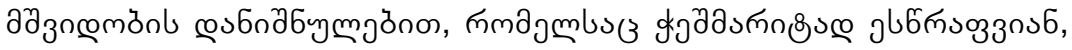

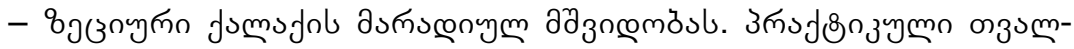

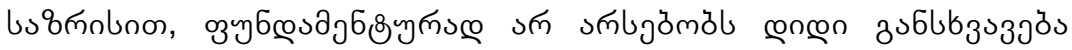

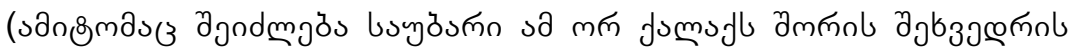

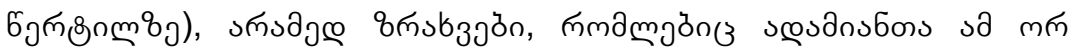




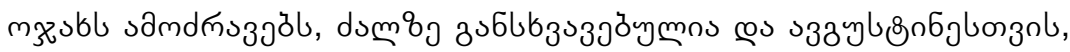

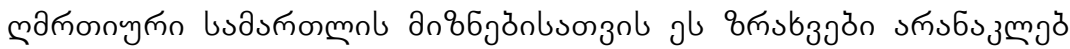

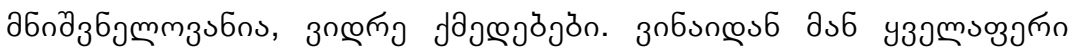

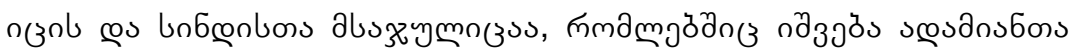

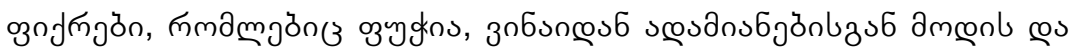

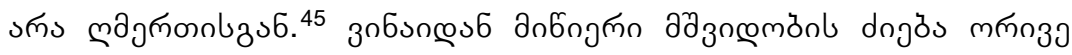

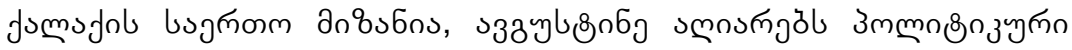

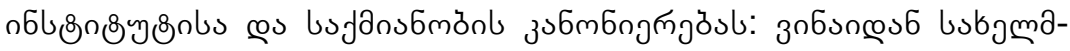

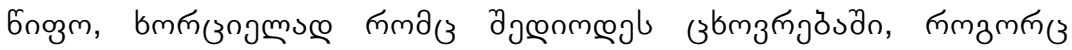

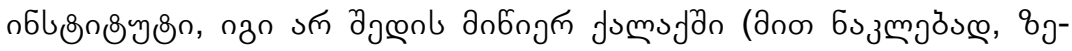

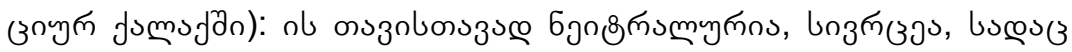

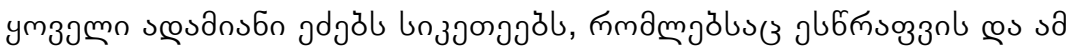

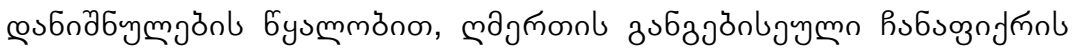

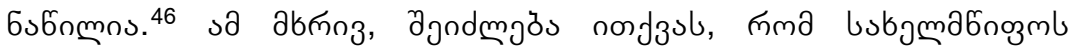

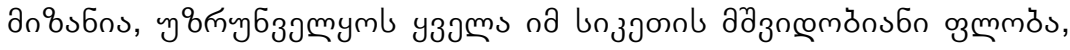

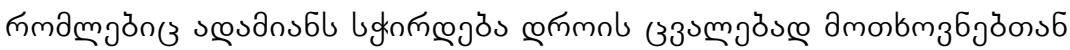

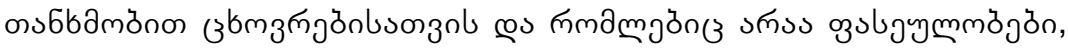

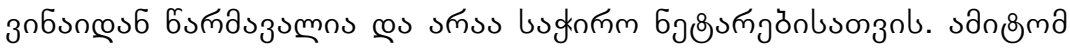

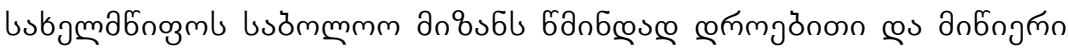

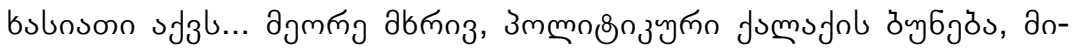

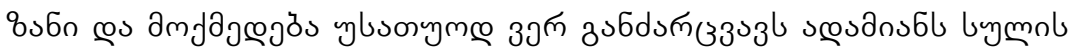

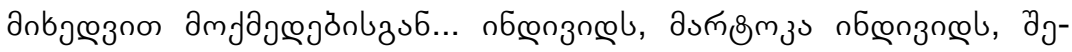

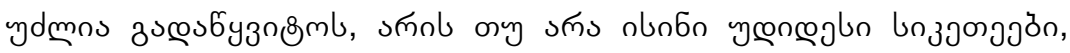

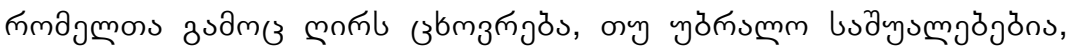

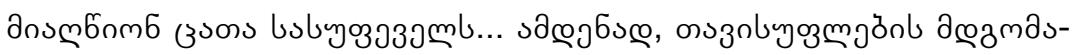

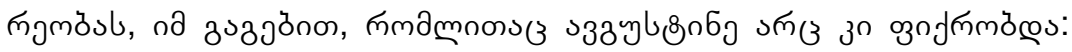

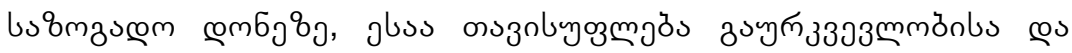

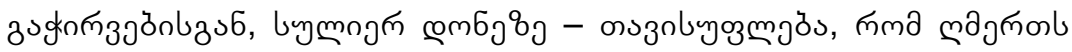

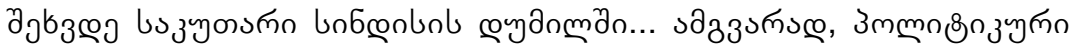

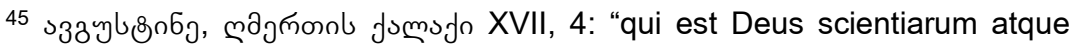
ideo et arbiter coscientiarum, ibi uidens cogitationem hominum, quoniam humanae sunt, si hominumsunt et ab illo non sunt".

46 jəऽœ.., Pellegrino M., Fede e morale nella visione politica di Sant'Agostino, Studia Patavina, 25, 1978, 500. 


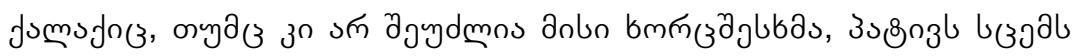

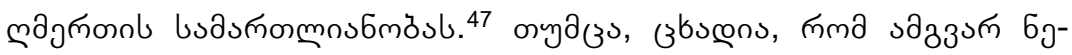

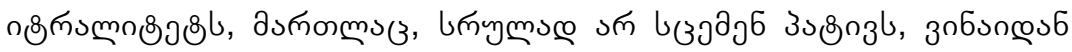

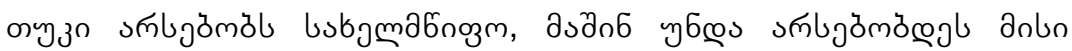

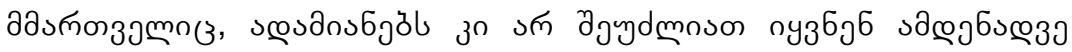

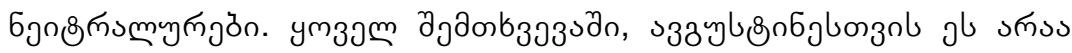

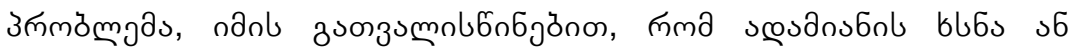

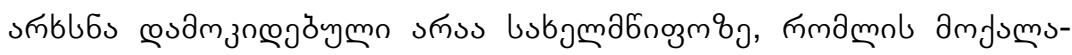

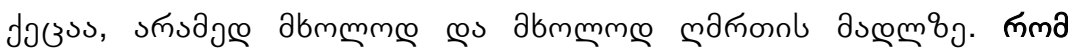

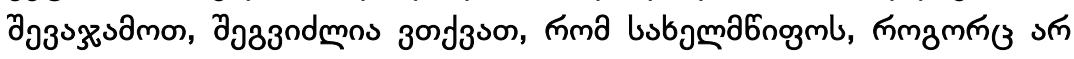

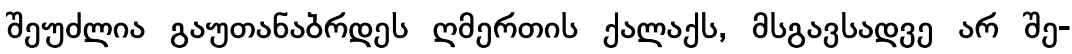

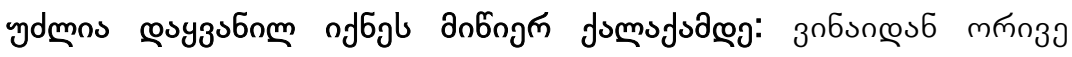

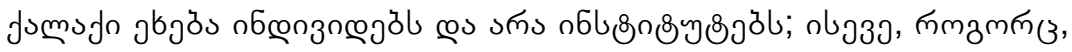

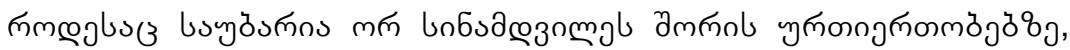

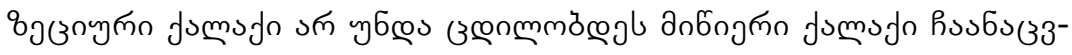

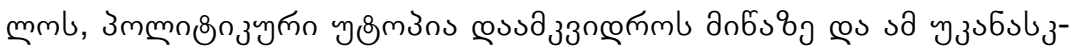

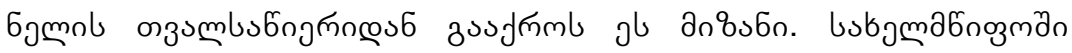

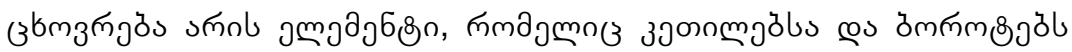

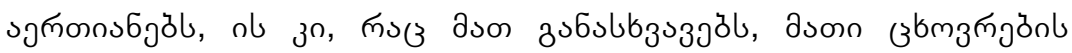
6jlos.

\section{VII. $\operatorname{col}_{33} 6 \mathrm{~s}$}

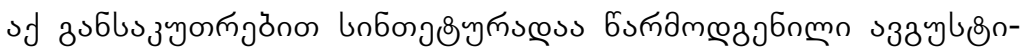
6 b

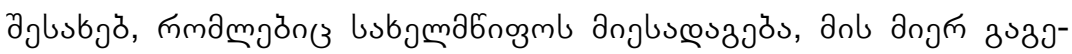

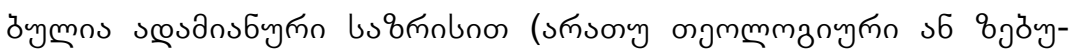

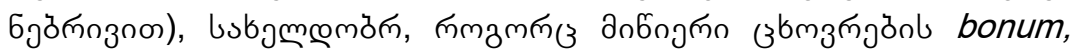

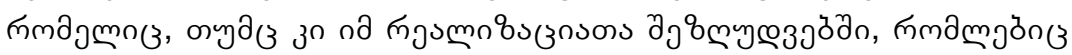

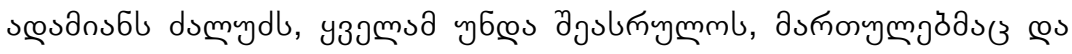

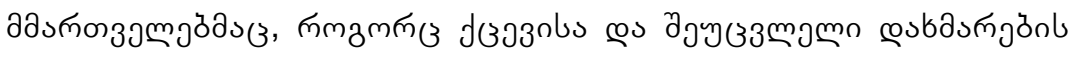

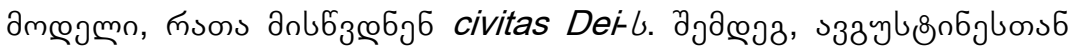

47 yjuœ., Cotta S., La città politica di sant'Agostino, Milano, 1960, 172-173. 
п̆mmaznuls (

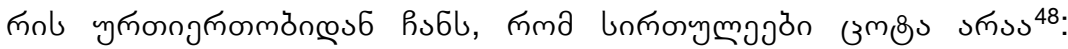

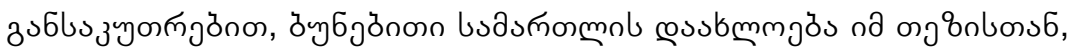

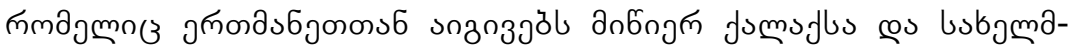

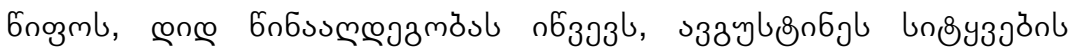

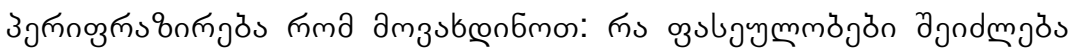

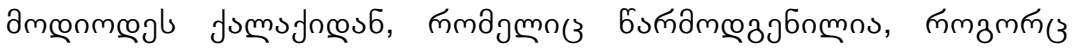

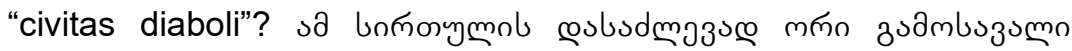

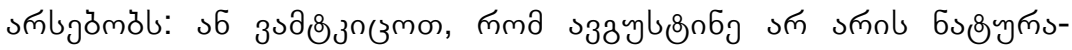

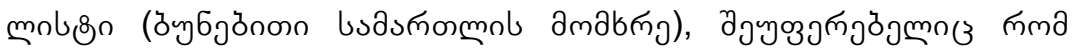

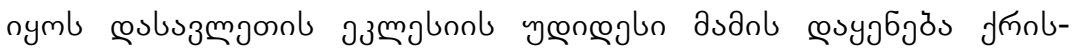

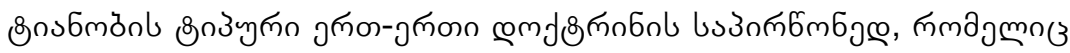

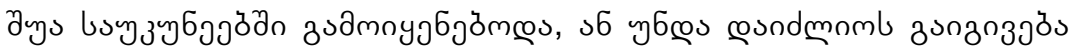

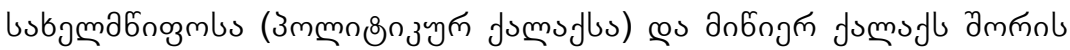

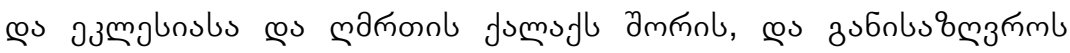

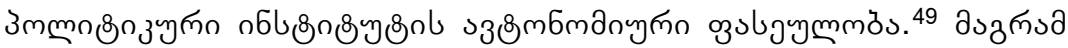

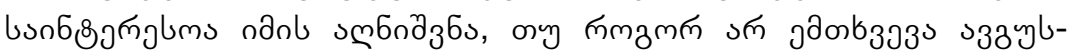

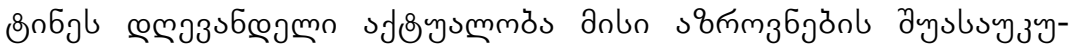

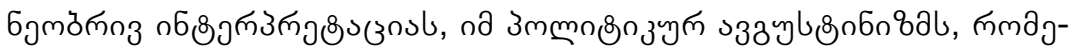

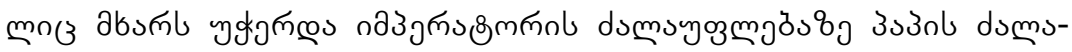

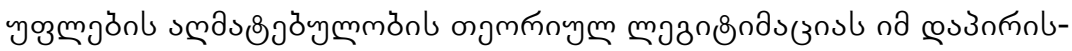

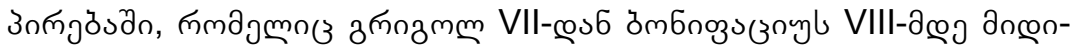

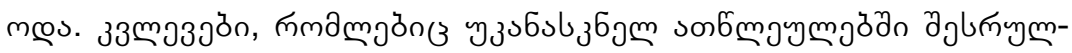

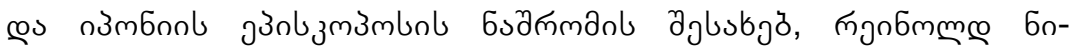

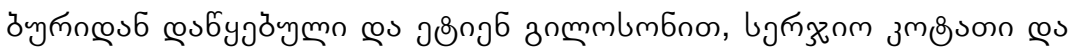

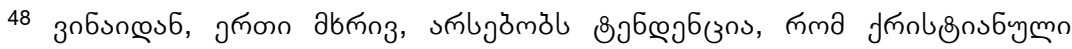
andm3ng

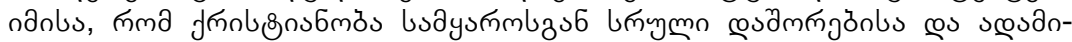

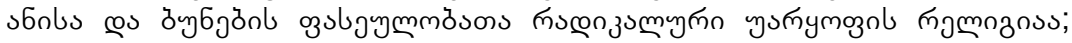

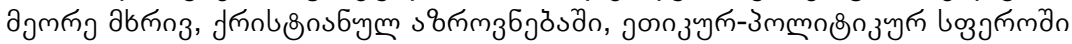

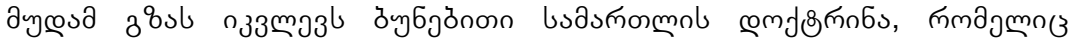

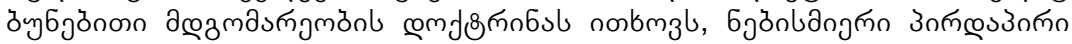

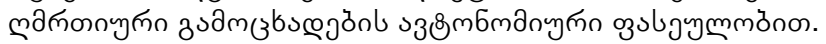

$49<$ www.academia.edu/.../il rapporto tra le due città nel libro XIX della Città di Dio> [15.08.2019] 


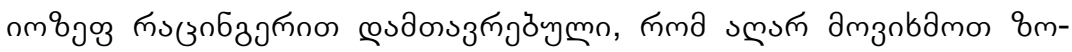

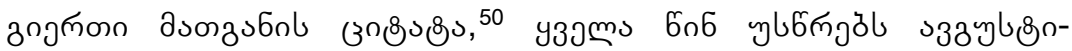

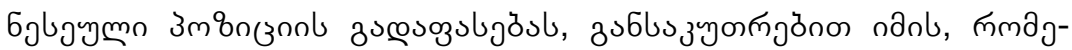

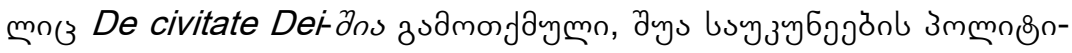

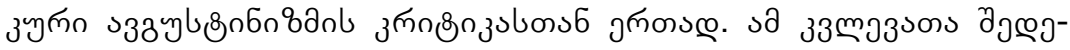

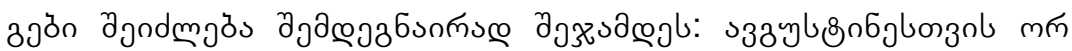

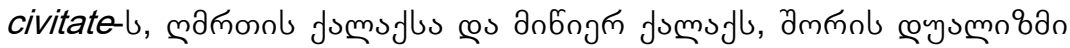

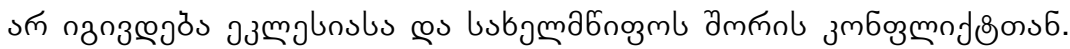

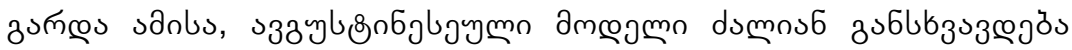

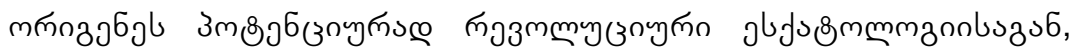

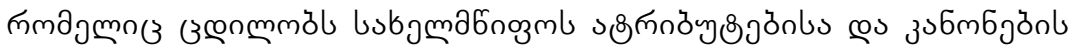

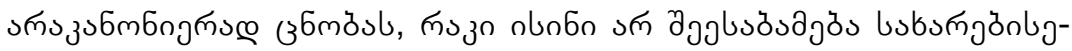

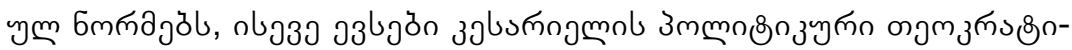

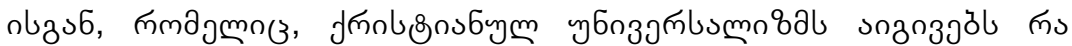

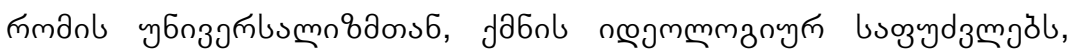

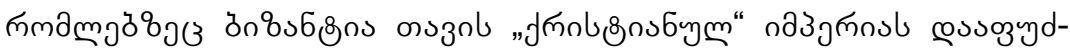

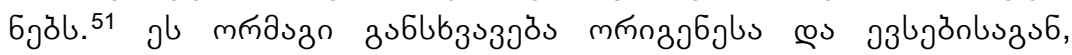

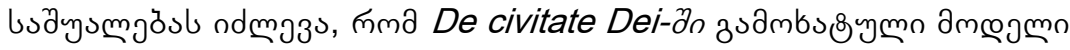

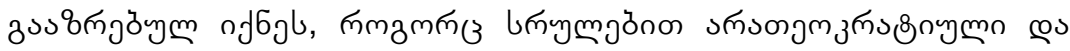

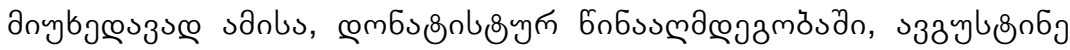

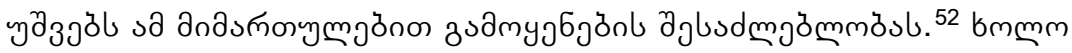

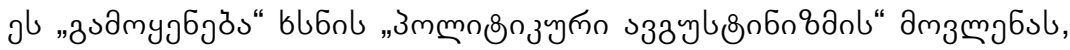

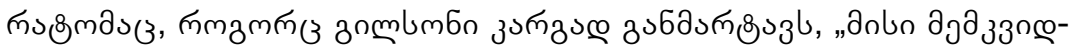

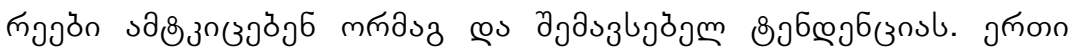

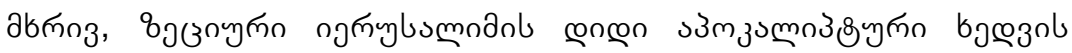

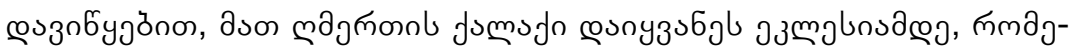

50 Niebuhr R., Christian Realism and Political Problems, New York, 1953; Gilson É., La città di Dio e i suoi problemi, Milano, 1959, 40-81; Cotta S., La città politica di sant'Agostino, Milano, 1960; Ratzinger J., Popolo e casa di Dio in sant'Agostino, Milano, 1978; Ratzinger J., L'unità delle nazioni. Una visione dei Padri della Chiesa, Brescia, 1973.

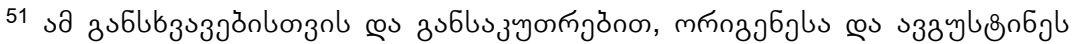

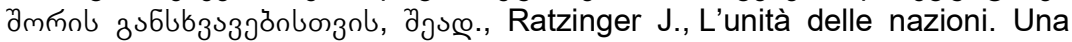
visione dei Padri della Chiesa, cit.

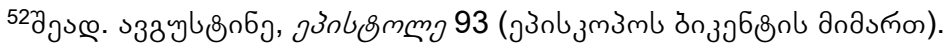




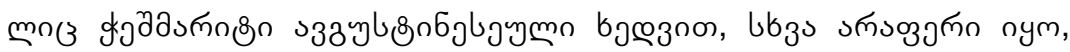

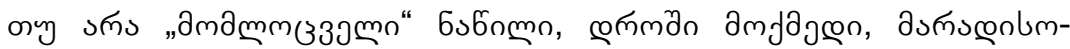

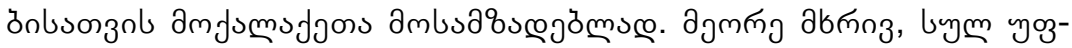

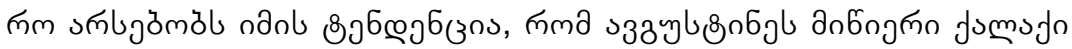

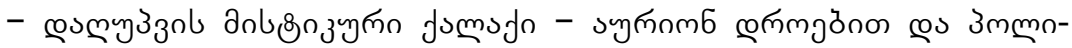

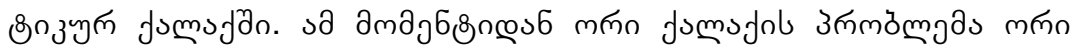

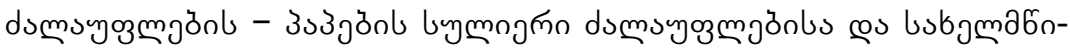

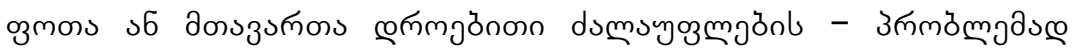

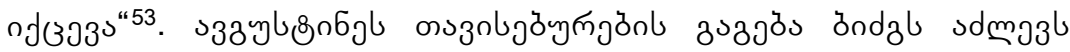

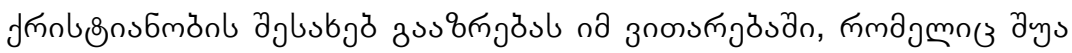

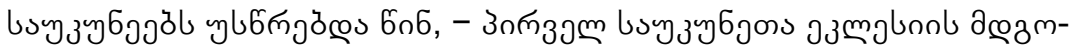

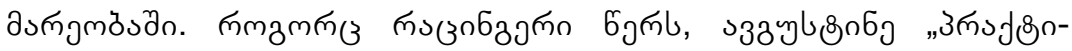

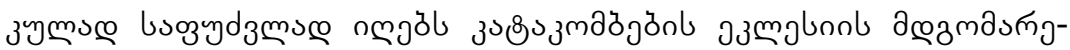

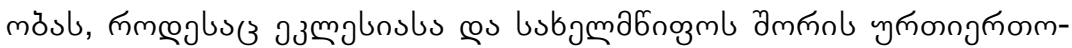

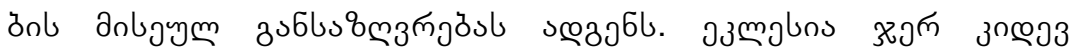

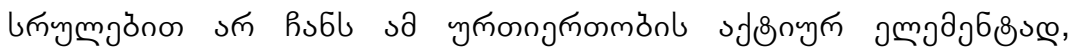

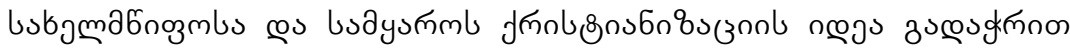

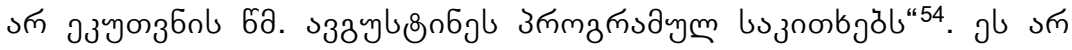

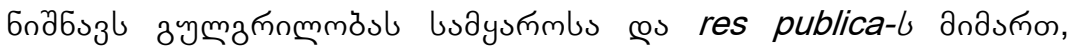

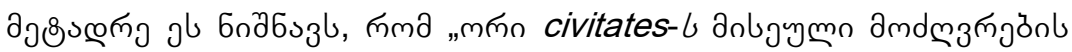

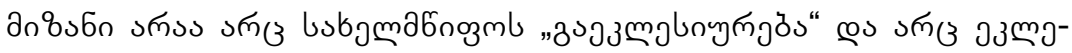

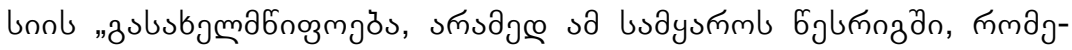

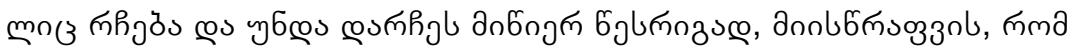

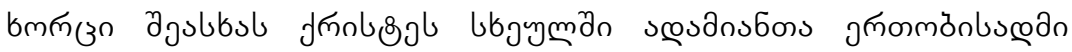

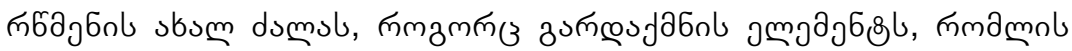

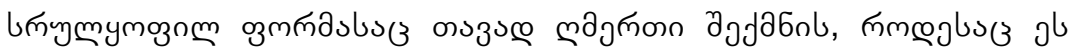

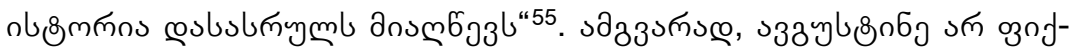

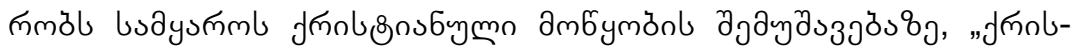

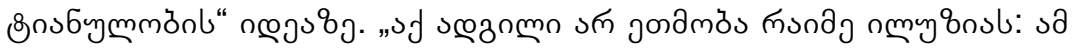

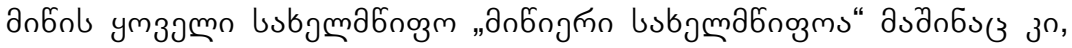

53 Gilson É., La città di Dio e i suoi problemi, cit., p. 81.

${ }^{54}$ Ratzinger J., Popolo e casa di Dio in sant'Agostino, Milano, 1978, 313.

55 Ratzinger J., L'unità delle nazioni. Una visione dei Padri della Chiesa, Brescia, 1973, 105. 
๓mলglus

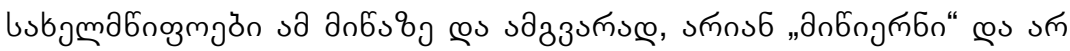

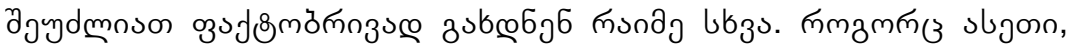

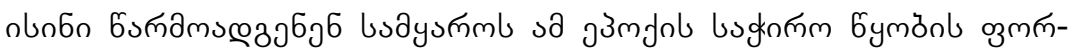
ة

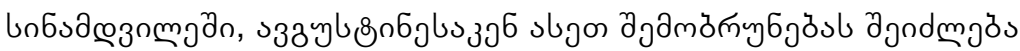

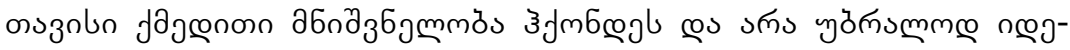

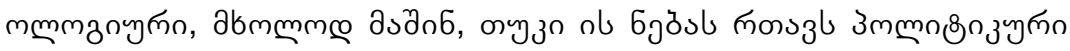

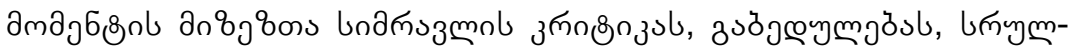

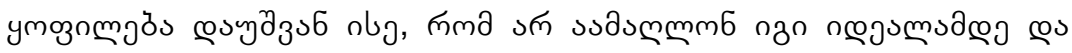

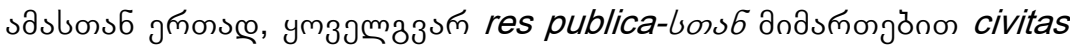

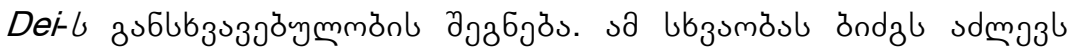

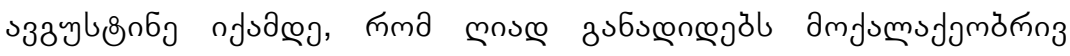

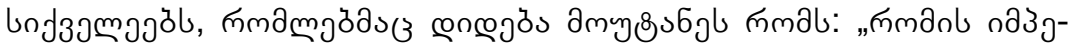

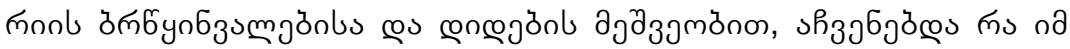

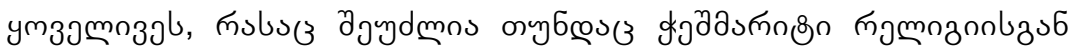

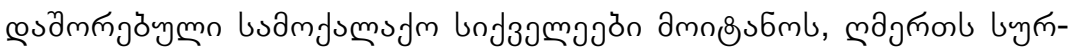

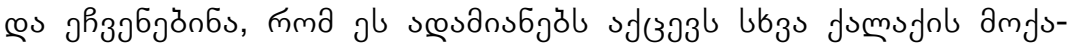

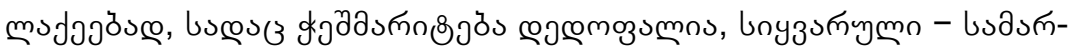

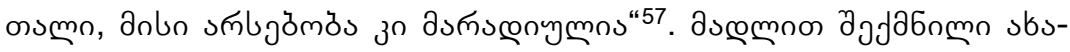

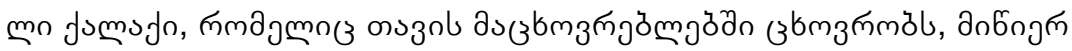

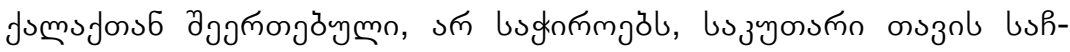

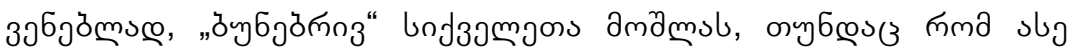

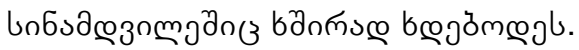

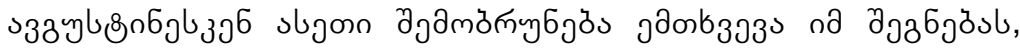

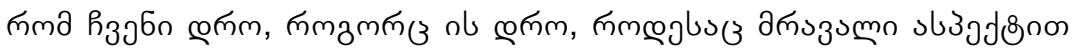

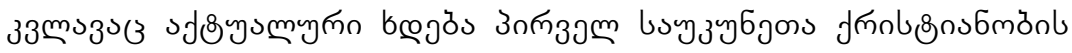

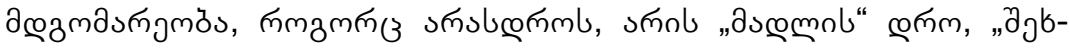

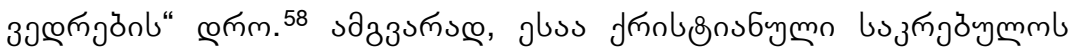

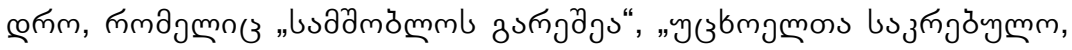

56 ก 37 o, 96.

58 Cfr. Bardy G., La conversione al cristianesimo nei primi secoli, Jaca Book, 1983. 


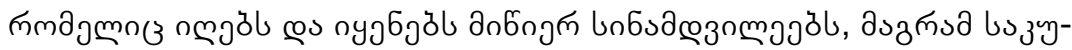

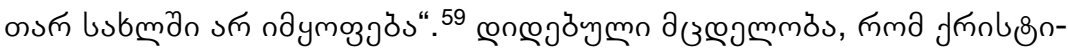

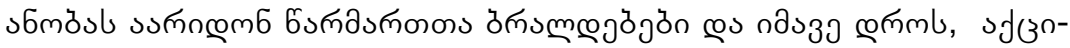

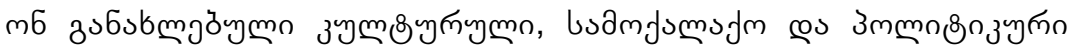

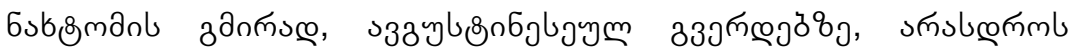

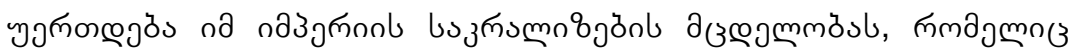

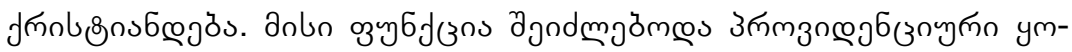

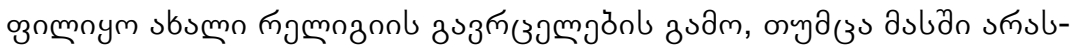

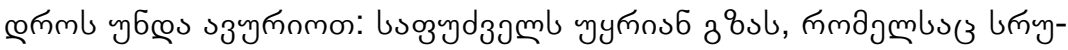

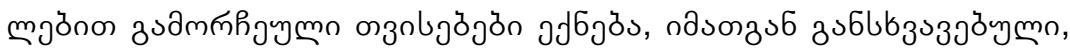

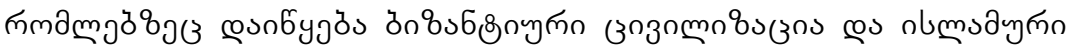

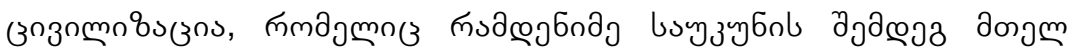

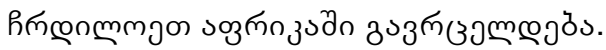

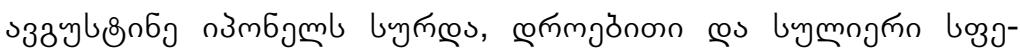

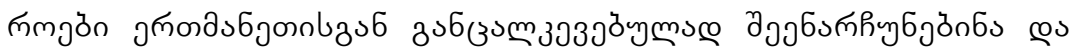

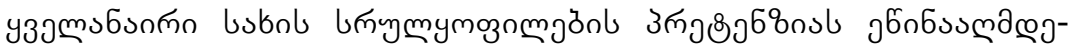

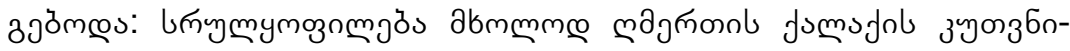

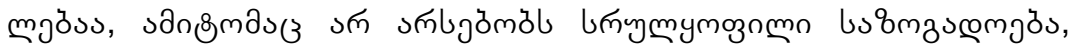

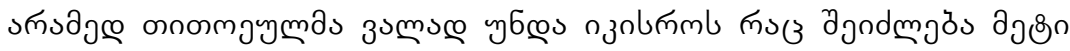

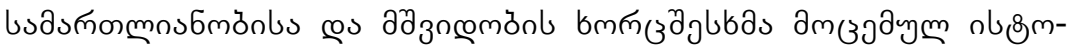

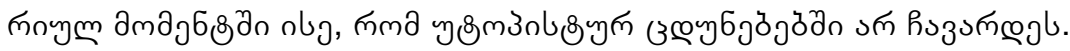

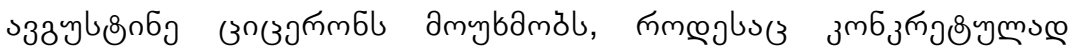

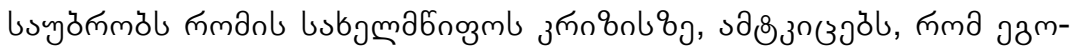

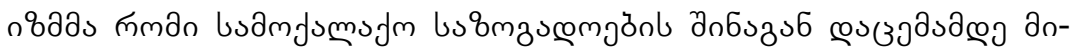

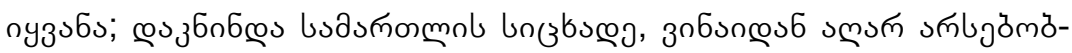

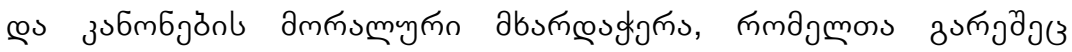

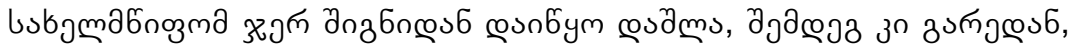

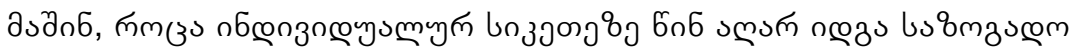

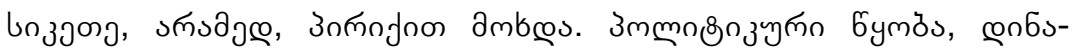

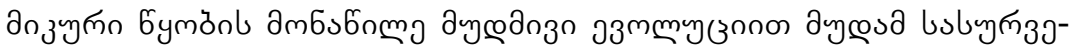

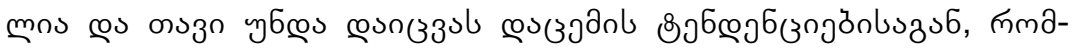

59 Ratzinger J., L'unità delle nazioni. Una visione dei Padri della Chiesa, Brescia, 1973, 107. 


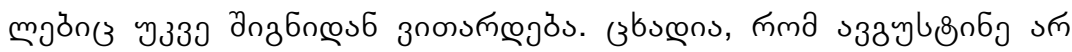

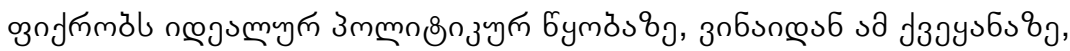

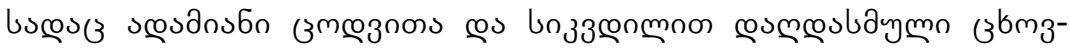

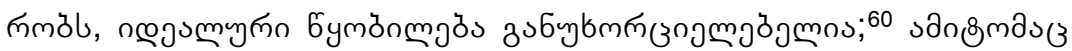

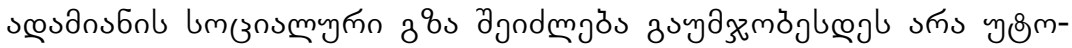

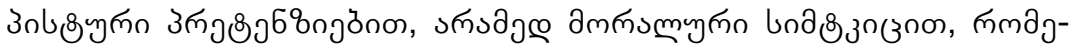

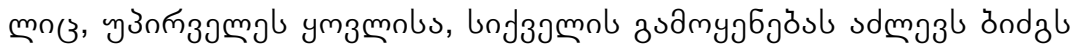

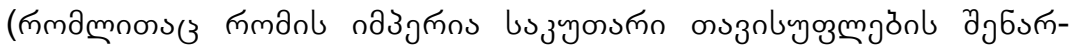

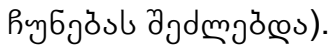

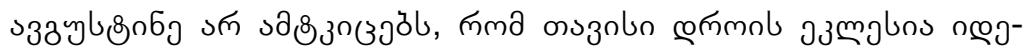

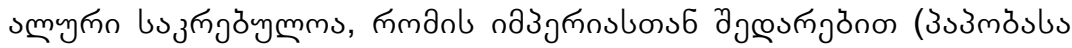

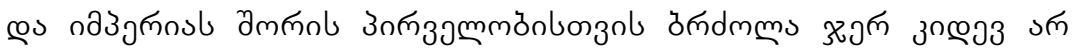

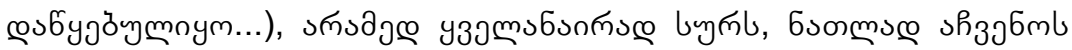

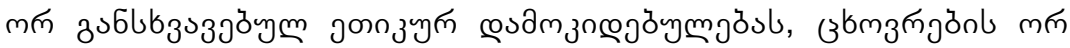

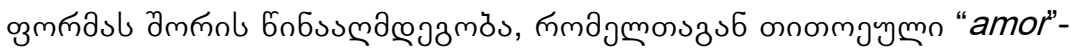

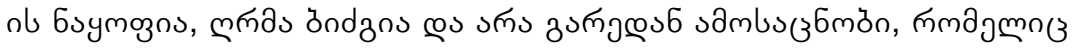

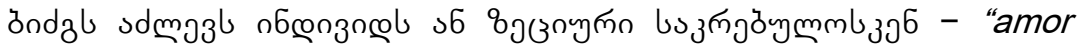

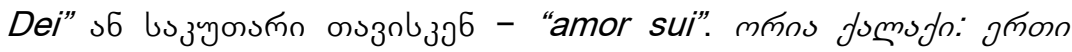

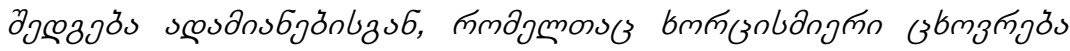

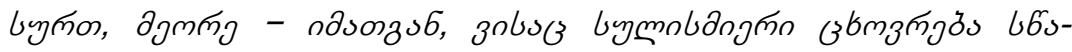

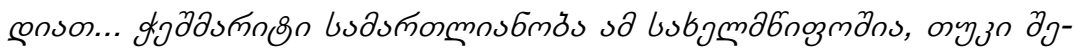

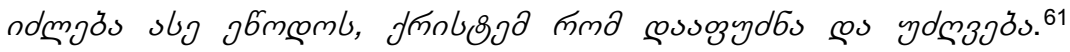

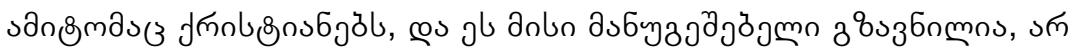

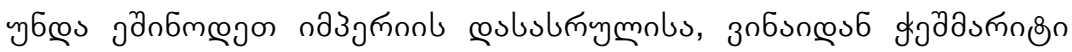

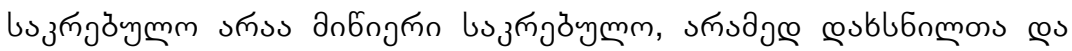

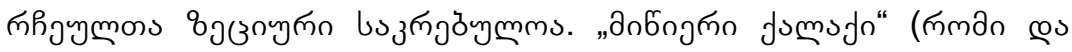

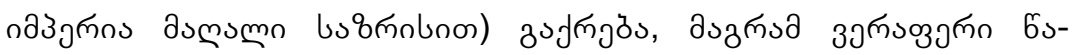

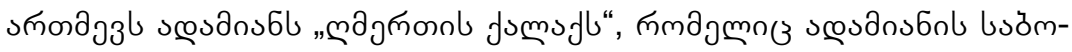

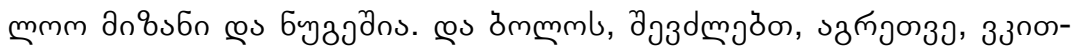

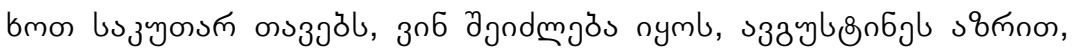

${ }^{60}$ Cfr. Dodaro R., I fondamenti teologici del pensiero politico agostiniano: le virtù teologali dello statista come ponte tra le due città, in: Etica \& Politica, IX, 2007, 38-45.

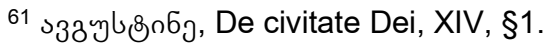




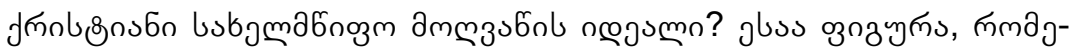

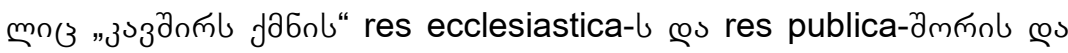

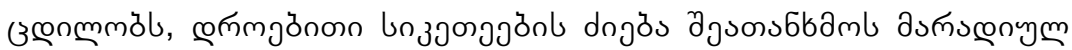

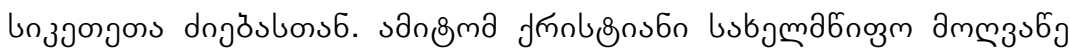

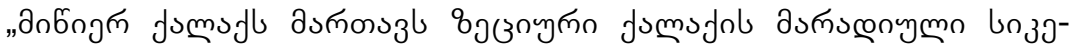

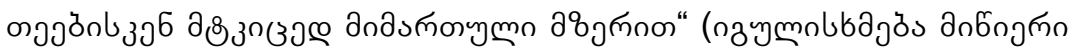

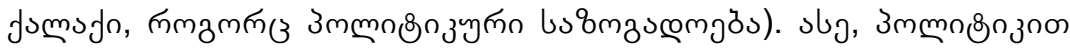

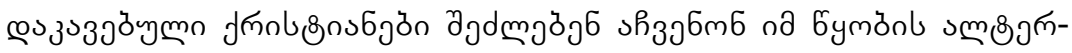

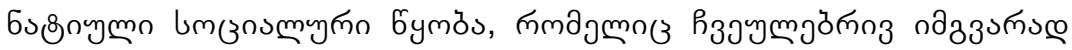

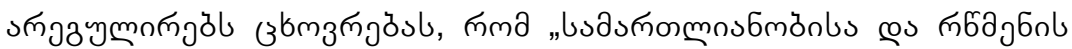

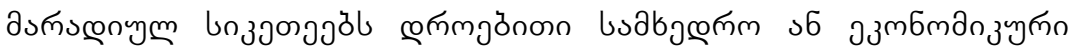

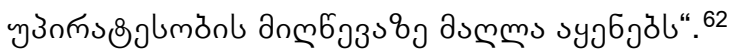

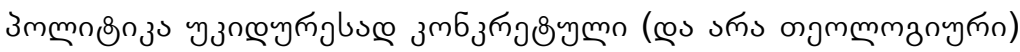

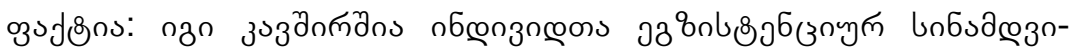

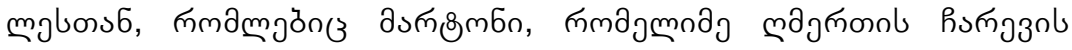

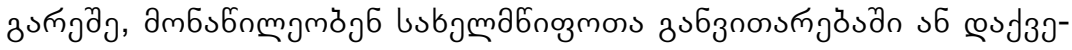

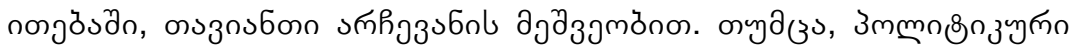

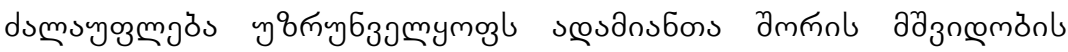

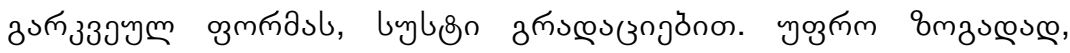

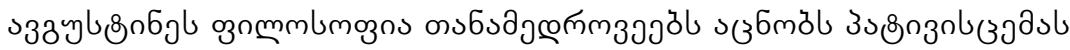

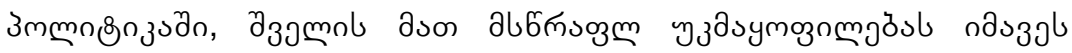

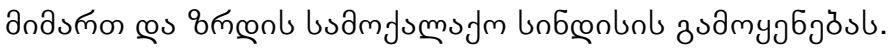

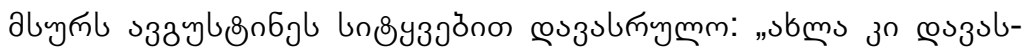

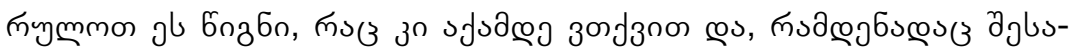

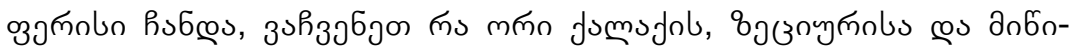

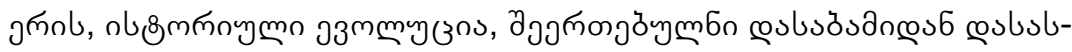

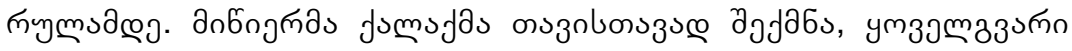

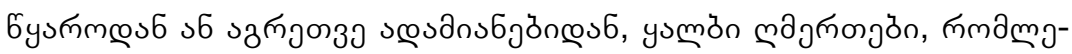

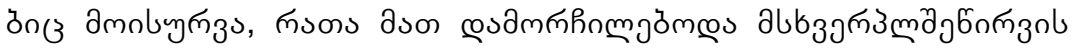

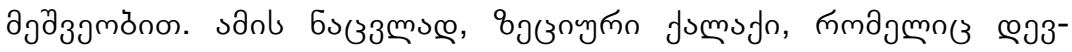

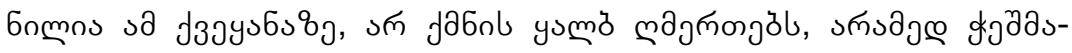

62 Cfr. Dodaro R., I fondamenti teologici del pensiero politico agostiniano: le virtù teologali dello statista come ponte tra le due città, in: Etica \& Politica, IX, 2007, 42, 48. 


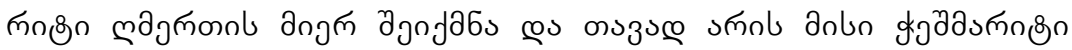

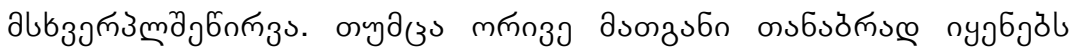

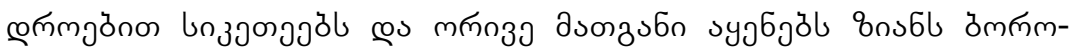

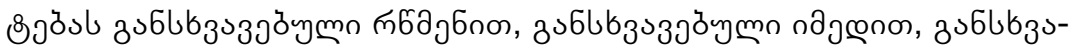

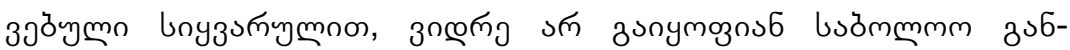

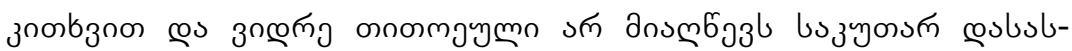

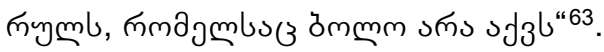

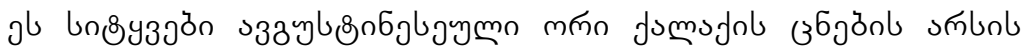

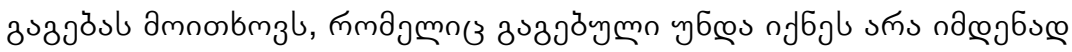

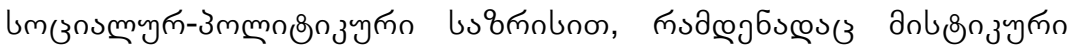

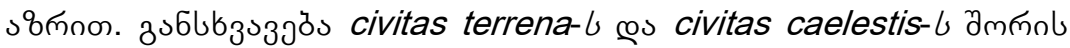

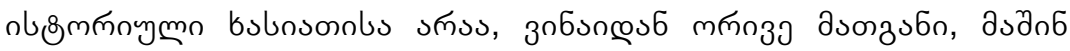

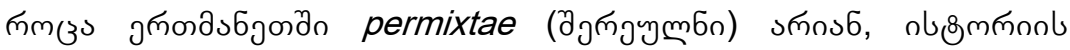

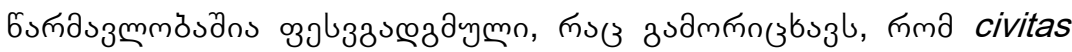

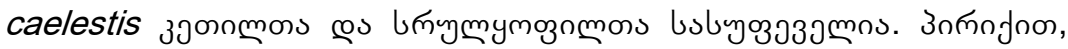

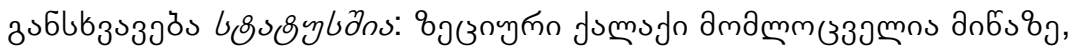

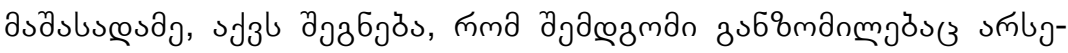

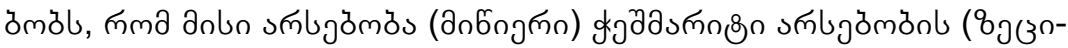

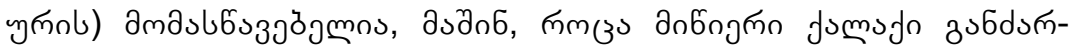

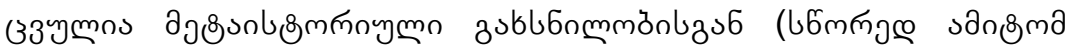

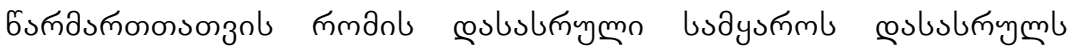
jant3วงว!).

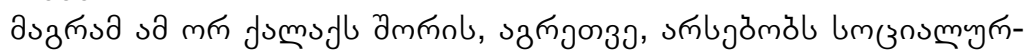

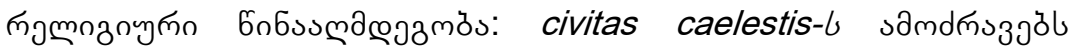

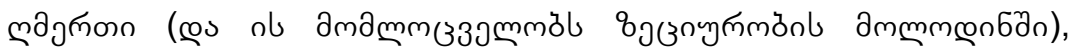

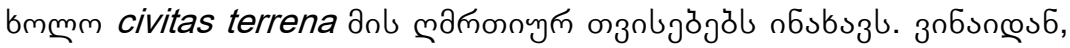

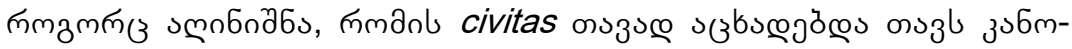

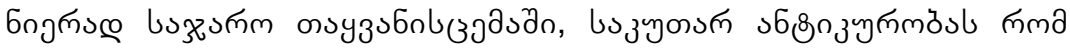

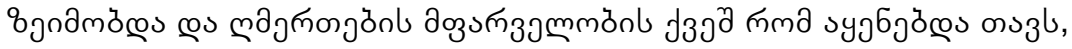

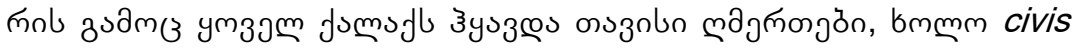

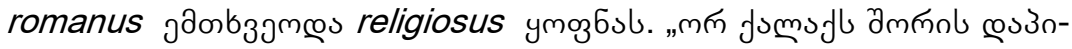

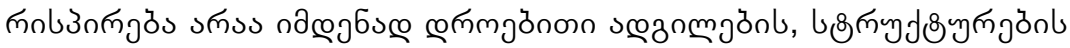

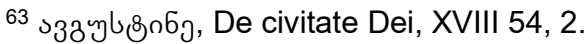




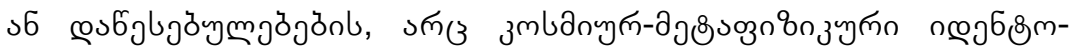

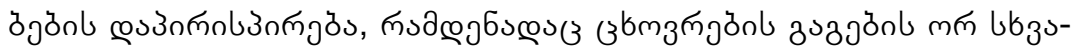

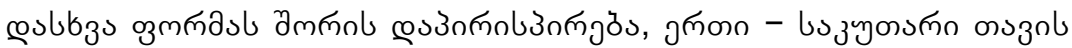

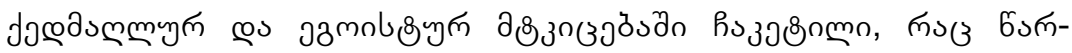

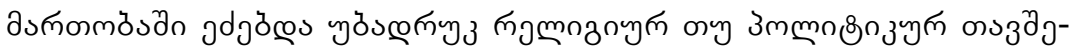

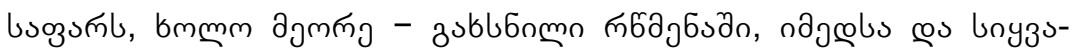

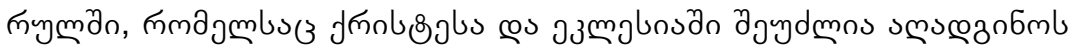

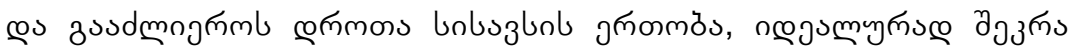

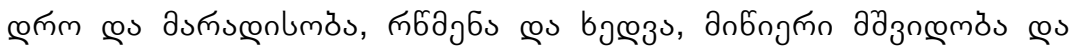

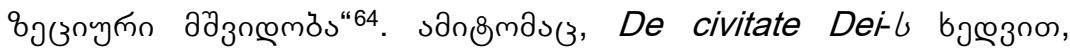

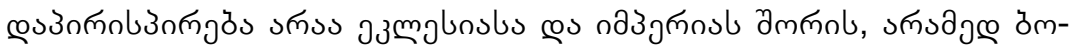

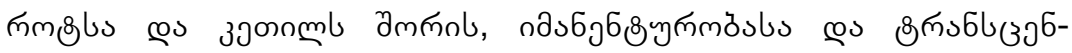

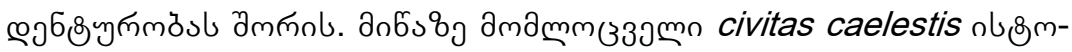

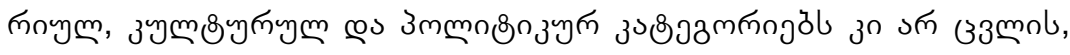

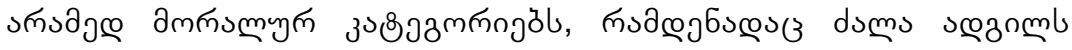

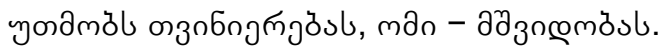

64 Luigi A., Introduzione a La Città di Dio, Rusconi, 1990, p. 37. 